\title{
Prosobranchia aus dem Litoral der karibischen Küste Kolumbiens
}

\author{
R. Kaufmann ${ }^{1}$ und K.-J. GötTing ${ }^{2}$ \\ Instituto Colombo-Alemán; Santa Marta, Colombia, \\ und \\ 2I. Zoologisches Institut der Universität Gießen; \\ Gießen/Labn, Deutschland (BRD)
}

\begin{abstract}
Prosobranchia from the littoral of the Caribbean coast of Colombia. 145 species of prosobranchs from the littoral zone of the Caribbean coast of Colombia, South America, are described and illustrated. The species belong to 79 genera of 44 families. Most of the species were collected at the coastal areas of Santa Marta, Cartagena and the peninsula Guajira. The biotopes considered are the rocky littoral zone, coral reefs, sand beaches and brackish water lagoons.
\end{abstract}

\section{EINLEITUNG}

Über die Molluskenfauna der südlichen Karibischen See ist noch wenig bekannt. Das gilt besonders für die Nordküste Kolumbiens, während für benachbarte Gebiete einige faunistische Bearbeitungen vorliegen (ArNow et al. 1963, BaKus 1968, BenThem Jutting 1927, Coomans 1958, Flores 1968, Jaume 1946, Jong \& Kristensen 1965, Lewis 1960, Olsson \& McGinty 1958, Rodriguez 1959, Work 1969). Die Lücken in unseren Kenntnissen zu schließen, ist nicht nur aus allgemein zoogeographischem Interesse wichtig, sondern vor allem im Hinblick auf den geplanten atlantischpazifischen Verbindungskanal auf Meeresniveau. Nur eine genaue Aufnahme des Artenbestandes auf beiden Seiten der mittelamerikanischen Landbrücke ermöglicht es, später die Auswirkungen der interozeanischen Verbindung zu ermitteln. Für solche Arbeiten ist das Instituto Colombo-Alemán in Santa Marta eine günstige Ausgangsbasis.

Das Material, das dieser Arbeit zugrunde liegt, wurde von einem der Autoren (KAUFMANN) in den Jahren 1964 bis 1969 aufgesammelt (Fundorte: Kartenskizzen der Abbildungen 146-148). Es umfaßt lebende Tiere und Gehäuse aus dem Angespül. Die Großbiotope Felslitoral, Korallenriff, Sandstrand und Brackwasserlagune wurden berücksichtigt.

Insgesamt wurden 145 Prosobranchier-Arten nachgewiesen. Sie sind im folgenden Text in systematischer Reihenfolge aufgeführt (in Anlehnung an WARMKE \& ABвoTT 1961). 
Im Textteil beziehen sich die Größenangaben auf das größte von uns gefundene Exemplar der Art, in den Abbildungen auf das jeweils abgebildete Gehäuse. Das Material befindet sich teils in der Sammlung des Instituto Colombo-Alemán, teils in den Privatsammlungen der Autoren.

\title{
VERZEICHNIS DER ARTEN \\ IN SYSTEMATISCHER REIHENFOLGE
}

\author{
Fissurellidae
}

\section{Hemitoma octoradiata GMELIN 1791}

(Abb. 1)

Länge $41 \mathrm{~mm}$, Breite $29 \mathrm{~mm}$. Schale derb, kegelförmig, vorn mit einer Rinne auf der Innenseite. Abdachung vorn konvex, hinten unterhalb des Apex konkav, dann gerade bis leicht konvex. Basis sehr variabel, jedoch vorn stets schmaler als hinten; Schalenrand innen fein gesägt. Skulptur aus 8 unverzweigten knotigen Radiärrippen, dazwischen feinere Rippen. Farbe von weiß über grau bis grünlich, Innenseite glänzend olivgrün bis purpurbraun. Schalen häufig mit Kalkalgen inkrustiert. Sehr häufig. Fundorte: Bahía Concha, Ensenada Bonitogordo, Isla de La Aguja, Ensenada de Granate, Pünta de Betín, Punta La Loma. Verbreitung: Südostflorida, Bahamas, Westindien, Nordküste Südamerikas.

\section{Diodora listeri OrbIGNX 1853}

(Abb. 2)

Länge $40,0 \mathrm{~mm}$, Breite 25,0 $\mathrm{mm}$. Gehäuse kegelförmig, mäßig erhoben. Abdachung variierend von konkav bis leicht konvex. Basis oval, Schalenrand mit paarigen Zähnchen. Die oft knotigen Radiärrippen alternierend stark und schwach, mit konzentrischen Leisten eine retikuläre Sǩsulptur bildend. Orificium groß, schlüssellochförmig, mit grauschwarzem Rand. Callus hinten abgestumpft, von blauschwarzer Linie begrenzt. Farbe außen weiß bis grau, gelegentlich mit dunklen Radiärstreifen. Innenseite weiß. Fundorte: Bahía Concha, Ensenada Bonitogordo, Ensenada de Granate, Punta de Betín. Verbreitung: Südliches Florida, Bermudas, Westindien, südlich bis Britisch Guayana.

\section{Diodora cayenensis LAMARCK 1822}

(Abb. 3)

Länge $18,0 \mathrm{~mm}$, Breite 12,0 mm. Gehäuse steil-kegelförmig. Abdachung vorn deutlich konkav, hinten gerade bis leicht konvex. Schalenrand fein gesägt. Jede 4. der feinen Radiärrippen stärker als die übrigen; von Zuwachslinien gekreuzt. Orificium unmittelbar vor dem Apex, schlüssellochförmig. Callus hinten abgestumpft. Schale weiß bis hellgraubraun. Innenseite weiß oder blauweiß. Fundorte: Buritaca, Bahía Concha, Punta de Betín. Verbreitung: Südöstliche USA bis Brasilien. 


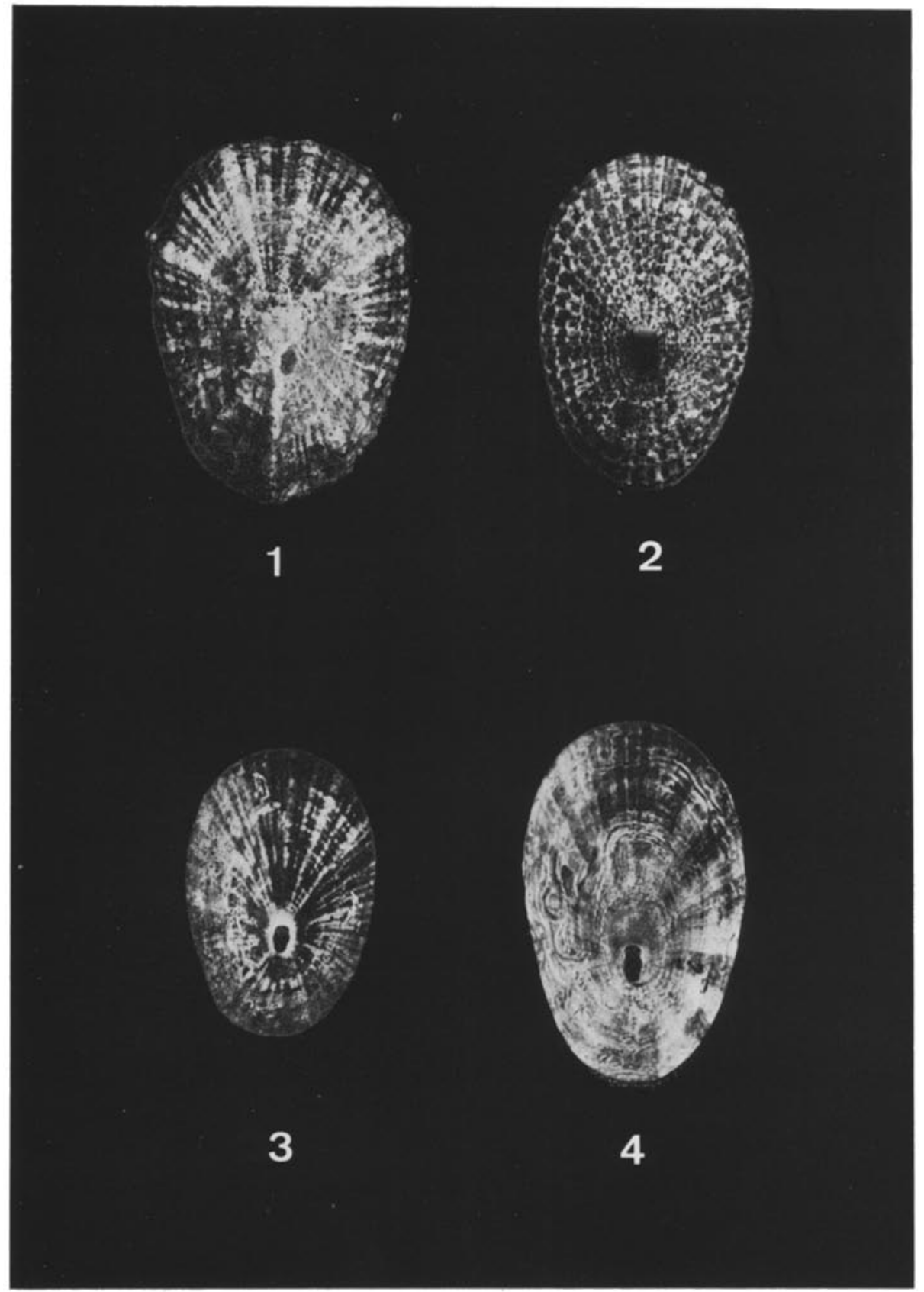

Abb. 1-4: Fissurellidae. 1: Hemitoma octoradiata (größter Durchmesser $24 \mathrm{~mm}$ ), 2: Diodora listeri $(22 \mathrm{~mm}), 3$ : Diodora cayenensis $(18 \mathrm{~mm}), 4$ : Diodora viridula $(24 \mathrm{~mm})$ 


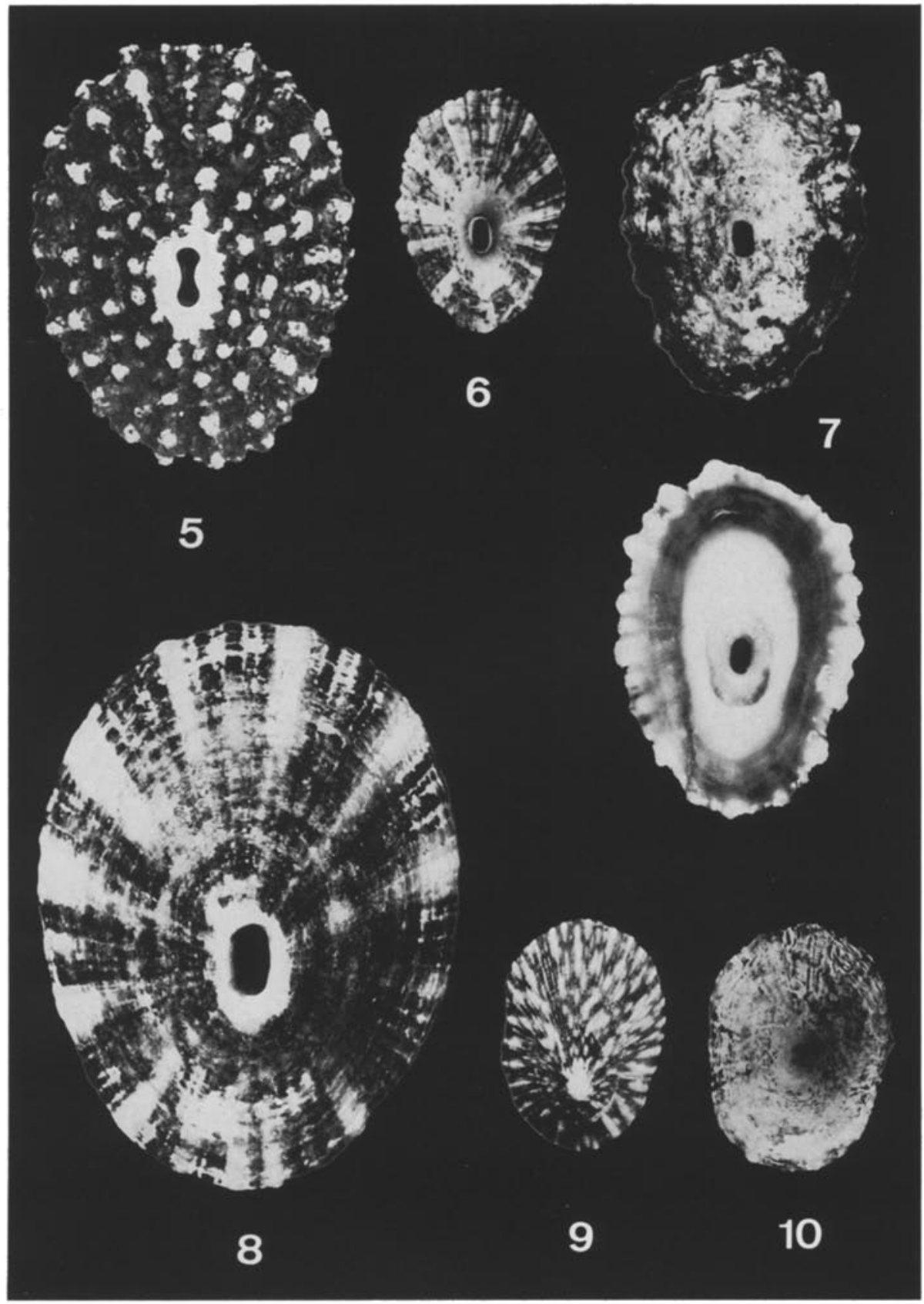

Abb. 5-10: Fissurellidae, Acmaeidae. 5: Fissurella nodosa (größter Durchmesser $28 \mathrm{~mm}$ ), 6: Fissurella barbadensis $(16 \mathrm{~mm}), 7$; Fissurella angusta $(23 \mathrm{~mm}), 8$ : Fissurella nimbosa $(37 \mathrm{~mm}), 9:$ Acmaed antillarum $(15 \mathrm{~mm}), 10:$ Acmaea pustulata $(15 \mathrm{~mm})$ 


\section{Diodora viridula LAMARCK 1822}

(Abb. 4)

Länge $23,7 \mathrm{~mm}$, Breite $14,5 \mathrm{~mm}$. Gehäuse konisch erhoben, vor dem Apex niedriger. Abdachung vorn gerade oder leicht konkav, hinten konvex. Apex vor der Mitte. Schalenrand gezähnt. Zwischen den 18-20 radiären Hauptrippen jeweils 3 feinere Rippen, deren mittlere dicker ist als die beiden anderen. Orificium unmittelbar vor dem Apex, schlüssellochförmig, häufig mit 2 seitlichen Zähnchen, blauschwarz umrandet. Callus hinten abgestumptt, mit feinen Radiärleisten vorn und seitlich, von einem blauschwarzen Rand umgeben. Hauptrippen weiß oder hellgrau, Sekundärrippen grüngrau. Innenseite grüngrau oder bläulich. Fundorte: Bahía Concha, Punta de Betín. Verbreitung: Florida, Bahamas, Golf von Mexiko, Antillen, südlich bis Trinidad.

\section{Fissurella nodosa Born 1778}

(Abb. 5)

Länge $31,0 \mathrm{~mm}$, Breite $22,0 \mathrm{~mm}$. Gehäuse steil-kegelförmig. Abdachung konvex. Basis oval. Skulptur aus 20-22 stark knotigen Radiärrippen. Orificium länglich, in der Mitte etwas verengt. Callus oval. Schale weiß, aschgrau oder braun. Innenseite weiß. In der Gezeitenzone. Fundorte: Cabo de La Vela, Bahía Concha, Punta de Betín. Verbreitung: Florida Keys, Westindien, südliches Mexiko, Venezuela.

\section{Fissurella barbadensis GMELIN 1791}

(Abb. 6)

Länge $27,5 \mathrm{~mm}$, Breite $17,0 \mathrm{~mm}$. Gehäuse kegelförmig, mäßig erhoben. Abdachung konvex. Basis länglich-oval, am Vorderende schmaler. Schalenrand kräftig gezähnt. Zahlreiche radiäre Rippen. Orificium oval, in der Mitte schwach verengt. Callus oval, hinten leicht abgestumpft, umgeben von einem grünen Rand und einer rotbraunen Begrenzungslinie. Schale außen aschgrau bis gelbbraun, juvenile Schalen mit purpurbraunen Flecken. Innenseite mit breitem weißem Band zwischen Callus und grüner Randzone. Fundorte: Bahía Concha, Punta de Betín. Verbreitung: Südostflorida, Bermudas, Westindien.

\section{Fissurella angusta GMELIN 1791}

(Abb. 7)

Länge $27,0 \mathrm{~mm}$, Breite $19,0 \mathrm{~mm}$. Gehäuse flach-kegelförmig. Abdachung leicht konvex. Basis unregelmäßig oval, vorn zugespitzt. Skulptur aus 9 stärkeren, leicht knotigen Radiärrippen, dazwischen feinere Rippen in variierender Anzahl. Orificium eng, oval. Callus hinten abgestumpf, hellbraun. Außenseite rötlichbraun, die Hauptrippen weiß. Innenseite mit einem weißen Band zwischen Callus und bläulichgrüner Randzone. Fundorte: Bahía Concha, Ensenada de Granate, Punta de Betín. Verbreitung: Lower Florida Keys, Bahamas, Westindien bis Britisch Guayana.

\section{Fissurella nimbosa LINNÉ 1758}

(Abb. 8)

Länge 48,0 mm, Breite $33,0 \mathrm{~mm}$. Gehäuse steil-kegelförmig. Abdachung gerade bis leicht konvex. Basis oval, vorn etwas schmaler. Schalenrand leicht gezähnt. Zahl- 
reiche feine, flache Radiärrippen. Orificium groß, länglich, in der Mitte etwas verengt. Callus oval. Außenseite mit alternierenden purpurbraunen und lederfarbenen Radiärstreifen. Innenseite hellgrün, um den Callus die Färbung am sattesten. Fundorte: Cabo de La Vela, Bahía Concha, Ensenada Bonitogordo, Ensenada de Granate, Punta de Betín, Punta La Loma. Verbreitung: Puerto Rico, südliches Westindien, Nordküste Südamerikas.

\section{Acmaeidae}

\section{Acmaea antillarum Sowerby 1831}

(Abb. 9)

Länge 24,0 mm, Breite 19,0 mm. Gehäuse flach kappenförmig, Schale dünn. Abdachung leicht konvex. Basis oval, vorn schmaler. Zahlreiche feine Radiärrippen. Schalenrand fein gezähnt. Außenseite grauweiß mit zahlreichen radiären bräunlichen Flekken oder Streifen unterschiedlicher Ausdehnung. Innenseite glänzend blauweiß mit hellbraunem Callus. Innenrand braun mit schokoladenbraunen, radiären Streifen und Winkeln. Fundorte: Bahía Concha, Ensenada de Granate, Punta de Betín, Bocagrande. Verbreitung: Südliches Florida, Bermudas, Westindien.

\section{Acmaea pustulata Helbling 1779}

(Abb. 10)

Länge $19,0 \mathrm{~mm}$, Breite $15,0 \mathrm{~mm}$. Gehäuse kappenförmig, mäßig erhoben. Basis gerundet rechteckig. Skulptur aus zahlreichen, verschieden starken Radiärrippen und feinen Wachstumslinien. Außenseite weiß mit orangeroten, radiären Flecken oder Streifen. Innenseite glänzendweiß. Callus hellgelb. Fundorte: Bahía Concha, Ensenada de Granate. Verbreitung: Südöstliches Florida, Bermudas, Westindien.

\section{Trochidae}

\section{Livona pica LINNÉ 1758}

(Abb. 11)

Höhe $72,0 \mathrm{~mm}$, Breite $86,0 \mathrm{~mm}$. Schale dick und schwer. Gewinde konisch; 5 geschulterte Umgänge. Nabel rund, sehr tief, bei ausgewachsenen Exemplaren teilweise bedeckt durch zahnförmige Schwiele am Parietalcallus. Mündung rund, innen mit Perlmutterglanz. Oberfläche runzelig durch unregelmäßig angeordnete Knötchen. Auf der Wölbung des letzten Umganges vielfach flache Spiralleisten. Wachstumslinien sehr dicht aufeinanderfolgend. Auf grauweißem Grund purpurne bis schwarze Flecken unterschiedlicher Form und Größe, oft in Bändern angeordnet. Operculum nicht verkalkt, rund, dunkelbraun. Sehr häufig im Litoral. Wird von Fischern gegessen und soll aphrodisische Wirkung haben. Fundorte: Bahía Concha, Ensenada Bonitogordo, Isla de La Aguja, Ensenada de Granate, zwischen Punta de Granate und Punta Las Minas, Punta de Betín, Morro de Gaira. Verbreitung: Westindien. 


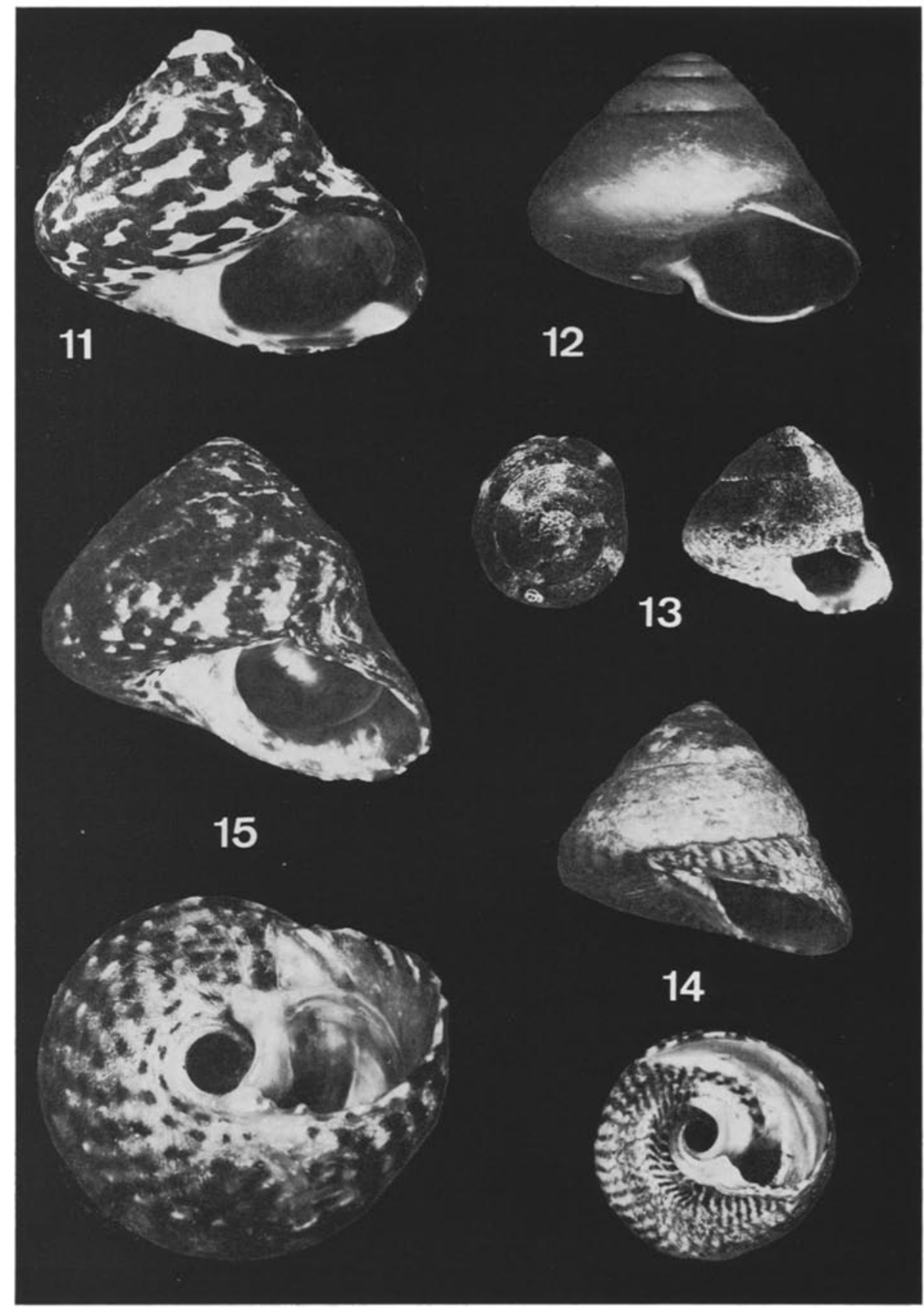

Abb. 11-15: Trochidae. 11: Livona pica (40 mm hoch), 12: Gaza superba (33 mm), 13: Tegula fasciata $(6,5 \mathrm{~mm}), 14:$ Tegula excavata $(10 \mathrm{~mm}), 15:$ Tegula viridula $(15 \mathrm{~mm})$ 


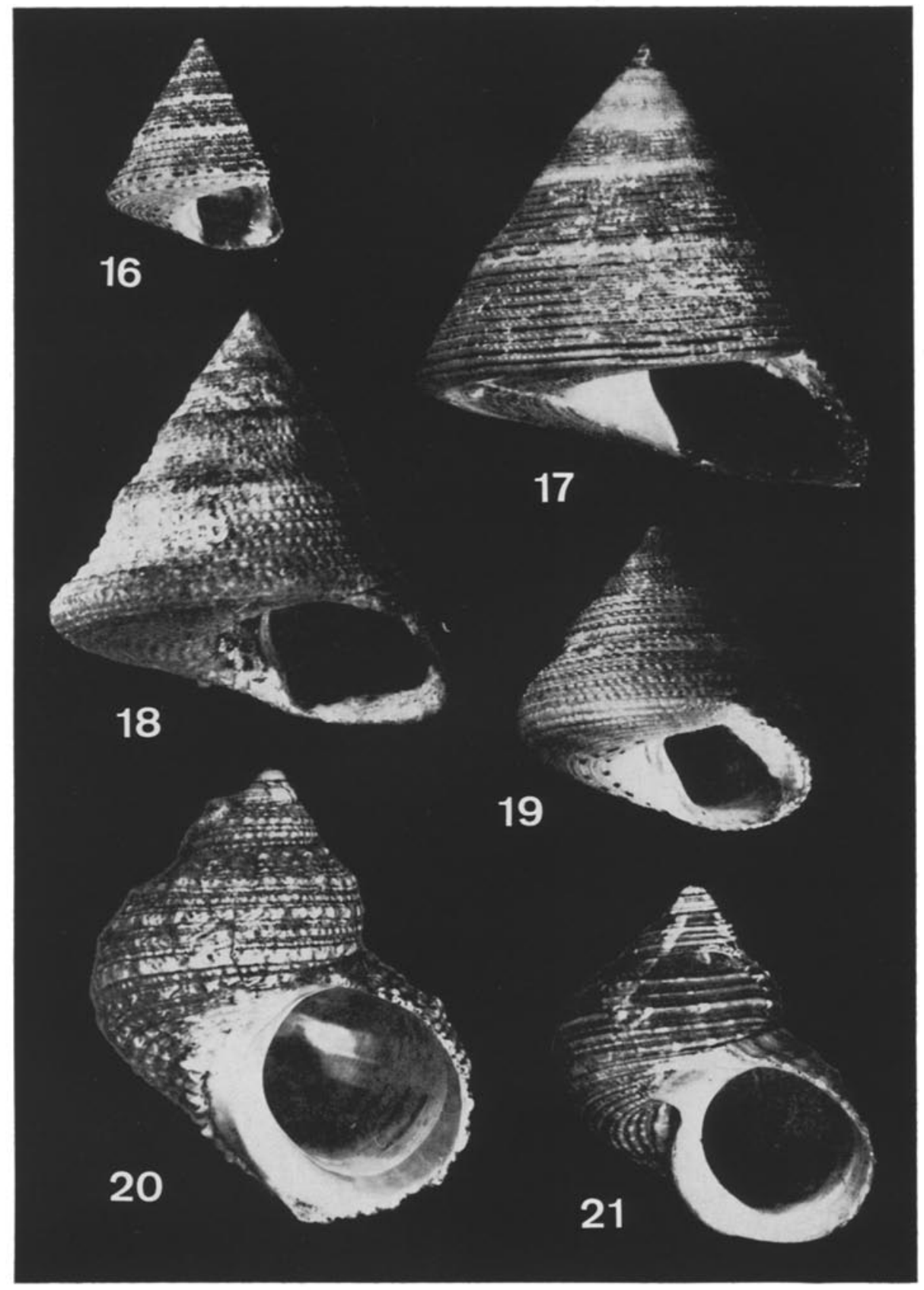

Abb. 16-21: Trodidae, Turbinidae. 16: Calliostoma pulchrum $(9 \mathrm{~mm}$ hoch), 17: Calliostoma javanicum (27 mm), 18: Calliostoma jujubinum $(16 \mathrm{~mm})$, 19: Calliostoma euglyptum $(11,5 \mathrm{~mm})$, 20: Turbo castanea $(30 \mathrm{~mm})$, 21: Turbo cailletii $(23 \mathrm{~mm})$ 


\section{Gaza superba DALL 1881}

(Abb. 12)

Höhe $36,5 \mathrm{~mm}$, Breite $45,0 \mathrm{~mm}$. Schale leicht. Gewinde konisch, abgestuft. Apex bei allen Exemplaren abgebrochen. Naht tief. 8 mäßig gewölbte Umgänge. Nabel durch perlmuttrigen Callus bis auf eine enge Offnung am inneren Mündungsrand bedeckt. Mündung subelliptisch, innen mit Perlmutterglanz; Außenlippe wulstartig verdickt. Skulptur aus feinen, schrägen Wachstumslinien und mikroskopischen Spirallinien. Die ersten Umgänge rosa bis violett irisierend, übrige Schale grünlich-elfenbeinfarben. Operculum dünn, rund und hornfarben. In tieferem Wasser. Fundorte: Schelf vor Santa Marta (Oregon II - Station 269), gelegentlich im Spülsaum. Verbreitung: Golf von Mexiko, Westindien.

\section{Tegula fasciata BORN 1778}

(Abb. 13)

Höhe $8,0 \mathrm{~mm}$, Breite $10,5 \mathrm{~mm}$. Gewinde konisch. Basis leicht konvex. 6-8 gerundete Umgänge. Nabel eng und tief. Mündung rund, mit 2 Zähnchen an der Basis der Columella. Auf Umgängen und Basis feine Spirallinien. Gehäuse rötlich- bis dunkelolivbraun, mit unregelmäßigen dunkleren Flecken auf hellerem Grund. Operculum nicht verkalkt, rund und hornfarben. Unter Steinen im Flachwasser. Fundorte: Bahía Concha, Ensenada Bonitogordo, Ensenada de Granate. Verbreitung: Südöstliches Florida, Westindien.

\section{Tegula excavata LAMARck 1822}

(Abb. 14)

Höhe $12,0 \mathrm{~mm}$, Breite $16,0 \mathrm{~mm}$. Gewinde konisch, Naht wenig eingesenkt. Die 5 Umgänge mäßig gerundet, der letzte stumpf gekielt. Basis konkav. Nabel tief, umgeben von einem glatten, grünirisierenden Ring. Mündung in Form eines zur Columella geneigten Parallelogramms, innen mit grünlichem Perlmutterglanz. Außenlippe nicht verdickt, Innenlippe mit zahnartigem Vorsprung. Skulptur aus feinen Spirallinien und schrägen Wachstumslinien. Schale grüngrau mit unregelmäßigen purpurbraunen Flekken. Operculum durchscheinend dünn, rund und honigfarben. Sehr häufig im Felslitoral. Fundorte: Ensenada Bonitogordo, Isla de La Aguja, Ensenada de Granate, Punta de Betín, Morro de Gaira. Verbreitung: Lower Florida Keys, Westindien.

\section{Tegula viridula GMELIN 1791}

(Abb. 15)

Höhe 18,0 mm, Breite $21,0 \mathrm{~mm}$. Gehäuse konisch. Die 5 Umgänge gewölbt, der letzte unterhalb der Naht deutlich konkav, so daß das Gewinde abgestuft erscheint. Nabel rund, weit und tief. Mündung rundlich, zur Columella hin ausgebuchtet; innen mit flachen Spirallinien und grünlichem Perlmutterglanz. Außenlippe mäßig verdickt. An der Basis der Columella 2-3 Zähnchen. Umgänge und Basis mit flachen, spiraligen Knotenreihen und feinen, schrägen Wachstumslinien. Schale olivgrün bis purpurbraun, manchmal mit alternierenden hellen und dunklen Bändern. Fundorte: nördlich Punta de Papare, Bocagrande. Verbreitung: Mittelamerika, Nordküste Südamerikas bis Brasilien. 


\section{Calliostoma pulchrum C. B. ADAms 1850}

(Abb. 16)

Höhe $9,0 \mathrm{~mm}$, Breite $7,5 \mathrm{~mm}$. Gewinde spitz-konisch. Naht wenig deutlich. Die 7-10 Umgänge gerade, mit basalem, wulstförmigem Kiel. Ungenabelt. Mündung in Form eines zur Columella geneigten Parallelogramms. Außenlippe nicht verdickt; Columella verdickt, weiß. Feine Spiralreihen kleiner Knötchen auf der Basis und den Umgängen, die Knötchen am Kiel der Umgänge etwas gröber. Schale rötlichbraun, mit einer Reihe alternierender weißer und rotbrauner Flecken auf dem Kiel und im zentralen Bereich der Basis. Fundort: Bahía Concha. Verbreitung: North Carolina, Florida, Golf von Mexiko, Karibisches Meer.

\section{Calliostoma javanicum LaMarck 1822}

(Abb. 17)

Höhe $30,0 \mathrm{~mm}$, Breite $28,0 \mathrm{~mm}$. Gehäuse spitz-konisch. Naht undeutlich. Die 9-10 Umgänge flach, nur durch einen scharfen Kiel voneinander abgesetzt. Nabel weit und tief, zur Basis der Columella trichterförmig erweitert. Mündung in Form eines zur Columella geneigten Parallelogramms. Außenlippe nicht verdickt, am Rand gezähnt. Columella verdickt, nach rechts gekurvt, weiß. Auf Umgängen und Basis zahlreiche Spiralreihen feiner, gleichgroßer Knötchen. Die Basis einwärts vom Kiel auf etwa 1/3 ihres Radius ohne Knötchenreihen. Schale gelblichbraun mit feinen rotbraunen Spirallinien zwischen den Knötchenreihen. Fundort: Islas del Rosario. Verbreitung: Südflorida, Bahamas, Westindien.

\section{Calliostoma jujubinum GMELIN 1791}

(Abb. 18)

Höhe $16,0 \mathrm{~mm}$, Breite $16,0 \mathrm{~mm}$. Gehäuse spitz-konisch. Naht undeutlich. 9-10 leicht gewölbte Umgänge mit gerundetem Kiel. Nabel eng und tief, von einem Knötchenband begrenzt. Mündung in Form eines zur Columella geneigten Parallelogramms. Columella mit scharfer Falte, leicht gekurvt, an der Basis einen Zahn tragend. Auf Umgängen und Basis zahlreiche spiralige Knotenreihen, die Knötchen der Basis zum Nabel hin größer werdend. Schale gelb- bis rötlichbraun. Fundort: Ensenada de Granate. Verbreitung: Bahamas, Golf von Mexiko, Westindien.

\section{Calliostoma euglyptum A. Adams 1854}

(Abb. 19)

Höhe 12,0 mm, Breite $11,0 \mathrm{~mm}$. Gehäuse spitz-konisch. Naht deutlich. 7 leicht bauchige Umgänge. Ungenabelt. Mündung fast quadratisch. Außenlippe nicht verdickt. Columella verdickt, leicht gekurvt, weiß. Auf Umgängen und Basis zahlreiche Spiralreihen feiner Knötchen. Apicale Umgänge grüngrau, die übrigen rötlichbraun bis dunkelbraun, gelegentlich mit weißen und dunkelrotbraunen Flecken. Auf Basis mehrere Spiralreihen feiner rotbrauner Striche. Fundorte: Bahía Concha, Ensenada Bonitogordo. Verbreitung: Ostküste der USA von North Carolina nach Süden, Golf von Mexiko bis Yucatán. 


\section{Turbinidae}

\section{Turbo castanea GMELIN 1791}

(Abb. 20)

Höhe $33,5 \mathrm{~mm}$, Breite $27,0 \mathrm{~mm}$. Gewinde konisch. Die 5 gerundeten Umgänge, besonders der letzte, deutlich gestuft. Nabel durch Callus vollständig bedeckt. Mündung rund, innen mit Perlmutterglanz. Außenlippe nicht verdickt. Columella verdickt, gekurvt, weiß und gegen Basis durch eine Furche abgesetzt. Skulptur aus Spiralreihen verschieden starker Knoten. Die Knoten unterhalb der Naht und auf der Schulter des letzten Umganges oft lamellös. Auf Basis Spiralreihen feiner Knötchen. Schale braun oder graubraun, gelegentlich mit rotbraunen Flecken. Fundorte: Bahía Concha, Ensenada de Granate, Islas del Rosario. Verbreitung: von North Carolina bis Florida, Texas, Westindien. Bei einem Exemplar von Bahía Concha handelt es sich nach Аввотт (briefliche Mitteilung) um eine ungewöhnliche Farbvariante: Unterhalb der Schulter findet sich auf olivbraunem Grund ein rostrotes Spiralband.

\section{Turbo cailletii FISCHER \& BERNARDI 1857}

(Abb. 21)

Höhe 27,0 mm, Breite 22,5 mm. Gehäuse konisch. Naht tief eingesenkt. Die $5 \mathrm{Um}-$ gänge bauchig. Nabel eng, teilweise vom Columellarcallus bedeckt. Mündung rund. Außenlippe nicht verdickt. Columella dick, gekurvt, zur Basis schildartig verbreitert. Auf den Umgängen 5-6 glatte Spiralleisten, mit feineren Spirallinien in den Zwischenräumen und schrägen Wachstumslinien. Schale gelbbraun bis braun, mit rötlichbraunen Flecken oder Bändern. Fundort: Islas del Rosario.

\section{Astraea caelata GMeLin 1791}

(Abb. 22)

Höhe $82,0 \mathrm{~mm}$, Breite $72,0 \mathrm{~mm}$. Schale dick und schwer. Gewinde konisch. 5-6 Umgänge. Ungenabelt. Mündung oval. Außenlippe nicht verdickt. Columella verdickt, stark gekurvt, glasigweiß. Skulptur aus kräftigen Spiralwïlsten, die von schrägen Reihen offener, schuppenförmiger Stacheln gekreuzt werden. Basis mit 5 dicht liegenden Spiralreihen nach innen kleiner werdender, schuppiger Stacheln. Das der Mündung anliegende Drittel der Basis callusartig glatt. Schale grau, grünlich oder rötlichgelbbraun. Operculum kalkig, dick, auf der stark gewölbten Außenseite pustulös. Häufig mit Kalkalgen inkrustiert. Im Flachwasserbereich zwischen Steinen und Korallenblöcken. Fundorte: Bahía Concha, Ensenada de Granate, Punta de Betín, Ancon. Verbreitung: Südöstliches Florida, Westindien.

\section{Astraea tuber LINNÉ 1758}

(Abb. 23)

Höhe $34,0 \mathrm{~mm}$, Breite $37,0 \mathrm{~mm}$. Gehäuse konisch. Naht mäßig deutlich. $7 \mathrm{Um}-$ gänge. Ungenabelt. Mündung schräg-oval. Außenlippe nicht, Columella stark verdickt; letztere mit kanalartiger Furche. Skulptur aus schrägen, unterhalb der Naht und am Kiel knotig verdickten Rippen; zwischen ihnen feinere Rippen und Furchen. Basis etwa zur Hälfte callusartig glatt, seitlich der Mündung mit 4-5 von feinen Linien gekreuz- 
ten Spiralleisten. Schale grünlichbraun mit purpurbraunen Flecken. Operculum kalkig, seine Außenseite pustulös und mit einer gekurvten Furche. Im Flachwasserbereich. Fundorte: Cabo de La Vela, Media Luna, Ensenada Bonitogordo, Islas del Rosario. Verbreitung: südöstliches Florida, Westindien.

\section{Astraea phoebia RöDING 1798}

(Abb. 24)

Höhe $22,5 \mathrm{~mm}$, Breite $56,5 \mathrm{~mm}$. Gehäuse flach-konisch. Naht nur an den Kielstacheln der Umgänge erkennbar. 5-6 scharf gekielte Umgänge. Nabel schlitzförmig oder ganz vom Columellarcallus bedeckt. Mündung rund-oval, an der Peripherie mit einem dem Kiel entsprechenden Kanal. Auf den Umgängen in Schräg- und Spiralreihen angeordnete lamellöse Erhebungen. Der Kiel in lange, abgeflachte, zur Mündung hin schlitzartig offene Stacheln ausgezogen. Basis mit 5-7 Spiralleisten, gekreuzt von feinen Radiärlamellen. Schale olivgrün bis hellgraubraun; Columellarcallus weiß. Fundort: Islas del Rosario. Verbreitung: Südöstliches Florida, Westindien.

\section{Astraea brevispina Lamarck 1822}

(Abb. 25)

Höhe $32,0 \mathrm{~mm}$, Breite $38,5 \mathrm{~mm}$. Gehäuse kegelig. Naht nur an den Stacheln der Umgänge erkennbar. 5-6 flache, scharf gekielte Umgänge. Ungenabelt. Mündung rund-oval. Umgänge mit zahlreichen Knötchenreihen. Der Kiel in kurze, abgeflachte, zur Mündung hin schlitzartig offene Stacheln ausgezogen. Basis mit 5 knotigen Spiralleisten, deren zweite von außen die stärkste ist. Schale hellolivbraun bis hell-rötlichbraun; die Basis mit einem blutorangen Fleck um die weiße Columella. Fundorte: Cabo de La Vela, $2 \mathrm{~km}$ NE von Manaure, Punta La Loma. Verbreitung: Westindien.

\section{Phasianellidae}

\section{Tricolia affinis affinis C. B. AdAms 1850}

(Abb. 26)

Höhe $8,5 \mathrm{~mm}$, Breite $5,0 \mathrm{~mm}$. Gewinde hoch. Naht deutlich. 5 gewölbte Umgänge. Nabel schlitzförmig. Mündung oval, an der Basis abgestumptt. Außenlippe scharfkantig. Schale glatt bis auf sehr feine Wachstumslinien und mikroskopische Spirallinien. Grundfarbe rosa, mit kleinen dunklen Flecken, häufig in spiraliger Anordnung. Operculum kalkig, oval, weiß. Auf Braunalgen und Seegras im Flachwasserbereich. Fundorte: Bahía Concha, Punta de Betín, Morro de Gaira. Verbreitung: Florida Keys, Westindien.

\section{Neritidae}

\section{Nerita peloronta LINNÉ 1758}

(Abb. 27)

Höhe $42,0 \mathrm{~mm}$, Breite $41,0 \mathrm{~mm}$. Gewinde mäßig erhoben, spitz-konisch. Naht undeutlich. Umgänge gerundet, rasch zunehmend. Mündung weit-ohrförmig. Innenseite 


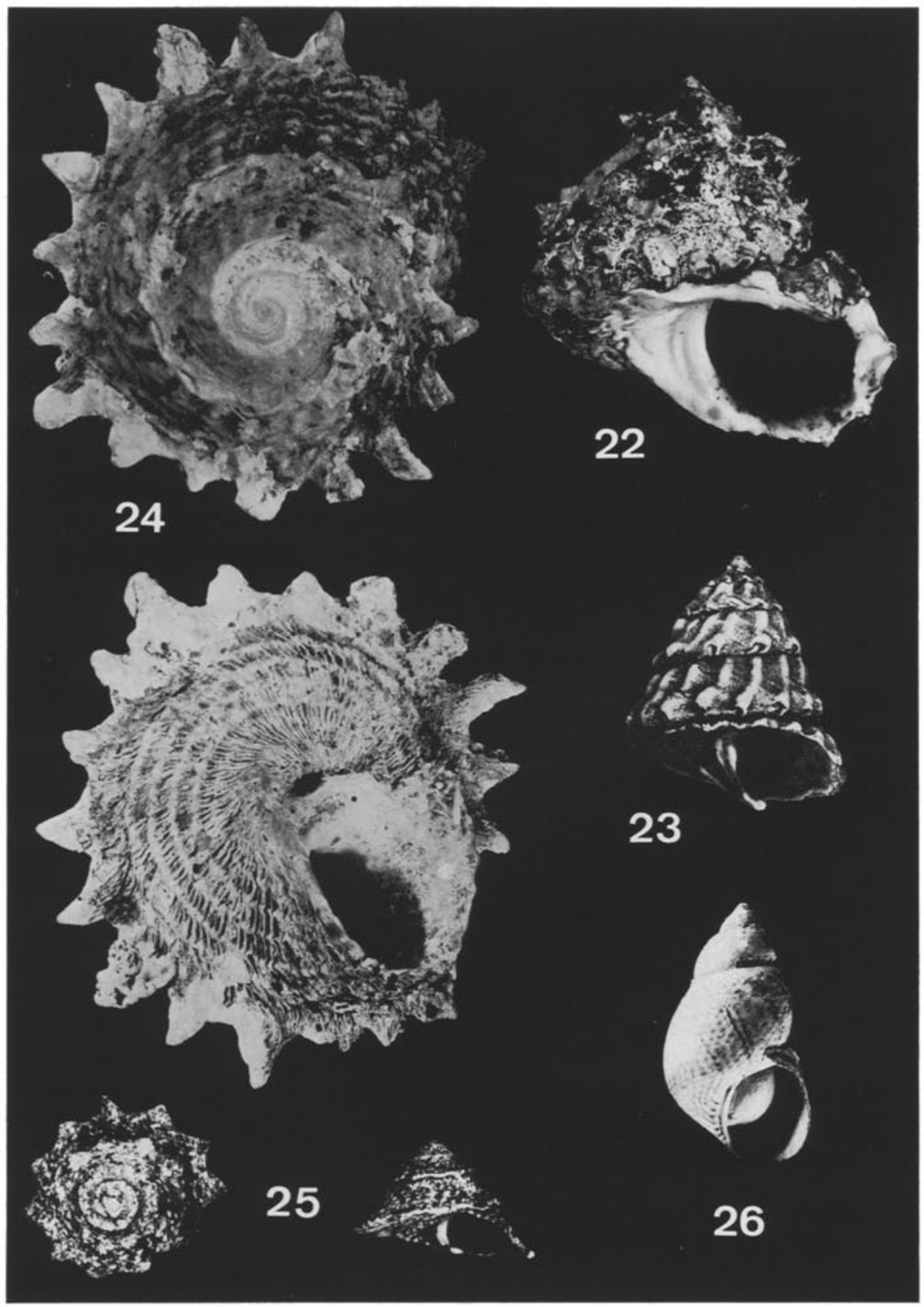

Abb. 22-26: Turbinidae, Phasianellidae. 22: Astraea caelata (45 $\mathrm{mm}$ hoch), 23: Astraea tuber (30 mm), 24: Astraea phoebia (größter Durchmesser $54 \mathrm{~mm}$ ), 25: Astraea brevispina (größter Durchmesser $23 \mathrm{~mm})$, 26: Tricolia affinis affinis $(8,5 \mathrm{~mm}$ hoch) 


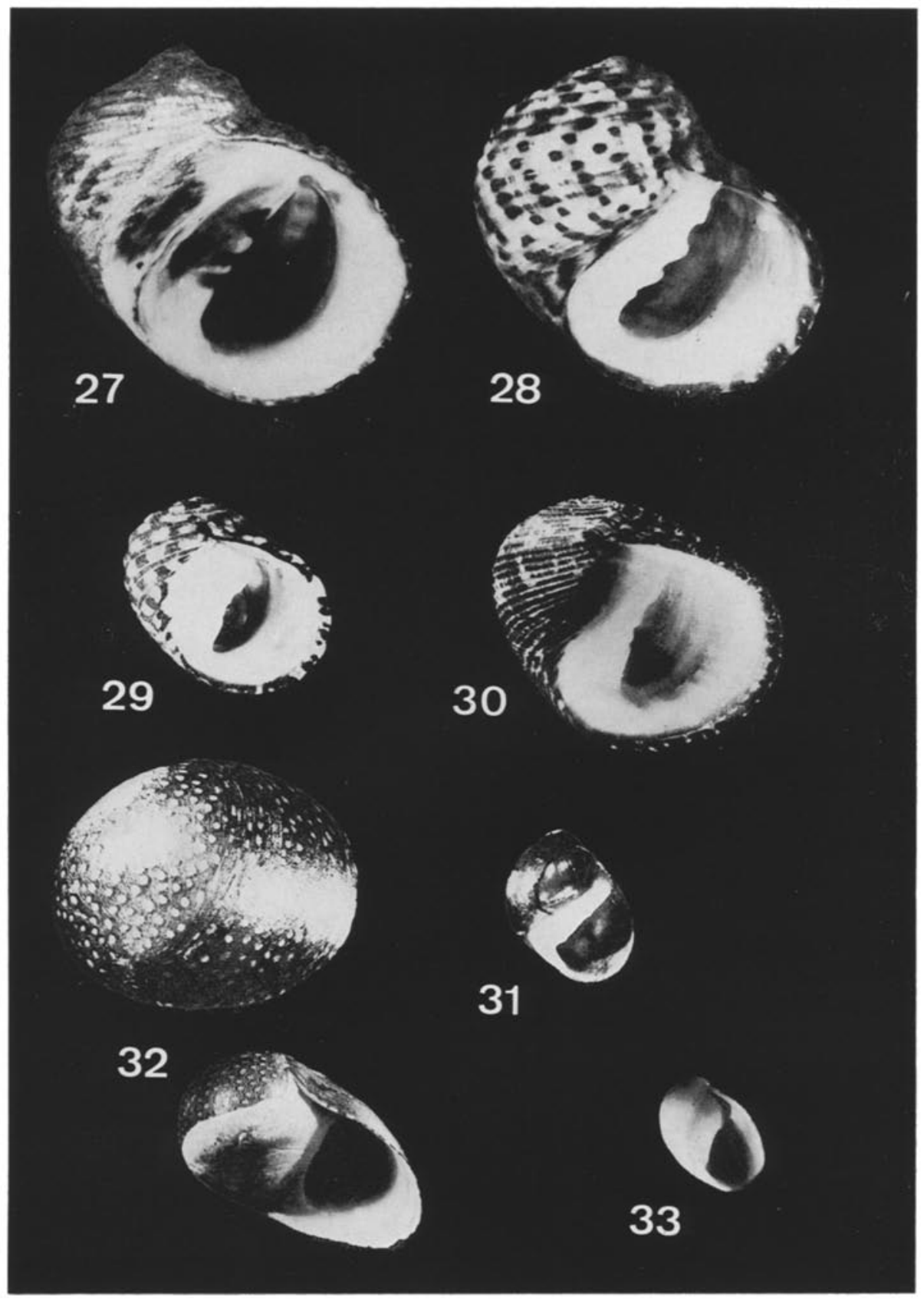

Abb. 27-33: Neritidae. 27: Nerita peloronta (42 $\mathrm{mm}$ hoch), 28: Nerita versicolor $(21 \mathrm{~mm}$ ), 29: Nerita tessellata $(13 \mathrm{~mm}), 30$ : Nerita fulgurans $(15 \mathrm{~mm}), 31:$ Neritina virginea $(9 \mathrm{~mm})$, 32: Neritina punctulata $(17 \mathrm{~mm}), 33$ : Smaragdia viridis viridemaris $(5 \mathrm{~mm})$ 
der Außenlippe gezähnt, der oberste Zahn kräftig und kegelförmig. Parietalschild breit, leicht konkav, mit 2 kräftigen Zähnen. Skulptur aus zahlreichen breiten, abgeflachten Spiralleisten, die von feinen Wachstumslinien gekreuzt werden. Gehäuse olivgrün mit purpurbraunen Flecken oder Zickzackbändern; die Flecken gelegentlich in spiraliger Anordnung. Parietalschild mit großem blutorangem Fleck. Operculum kalkig, seine Innenseite glatt, die Außenseite mit pustulösem, olivgrauem Areal und glattem, dunkelorangem Wulst. In der Brandungszone des Felslitorals; nicht sehr häufig. Fundorte: Ensenada de Granate, Punta de Betín, Bocagrande. Verbreitung: Bermudas, suidöstliches Florida, Westindien.

\section{Nerita versicolor GMELIN 1791}

(Abb. 28)

Höhe $26,5 \mathrm{~mm}$, Breite $25,5 \mathrm{~mm}$. Gewinde mäßig erhoben, stumpf-kegelig. Naht undeutlich. Die 4 gerundeten Umgänge rasch zunehmend. Mündung ohrförmig. Außenlippe breit, bei Adulten auf der Innenseite mit leistenförmigen Zähnchen; der oberste Zahn kräftig und kegelförmig. Parietalschild leicht konvex, mit 4, selten 5 Zähnchen, von denen die beiden mittleren am größten sind. Umgänge und Basis mit zahlreichen flachen Spiralleisten, die von feinen Wachstumslinien gekreuzt werden. Färbung sehr variabel; auf weißgrauem Grund rötliche und schwarze Flecken, teils unregelmäßig geflammt, teils in alternierenden Spiralbändern; manche Gehäuse bis auf wenige weiße Flecken grauschwarz. Operculum kalkig, seine Innenseite glatt, die Außenseite pustulös, hornfarben. In der Brandungszone des Felslitorals, sehr häufig. Fundorte: Bahía Concha, Isla de La Aguja, Ensenada de Granate, zwischen Punta de Granate und Punta Las Minas, Punta de Betín, Ancon, Morro de Gaira. Verbreitung: Bermudas, Südflorida. Westindien.

\section{Nerita tessellata GMELIN 1791}

(Abb. 29)

Höhe 14,0 mm, Breite 14,0 mm. Gewinde wenig erhoben. Apex häufig korrodiert. Naht sehr undeutlich. Umgänge rasch zunehmend; der letzte breit-gerundet. Mündung ohrförmig, an der Innenseite mit zähnchenartigen Falten, von denen die beiden oberen kräftiger sind als die übrigen. Parietalschild leicht konkav, pustulös, am Innenrand mit 2 feinen Zähnchen. Umgänge mit zahlreichen breiten, abgeflachten Spiralleisten. Schale entweder auf weißem Grund schwarz gefleckt oder schwarz mit wenigen weißen Flekken. Mündung und Parietalschild blauweiß. Operculum kalkig, Außenseite pustulös, Innenseite glatt. Sehr häufig im Felslitoral der Brandungszone. Fundorte: Bahía Concha, Ensenada de Granate, zwischen Punta de Granate und Punta Las Minas, Punta de Betín, Bocagrande. Verbreitung: Bermudas, von Florida bis Texas, Westindien bis Brasilien.

\section{Nerita fulgurans GMELIN 1791}

(Abb. 30)

Höhe $15,0 \mathrm{~mm}$, Breite $16,0 \mathrm{~mm}$. Gewinde kaum über den letzten Umgang erhoben. Naht undeutlich. Letzter Umgang sehr rasch zunehmend. Mündung breitohrförmig. Außenlippe gezähnt, auf der Innenseite mit einer Reihe faltenartiger Zähn- 
chen, die beiden oberen stärker als die übrigen. Parietalschild gerade bis leicht konkav, an der Innenkante mit 2 feinen Zähnchen. Auf den Umgängen zahlreiche schmale, abgeflachte Spiralleisten und feine Wachstumslinien. Schale schwarz mit grauweißen Flecken. Mündung und Parietalschild blauweiß. Operculum kalkig, Außenseite pustulös, Innenseite glatt, hellgrau. Die Art dringt in Brackwasser vor. Fundort: Tolú. Verbreitung: Bermudas, Südostflorida, Westindien.

\section{Neritina virginea LINNÉ 1758}

(Abb. 31)

Höhe 13,0 mm, Breite 13,0 mm. Gewinde mäßig erhoben. Apex häufig korrodiert. Letzter Umgang rasch zunehmend. Mündung ohrförmig. Außenlippe scharf. Parietalschild dick, mit feinen Zähnchen an der Innenkante. Schale bis auf feine Wachstumslinien glatt. Färbung sehr variabel; Grundton oliv mit hellen ovalen Flecken oder dunklen geschweiften Bändern, manchmal mit hellem Spiralband an der Peripherie des letzten Umgangs; einige Schalen fast schwarz. Parietalschild elfenbeinfarben. Operculum kalkig, beide Seiten glatt, hell- bis dunkelgrau. Sehr häufig auf Muddböden in brackigem Flachwasser. Fundorte: $8 \mathrm{~km}$ NE von Manaure, Buritaca, Puebloviejo. Verbreitung: Bermudas, von Florida bis Texas, Westindien.

\section{Neritina punctulata LAMARcK 1816}

(Abb. 32)

Höhe $20,5 \mathrm{~mm}$, Breite 24,0 mm. Gewinde nur wenig erhoben. Apex meist stark korrodiert. Letzter Umgang sehr breit, Mündung ohrförmig. Außenlippe scharf. Parietalschild dick, glatt, in Mittelfeld seines Innenrandes sehr fein gezähnt. Schale bis auf feine Wachstumslinien glatt. Olivgrün mit zahlreichen gelbbraunen ovalen Flecken. Mündung blauweiß, Parietalschild gelborange. Operculum kalkig, fleischfarben. Im Süßwasser lebend, jedoch gelegentlich im Küstenspülsaum. Fundort: Buritaca. Verbreitung: Mittelamerika, Antillen.

\section{Smaragdia viridis viridemaris MAURY 1917}

(Abb. 33)

Höhe $6,0 \mathrm{~mm}$, Breite $4,0 \mathrm{~mm}$. Gehäuse im Umriß schräg-oval. Gewinde mäßig erhoben. Letzter Umgang nach unten stark erweitert. Mündung elliptisch bis ohrförmig. Außenlippe scharfkantig. Parietalschild dick, an der Innenkante fein gezähnt. Schale glatt; hell- bis lindgrün. Auf Seegraswiesen im Flachwasserbereich. Fundorte: Bahía Concha, Ensenada Bonitogordo. Verbreitung: Bermudas, Südostflorida, Westindien.

\section{Littorinidae}

\section{Littorina ziczac GMELIN 1791}

(Abb. 34)

Höhe $18,0 \mathrm{~mm}$, Breite $10,0 \mathrm{~mm}$. Gehäuse spitz-konisch. Gewinde hoch. Naht deutlich. 8 schwach gerundete Umgänge, der letzte stumpf-gekielt. Nabel bedeckt; zwischen Basis und Columella häufig eine schmale Rinne. Mündung oval, nach oben 
zugespitzt. Umgänge mit sehr feinen Spiral- und Wachstumslinien. Schale blauweiß, unter der Naht heller, mit zahlreichen braunen, schrägen oder Zickzackbändern. Mündung schokoladenbraun mit 2 breiten, helleren Bändern. Columella braun. Operculum nicht verkalkt, ohrförmig, dunkelbraun. Sehr häufig auf Felsen und Steinen der Brandungszone. Fundorte: Riohacha, Bahía Concha, Ensenada de Granate, zwischen Punta de Granate und Punta Las Minas, Punta de Betín, Morro de Gaira, Bocagrande. Verbreitung: Bermudas, südliches Florida, Westindien.

\section{Littorina lineolata ORBIGNY 1840}

(Abb. 35)

Höhe 19,5 mm, Breite 11,5 mm. Gehäuse spitz-konisch, Gewinde hoch, Apex spitz. Naht deutlich. 7 mäßig gerundete Umgänge, der letzte stumpf-gekielt. Mündung breitoval. Außenlippe scharf. Parietalschild konkav mit verdickter Leiste am Innenrand und schwacher, zur Schalenbasis ziehender Furche. Umgänge mit feinen Spiral- und Wachstumslinien. Schale blauweiß, mit einem grauen bis schwarzen Spiralband auf der unteren Hälfte der Umgänge (auf letztem Umgang oberhalb des Kieles) und wellenoder zickzackförmigen, grauschwarzen Linien. Columella und Mündung dunkelbraun, letztere mit 2 hellen Bändern. Operculum nicht verkalkt, hornfarben. Häufig in der Brandungszone von Felsküsten. Fundorte: Riohacha, Bahía Concha, zwischen Punta de Granate und Punta Las Minas, Mündung Ciénaga Grande de Santa Marta, Bocagrande, Tolú. Verbreitung: Südflorida bis Texas, Karibische See.

\section{Littorina nebulosa LAMARcK 1822}

(Abb. 36)

Höhe $19,0 \mathrm{~mm}$, Breite $13,0 \mathrm{~mm}$. Gewinde konisch. Apex spitz. Naht deutlich. 6-9 mäßig gewölbte Umgänge. Mündung breit-oval, oben leicht zugespitzt. Columella verdickt, mit breiter Längsfurche und scharfem Rand. Die ersten Umgänge glatt, die übrigen mit zahlreichen feinen Spiral- und schrägen Wachstumslinien. Schale elfenbeinfarben bis hellbraun, mit unregelmäßigen dunkelbraunen Flecken, Spiral- oder Zickzackbändern. Verdickte Innenkante der Columella weiß, um die Längsfurche purpurbraun. Auf steinigem Substrat in der Gezeitenzone. Fundorte: Don Diego (auf angespülten Baumstämmen), Mündung Ciénaga Grande de Santa Marta, Bocagrande, Tolú. Verbreitung: Westindien.

\section{Littorina meleagris Potiez \& Michaud 1838}

(Abb. 37)

Höhe 5,0 mm, Breite $3,0 \mathrm{~mm}$. Gehäuse oval-turmförmig. Naht deutlich. 5-6 schwach gewölbte Umgänge. Nabel schlitzförmig. Mündung birnenförmig. Auf den Umgängen feine Wachstumslinien. Schale hell- bis dunkelbraun, mit spiralig angeordneten weißen Flecken; unter der Naht schräge, alternierend weiße und braune Streifen. Columella braun. Fundorte: Bahía Concha, Ensenada Bonitogordo, zwischen Punta de Granate und Punta Las Minas, Punta de Betín. Verbreitung: Südliches Florida, Bahamas, Westindien, Nordküste Südamerikas. 


\section{Nodilittorina tuberculata MENKE 1828}

(Abb. 38)

Höhe 13,0 mm, Breite 9,0 mm. Gehäuse spitz-kegelig. Apex spitz. Naht nicht sehr deutlich. Ungenabelt. Mündung rund-oval; Außenlippe scharf; Columella nach unten verbreitert, mit Längsfurche. Skulptur aus mehreren Spiralreihen spitzer Knötchen, die der beiden Reihen auf der Schulter am größten und paarweise untereinander stehend. Zwischen den Knotenreihen feine Spiral- und Wachstumslinien. Schale olivgrau bis graubraun, die Knötchen heller und nahe der Außenlippe hellorange. Columella und Mündung dunkelbraun. Auf Felsen in der Brandungszone. Fundorte: Zwischen Punta de Granate und Punta Las Minas, Punta de Betín. Verbreitung: Bermudas, Südflorida, Westindien.

\section{Tectarius muricatus LiNNÉ 1758}

(Abb. 39)

Höhe $21,0 \mathrm{~mm}$, Breite $16,0 \mathrm{~mm}$. Gewinde konisch. Apex spitz. Naht deutlich. Die 8-10 Umgänge leicht stufig abgesetzt, kaum gewölbt. Letzter Umgang gleichmäßig gerundet. Nabel eng, weitgehend durch umgeschlagene Columella bedeckt, so daß eine Rinne zur Basis gebildet wird. Mündung rundlich-oval, schräggestellt, nach oben etwas zugespitzt. Auf den Umgängen 5 spiralige Knotenreihen, Basis mit Spiralreihen abgeflachter Knötchen. Gehäuse graugrün bis graubraun, die Knötchen deutlich heller. Operculum nicht verkalkt, braun. Im Bereich der Hochwasserlinie auf Hartböden. Häufig. Fundorte: Ensenada Bonitogordo, Ensenada de Granate, Punta de Betín, Bocagrande. Verbreitung: Bermudas, Südflorida, Westindien, Mittelamerika.

\section{Rissoidae}

\section{Rissoina bryerea Montagu 1803}

(Abb. 40)

Höhe $5 \mathrm{~mm}$, Breite 1,7 mm. Schale turmförmig, weiß, Apex spitz. 6-7 leicht konvexe Umgänge, Naht deutlich. Umgänge gerippt: auf dem letzten Umgang 16-22 schmale, hohe Rippen. Ungenabelt. Mündung länglich-oval, schräggestellt, unten leicht ausgebuchtet. Fladhwasserform. Fundort: Ensenada Bonitogordo. Verbreitung: südliches Florida bis Kleine Antillen.

\section{Turritellidae}

\section{Turritella variegata LINNÉ 1758}

(Abb. 41)

Höhe $95 \mathrm{~mm}$, Breite $25 \mathrm{~mm}$. Gehäuse schlank turmförmig. 12 flache Umgänge, oben leicht, unten deutlich geschultert. Naht tief eingezogen. Ungenabelt. Mündung gerundet quadratisch. Zahlreiche feine und gröbere Spiralstreifen auf den Windungen. Farbe variabel, oft blaßbraun mit dunkleren Flecken und Streifen oder rötlich bis bräunlich geflammt. Fundorte: $8 \mathrm{~km}$ NE von Manaure, Bahía Concha, Ensenada Bonitogordo. Verbreitung: Westindien. 


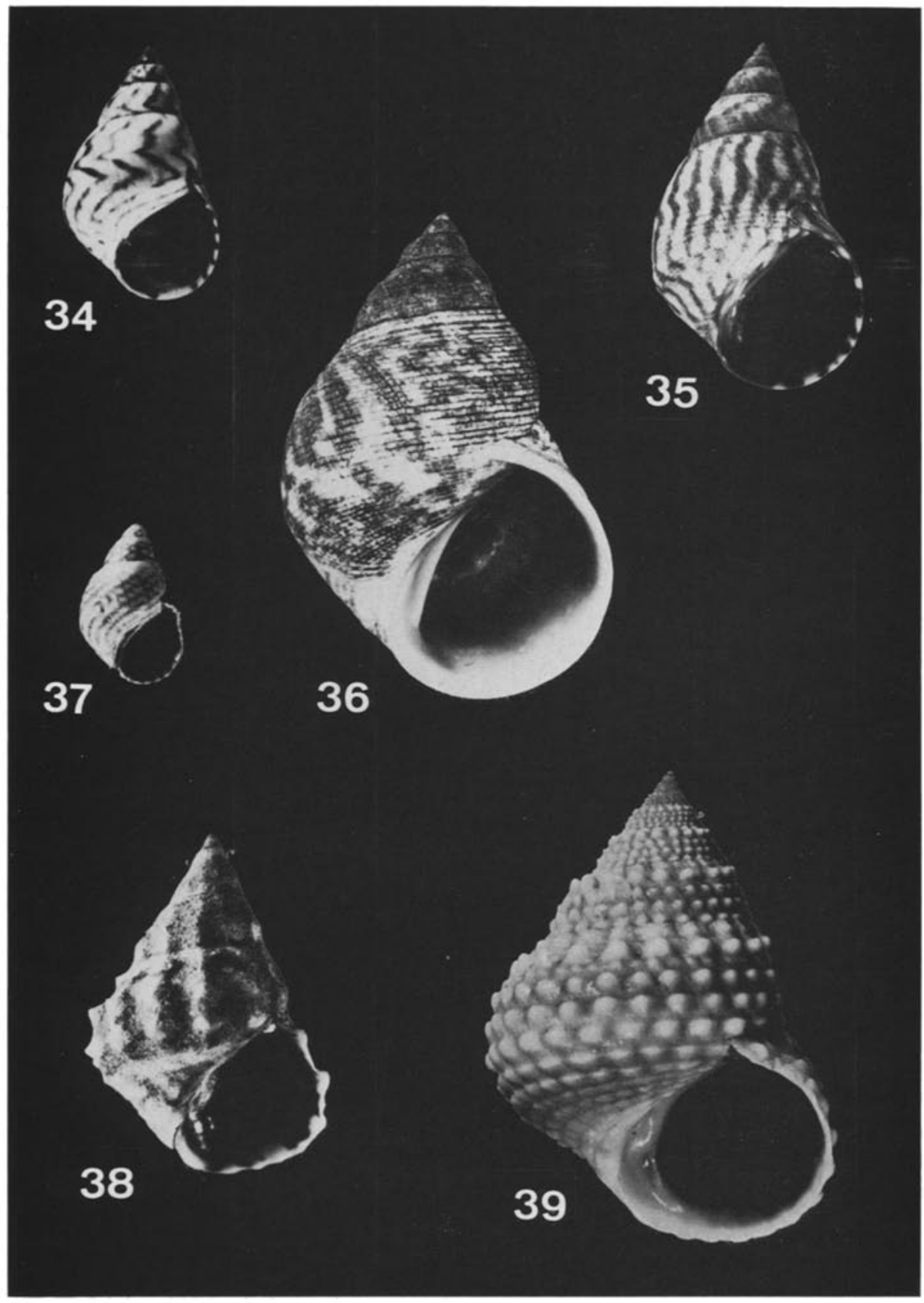

Abb. 34-39: Littorinidae. 34: Littorina ziczac (11 mm hoch), 35: Littorina lineolata (15 mm), 36: Littorina nebulosa $(19 \mathrm{~mm}), 37$ : Litorina meleagris $(5 \mathrm{~mm}), 38:$ Nodilitorina tuberculata (11 $\mathrm{mm}), 39:$ Tectarius muricatus $(20 \mathrm{~mm})$ 


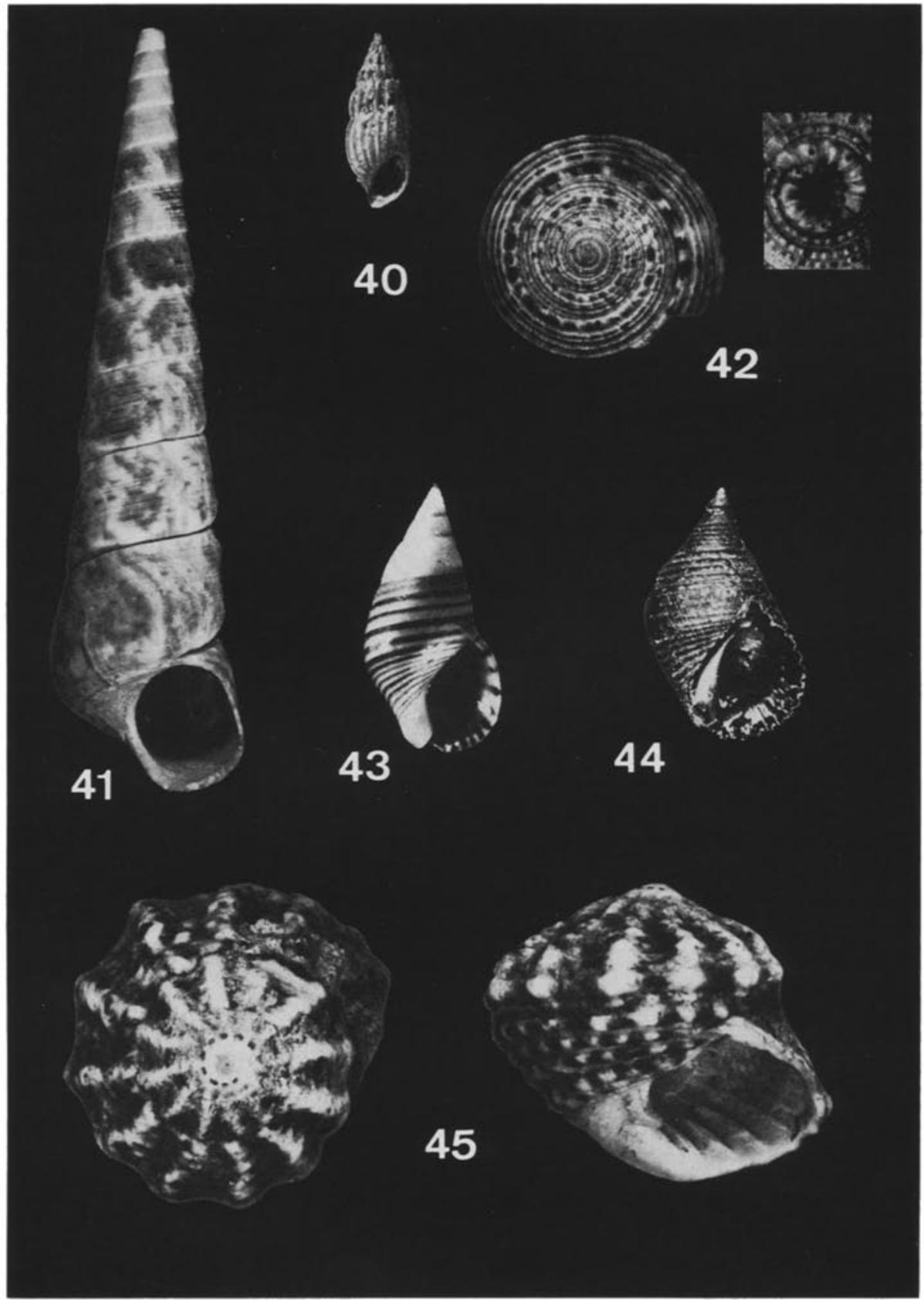

Abb. 40-45: Rissoidae, Turritellidae, Architectonicidae, Planaxidae, Modulidae. 40: Rissoina bryerea $(4,5 \mathrm{~mm}$ hoch), 41: Turritella variegata $(95 \mathrm{~mm}), 42:$ Architectonica nobilis (Durchmesser $32 \mathrm{~mm}$ ) (im Ausschnitt: Umbilicalfeld), 43: Planaxis lineatus ( $8 \mathrm{~mm}$ hoch), 44 : Planaxis nucleus $(17 \mathrm{~mm}), 45:$ Modulus modulus (13 $\mathrm{mm}$ hoch) 


\section{Architectonicidae}

\section{Architectonica nobilis RöDING 1798}

(Abb. 42)

Höhe $15 \mathrm{~mm}$, Breite $32 \mathrm{~mm}$. Gehäuse flach kegelförmig. 7-8 leicht konvexe Umgänge. Naht deutlich eingezogen. Letzter Umgang durch randständigen Spiralreifen kantig. Umgänge mit 4-5 quergeturchten Spiralreifen. Nabel perspektivisch weit, zahnradartig gekerbt. Gehäuse orangebräunlich mit roten Flecken. Unterhalb der Niedrigwasserlinie auf Sandböden. Fundort: Bahía Concha. Verbreitung: Florida, Texas, Westindien.

\section{Planaxidae}

\section{Planaxis lineatus DA CosTA 1778}

(Abb. 43)

Höhe $8 \mathrm{~mm}$, Breite $4 \mathrm{~mm}$. Gehäuse turmförmig, Umriß leicht konvex, Apex spitz. Naht deutlich. 6-7 Umgänge. Ungenabelt. Mündung oval, mit schmaler Bucht am unteren Ende. Schale gelblichbraun mit dunkelbraunen Spiralstreifen. Zahlreich an Felsen der Gezeitenzone. Fundorte: Ensenada de Granate, zwischen Punta de Granate und Punta Las Minas. Verbreitung: Lower Florida Keys, Westindien.

\section{Planaxis nucleus BRUGUIÈre 1789}

(Abb. 44)

Höhe $18 \mathrm{~mm}$, Breite $11 \mathrm{~mm}$. Gehäuse dickwandig. Apex spitz, oft korrodiert. Naht deutlich. Letzter Umgang nimmt etwa $2 / 3$ der Gesamthöhe ein. Ungenabelt. Mündung birnenförmig, oben und unten schmal gebuchtet. 6 Umgänge mit breiten, abgeflachten Spiralreifen, die durch schmale Furchen getrennt und in der Mündung sichtbar sind, und feinen Querstreifen. Gehäuse dunkelolivbraun bis schwarz. Columella rosa bis hellpurpurn. Häufig im Felslitoral. Jungtiere werden in einer Bruttasche getragen. Fundorte: Bahía Concha, Ensenada Bonitogordo, Isla de La Aguja, Ensenada de Granate, Punta de Betín, Morro de Gaira. Verbreitung: Südöstliches Florida und Westindien.

\section{Modulidae \\ Modulus modulus LINNÉ 1758}

(Abb. 45)

Höhe $15 \mathrm{~mm}$, Breite $17 \mathrm{~mm}$. Gehäuse kreiselförmig, festschalig. 5-6 kantige Umgänge, mit kräftigen Spiralreifen und Querrippen. Endwindung dominierend. Eng genabelt. Mündung rundlich. Mündungsrand am Spindelende mit kräfligem, querstehendem Zahn. Gehäuse bräunlichweiß mit dunkelbraunen Flecken, oft von Algen bewachsen. In Seegraswiesen des flachen. Wassers. Fundorte: Ensenada Bonitogordo, Ensenada de Granate, Punta de Betín, Mündung der Ciénaga Grande de Santa Marta. Verbreitung: Florida, Texas, Westindien. 
Potamididae

\section{Batillaria minima GMeLIN 1791}

(Abb. 46)

Höhe $13 \mathrm{~mm}$, Breite $6 \mathrm{~mm}$. Gehäuse turmförmig, Umriß leicht konvex. 6-7 Umgänge mit knotentragenden Spiralreifen. Ungenabelt. Mündung rundlich-oval mit einer oberen und einer weiten unteren Bucht. Am Operculum leicht von äußerlich ähnlichen Cerithium-Arten zu unterscheiden: Es ist fast kreisrund mit zentral gelegenem Kern (multispiral), bei Cerithinm dagegen oval mit exzentrischem Kern (paucispiral). Gehäuse kakao- bis dunkelbraun. Im Bereich der Hochwasserlinie stellenweise sehr häufig. Fundort: Bocachica. Verbreitung: Südliches Florida und Westindien.

\section{Cerithidae}

Alaba incerta ORBIGNY 1842

(Abb. 47)

Höhe $10 \mathrm{~mm}$, Breite 3,4 mm. Gehäuse schlank turmförmig, dünnschalig. Etwa 9 stark gewölbte Umgänge mit zur Mündung hin deutlicher werdenden Spiralstreifen und Varizen. Ungenabelt. Mündung oval. Apex dunkelbraun, jüngere Umgänge fast weiß, manchmal mit hellbraunen Flecken. Fundort: Ensenada de Granate. Verbreitung: Bermudas, Bahamas, südöstliches Florida, Antillen, Mittelamerika.

\section{Ceritbium variabile C. B. AdAMs 1845}

(Abb. 48)

Höhe $11 \mathrm{~mm}$, Breite $5 \mathrm{~mm}$. Gehäuse turmförmig. 6-7 Umgänge mit knotentragenden Spiralstreifen. Unregelmäßig verteilte Varizen. Mündungsseite des Gehäuses oft etwas abgeflacht. Ungenabelt. Mündung rundlich oval mit oberer und unterer Bucht. Am ovalen Operculum leicht von Batillaria zu unterscheiden. Gehäuse mittelbraun bis fast schwarz. Häufig unter Steinen. Fundort: Ensenada Bonitogordo. Verbreitung: südliches Florida bis Texas, Westindien.

\section{Cerithium litteratum BORN 1778}

(Abb. 49)

Höhe $22 \mathrm{~mm}$, Breite $9 \mathrm{~mm}$. Gedrungen turmförmig. Mündungsseite des Gehäuses etwas abgeflacht. Mit zahlreichen Spiralstreifen, von denen 1-2 deutlicher hervortreten und pro Umgang etwa 12 spitze Knötchen tragen. Ungenabelt. Mündung oval mit fast gleichgroßen oberen und unteren Buchten, schräggestellt. Gehäuse hellgraugrün mit feinen schwarzen Punkten. Oft mit Algen bewachsen. Im Sublitoral häufig. Fundorte: Bahía Concha, Ensenada Bonitogordo, Ensenada de Granate, zwischen Punta de Granate und Punta Las Minas, Punta de Betín, Bocachica. Verbreitung: Südöstliches Florida, Bermudas, Westindien. 


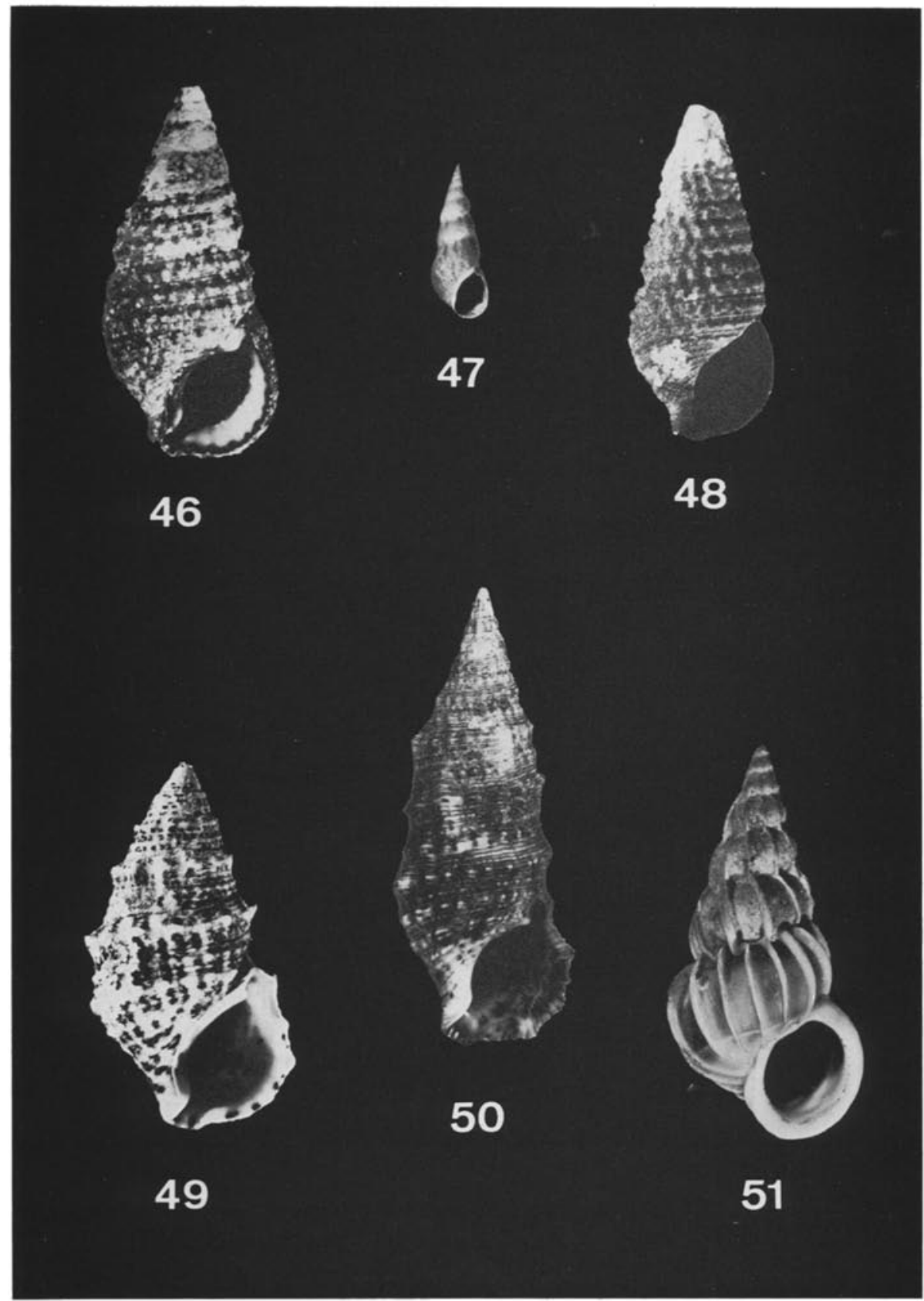

Abb. 46-51: Potamididae, Cerithiidae, Epitoniidae. 46: Batillaria minima (12 $\mathrm{mm}$ hoch), 47: Alaba incerta $(5,5 \mathrm{~mm}), 48$ : Cerithium variabile $(11 \mathrm{~mm})$, 49: Cerithinm litteratum $(15 \mathrm{~mm}), 50$ : Ceritbium ebumeum $(29,5 \mathrm{~mm}), 51$ : Epitonium lamellosum $(18 \mathrm{~mm})$ 


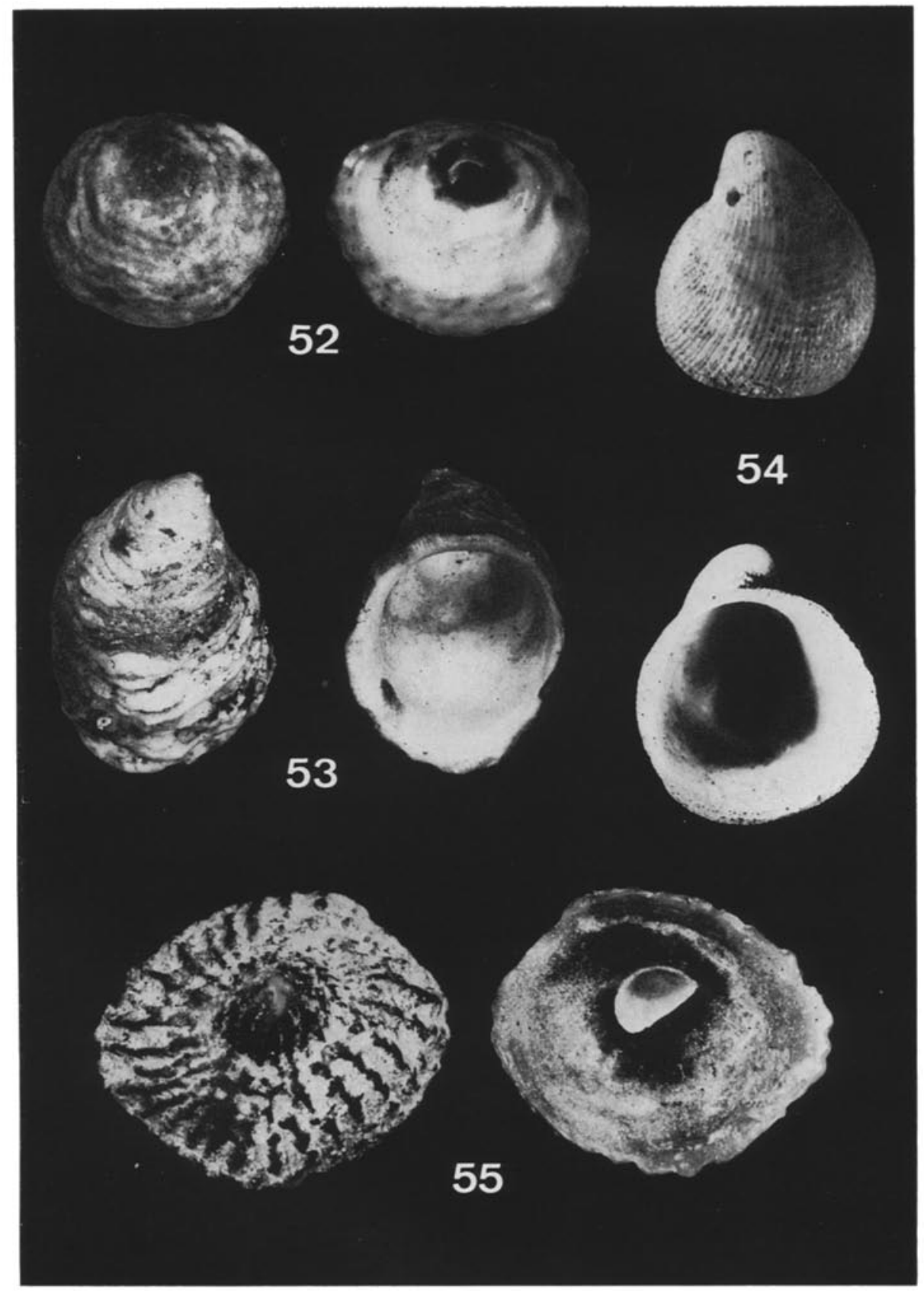

Abb. 52-55: Hipponicidae, Capulidae, Calyptraeidae. 52: Cheilea equestris (größter Durchmesser $17 \mathrm{~mm}), 53$ : Hipponix antiquatus $(20 \mathrm{~mm}), 54:$ Capulus intortus $(10 \mathrm{~mm}), 55:$ Crucibulum auricula $(23 \mathrm{~mm})$ 


\section{Cerithium eburneum BRUGUìre 1792}

(Abb. 50)

Höhe $30 \mathrm{~mm}$, Breite $12 \mathrm{~mm}$. Turmförmig, Seiten konvex. 11 Umgänge mit zahlreichen Spiralstreifen und unregelmäßig angeordneten Varizen. 3-4 Spiralreihen spitzer Knötchen (16-18 pro Umgang). Ungenabelt. Mündung oval, schräggestellt, nach außen leicht erweitert. Hellbraun mit dunkelbraunen Flecken. Mündung innen weiß mit dunkelbraunen Stricheln und Flecken. Im felsigen Sublitoral häufig. Fundorte: Bahía Concha, zwischen Punta de Granate und Punta Las Minas, Bocachica. Verbreitung: Südöstliches Florida, Bahamas, Große Antillen, Westindien.

\section{Epitonidae}

\section{Epitonium lamellosum LAMARCK 1822}

(Abb. 51)

Höhe 15,1 mm, Breite 7,3 mm. Gewinde hod, steil-konisch. Apex spitz. Naht eingetieft. 11 bauchige Umgänge. Ungenabelt. Mündung rund, Außenlippe verdickt. Skulptur aus zahlreichen axialen, hohen und blattförmigen Rippen, die untereinanderstehen. An der Basis eine Spiralleiste. Schale weißlich, mit unregelmäßigen braunen Flecken. Gelegentlich die gesamte Oberfläche der Umgänge hellbraun. Unterhalb der Naht eine dunkelbraune Spirallinie. Fundorte: Ensenada Bonitogordo, Punta La Loma. Verbreitung: Ostatlantik von Finisterre bis Liberia und Goldküste, westliches Mittelmeer; Westatlantik von Südflorida, Bermudas über Golf von Mexiko und Westindien bis Tobago.

\section{Hipponicidae}

\section{Cbeilea equestris LINNÉ 1758}

(Abb. 52)

Höhe $6 \mathrm{~mm}$, Breite $17 \mathrm{~mm}$. Napfförmig. Embryonalgewinde spiralig, aber meist abgestoßen. Mündung in Anpassung an die Unterlage kreisrund bis oval. Vom Apex aus geht nach innen ein halbtrichterförmiger kalkiger Fortsatz. Oberfläche mit mehr oder weniger konzentrischen Wülsten und feiner radiärer Streifung. Kein Operculum. Gehäuse weiß bis gelblichbraun. Tiere festsitzend auf Steinen, Schalen und anderem harten Material. Fundorte: Bahía Concha, Ensenada de Granate. Verbreitung: Westindien.

\section{Hipponix antiquatus LINNÉ 1767}

(Abb. 53)

Höhe $12 \mathrm{~mm}$, Breite $14 \mathrm{~mm}$, Länge $21 \mathrm{~mm}$. Gehäuse napf- bis mützenförmig. Spiralige Embryonalschale meist korrodiert. Apex überragt den Hinterrand of beträchtlich. Oberfläche mit unregelmäßigen konzentrischen Wülsten. Auf der Innenseite ein deutlicher, hufeisenförmiger Muskeleindruck. Kein Operculum. Gehäuse kalkigweiß. Festsitzend auf Steinen, Schalen und anderem Hartmaterial. Fundorte: Bahía Concha, Ensenada de Granate, Punta de Betín, Punta La Loma. Verbreitung: Südöstliches Florida, Westindien, Kalifornien bis Peru. 
Capulidae

Capulus intortus LAMARCK 1822

(Abb. 54)

Höhe $5 \mathrm{~mm}$, Breite $8,5 \mathrm{~mm}$, Länge $10 \mathrm{~mm}$. Gehäuse mützenförmig mit eingerolltem, nach hinten gerichtetem Apex. Mündung weit, fast kreisrund. Ohne Operculum. Oberfläche bei guter Erhaltung durch konzentrische und spiralige Streifung gegittert. Gehäuse gelblichbraun oder kalkigweiß, je nach Erhaltung. Fundorte; Bahía Concha, Ensenada de Granate. Verbreitung: Florida, Westindien.

\section{Calyptraeidae}

\section{Crucibulum auricula GMELIN 1791}

(Abb. 55)

Höhe $10 \mathrm{~mm}$, Breite $27 \mathrm{~mm}$, Länge $31 \mathrm{~mm}$. Gehäuse napfförmig. Apex fast zentral gelegen. Oberfläche mit kräftigen radialen, gewellten Rippen. Apex glatt. Im Inneren große, tïtenförmige Kalklamelle, deren Rand frei ist. Gehäuse gelblich bis rötlich. Fundorte: Cabo de La Vela, $8 \mathrm{~km}$ NE von Manaure, Bahía Concha, Ensenada de Granate. Verbreitung: Florida, Westindien.

\section{Crepidula aculeata GMELIN 1791}

(Abb. 56)

Höhe $6 \mathrm{~mm}$, Breite $14 \mathrm{~mm}$, Länge $18 \mathrm{~mm}$. Gehäuse flach napfförmig, im Umriß oval. Spiraliger Apex randständig. Unterseite mit einem queren Septum, das seitlich apicad eingebuchtet ist („Pantoffelschnecke“). Oberfläche mit spiraligen Rippen, darauf scharfe Höcker, die sich am Rande zu kleinen Stacheln erheben. Außen hellbraun, oft bewachsen. Auf Steinen und Schalen (lebend auf Pinctada radiata gesammelt). Fundort: Cabo de La Vela. Verbreitung: Südöstliche USA, Westindien.

\section{Crepidula convexa SAY 1822}

(Abb. 57)

Höhe $5 \mathrm{~mm}$, Breite $12 \mathrm{~mm}$, Länge $17 \mathrm{~mm}$. Gehäuse mützenförmig mit weit vorgezogenem Apex. Septum auf der Unterseite mit unregelmäßigem, meist konkavem Rand. Oberfläche glatt oder konzentrisch und radial gestreift. Oberfläche oliv-bis purpurbraun, rotbraun gefleckt. Fundorte: Pájaro, Ancon. Verbreitung: Südöstliche USA, Westindien.

$$
\text { Crepidula plana SAY } 1822
$$

Höhe $5 \mathrm{~mm}$, Breite $18 \mathrm{~mm}$, Länge $29 \mathrm{~mm}$. Gehäuse flachgedrückt, im apicalen Bereich konvex, darunter konkav gebogen. Apex randständig. Oberfläche konzentrisch gestreift. Septum auf einer Seite und in der Mitte apicad eingebuchtet. Periostracum hellbraun, meist korrodiert: Schale dann kalkweiß. In und auf leeren Schalen. Am Fundort Puebloviejo in leeren Gehäusen von Melongena. Fundorte: Sta. Marta (Rodadero de Gaira), Puebloviejo. Verbreitung: Ostliche USA, Westindien. 


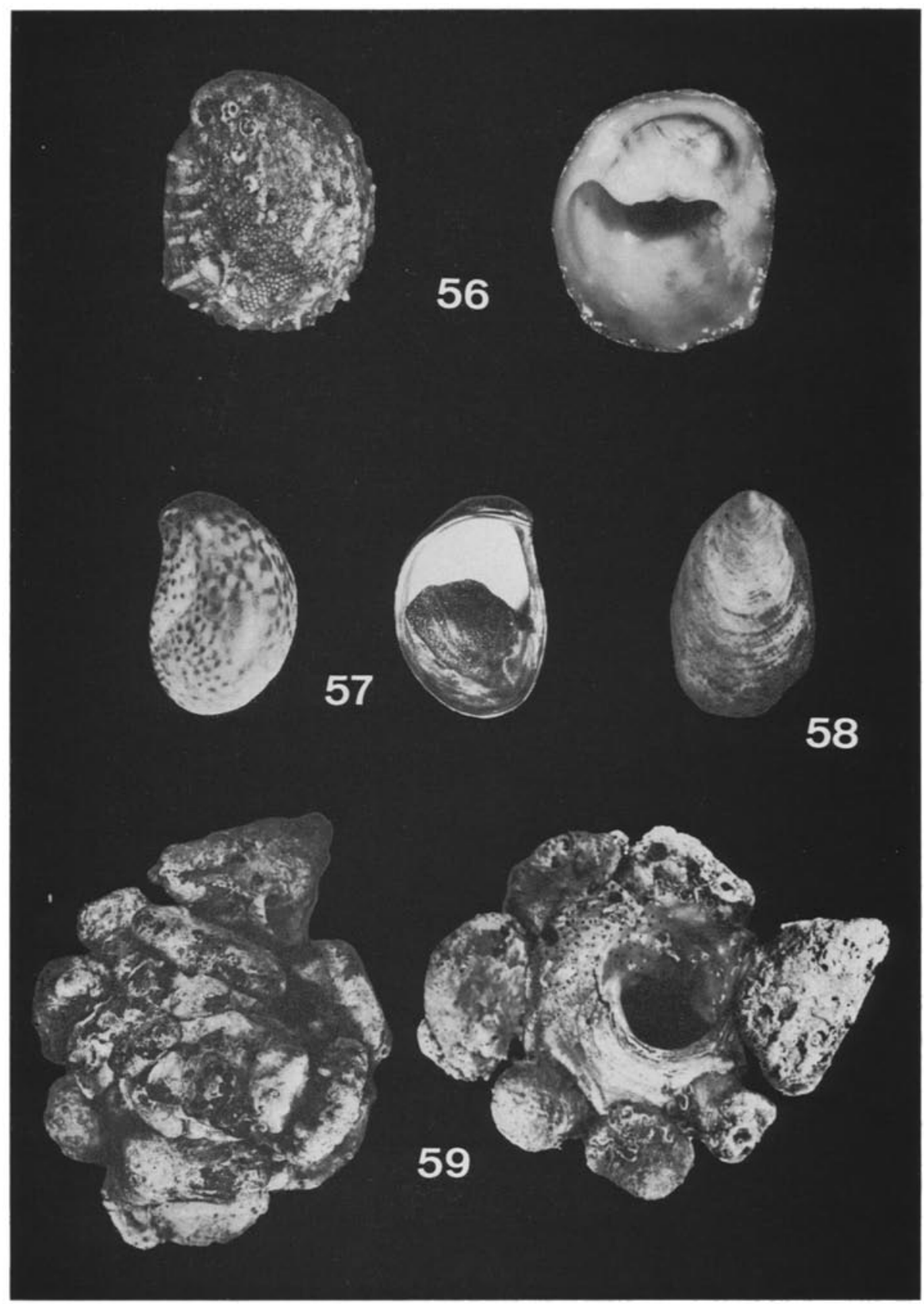

Abb. 56-59: Calyptraeidae, Xenophoridae. 56: Crepidula aculeata (17 mm), 57: Crepidula convexa $(14,5 \mathrm{~mm}), 58$ : Crepidula plana $(28,5 \mathrm{~mm}), 59$ : Xenophora concbyliopbora (größter Durchmesser $117 \mathrm{~mm}$ ) 


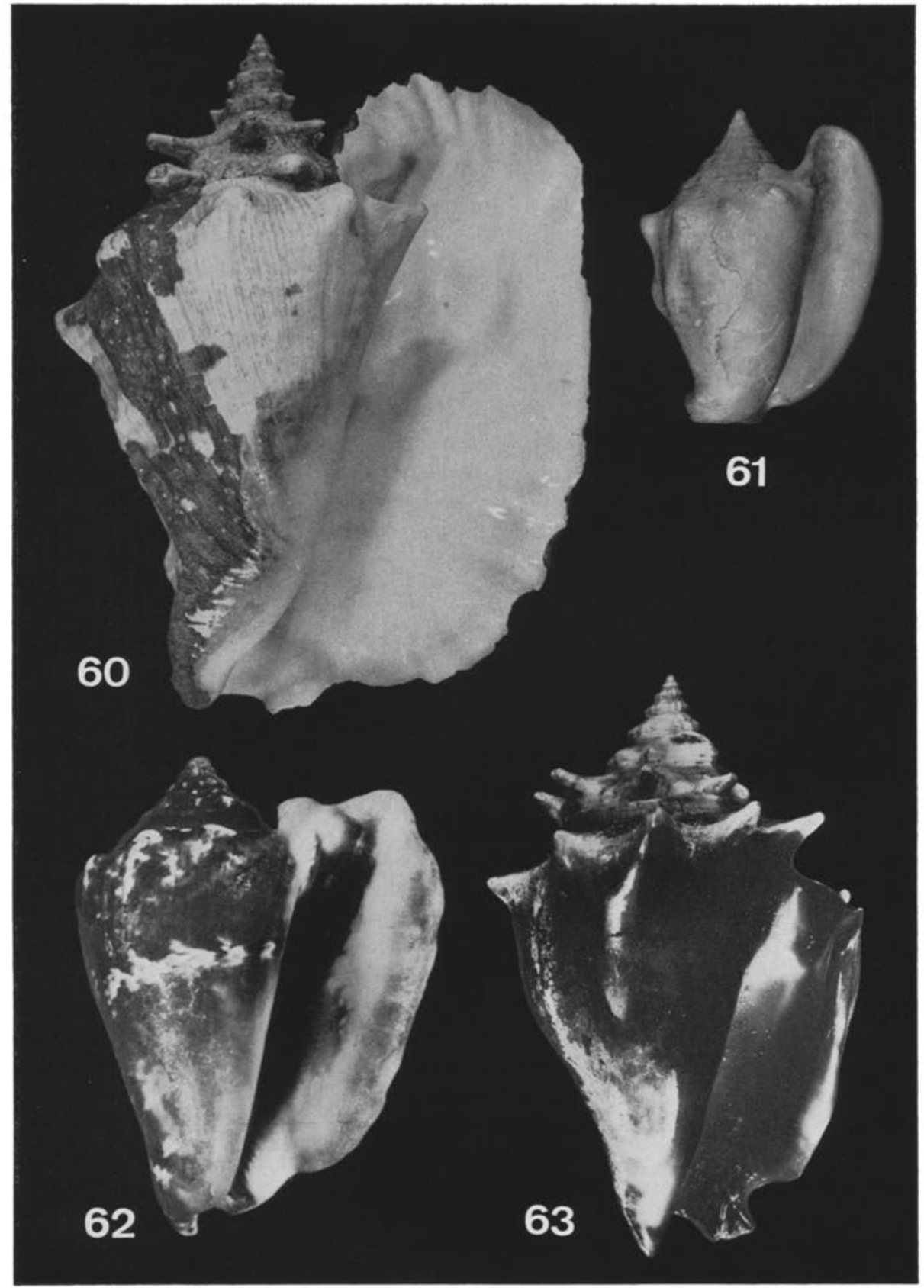

Abb. 60-63: Strombidae. 60: Strombus gigas (270 mm hoch), 61: Strombus costatus (125 mm), 62: Strombus raninus (6.4 $\mathrm{mm}), 63$ : Strombus pugilis (78 $\mathrm{mm}$ ) 


\author{
Xenophoridae \\ Xenophora conchyliophora BORN 1780 \\ (Abb. 59)
}

Höhe $50 \mathrm{~mm}$, Breite $63 \mathrm{~mm}$ (ohne Fremdmaterial). Gehäuse durch anzementierte Steine und Schalen schwer zu erkennen. Es ist flach-kegelförmig, scharf gekielt und unregelmäßig zackig. Jungtiere mit, Adulte ohne Nabel. Unterseite konkav, mit stark bogigen Anwachsstreifen. Mündung gerundet viereckig. Spindel konkav. Gehäuse, soweit nicht bewachsen, kalkweiß. Fundorte: Bahía Concha, Isla de La Aguja. Verbreitung: Südöstliche USA, Westindien.

\title{
Strombidae
}

Strombus gigas LiNné 1758

(Abb. 60)

Höhe $270 \mathrm{~mm}$, Breite $220 \mathrm{~mm}$. Gehäuse ungewöhnlich groß (bis $30 \mathrm{~cm}$ ) und dickschalig. Gewinde niedrig-kegelförmig, mit kräftigen Knoten. Mündung ziemlich weit mir fast parallelen Rändern, oben etwas erweitert, unten gebuchtet. Außenrand der Mündung erweitert, innen meist gefältelt. Oberfläche braun, Mündung innen gelblich bis orange. Periostracum blättert bei trockenen Schalen leicht ab. Auf sandigem Grund. Fundorte: Cabo de La Vela, Ensenada de Granate, Taganga, Bocachica, Islas del Rosario. Verbreitung: Bermudas, südöstliches Florida, Westindien.

\section{Strombus costatus GMEIIN 1791}

(Abb. 61)

Höhe $130 \mathrm{~mm}$, Breite $100 \mathrm{~mm}$. Gehäuse dickschalig und schwer. Gewinde kegelförmig. Umgänge mit stumpfen Höckern, die auf dem letzten Umgang besonders groß sind. Der drittletzte Höcker spornartig vorgezogen. Oberfläche mit Spiral- und Radialstreifen, zum Teil gegittert. Mündung erweitert, ihr Außenrand fast bis zur Höhe des Apex hochgezogen. Gehäuse weiß bis gelblich. Fundort: $8 \mathrm{~km}$ NE von Manaure. Verbreitung: Südöstliches Florida, Westindien.

\section{Strombus raninus GMELIN 1791}

(Abb. 62)

Höhe $66 \mathrm{~mm}$, Breite $50 \mathrm{~mm}$. Gehäuse doppelkegelförmig, Gewinde niedrig. $8 \mathrm{Um}$ gänge mit Spiralreifen und Knoten. Zwei Knoten auf der Endwindung besonders groß. Mundrand leicht erweitert, oben fast bis zur Höhe des Apex ausgezogen. Mündung oben mit Falten und gebuchtet. Grundfarbe braun, mit weißen Flecken. Fundorte: $8 \mathrm{~km}$ NE von Manaure, Ensenada Bonitogordo, Ensenada de Granate, Taganga, Bocachica, Islas del Rosario. Verbreitung: Südöstliches Florida, Westindien.

Strombus pugilis LINNÉ 1758

(Abb. 63)

Höhe $83 \mathrm{~mm}$, Breite $57 \mathrm{~mm}$. Gehäuse doppelkegelförmig, festschalig. 9 Umgänge mit Spiralreifen und Knoten, die auf den letzten beiden Umgängen zu Zacken aus- 
gezogen sind. Mündung mit fast parallelen Rändern, kaum erweitert, unten gebuchtet, innen gefältelt. Gehäuse orangerot, apical heller. Fundorte: $8 \mathrm{~km}$ NE von Manaure, $2 \mathrm{~km}$ NE von Pájaro, Camarones, Ancon, Taganga, Bocachica. Verbreitung: Südöstliches Florida, Westindien.

\section{Eratoidae}

Trivia pediculus LINNÉ 1758

(Abb. 64)

Höhe $9 \mathrm{~mm}$, Breite $11 \mathrm{~mm}$, Länge $14 \mathrm{~mm}$. Gehäuse rundlich, gewölbt. Gewinde von der Endwindung eingeschlossen. Mündung schmal, mit 16-18 äußeren Falten. Oberseite mit etwa 19 Rippen, die in der Mitte durch eine Furche getrennt sind. Oberseite graubraun bis rötlichbraun, mit 3 Paar unregelmäßigen dunkleren Flecken. Fundorte: Buritaca, Bahía Concha, Ensenada de Granate. Verbreitung: Südliches Florida, Westindien.

$$
\text { Cypraeidae }
$$

\section{Cypraea zebra LINNÉ 1758}

(Abb. 65)

Höhe $34 \mathrm{~mm}$, Breite $44 \mathrm{~mm}$, Länge $82 \mathrm{~mm}$. Schale groß, gewölbt. Gewinde ganz von der Endwindung eingeschlossen. Mündung schmal, leicht bogig, mit etwa 40 dunkelbraunen Falten jederseits. Oberlä̈che glatt, mit 4 breiten, dunkelbraunen Spiralbändern, die bei Adulten schwer erkennbar sind. Braun mit weißen Flecken, die an den Seiten dunkelbraun gefüllt sind. Fundorte: $8 \mathrm{~km} \mathrm{NE}$ von Manaure, Ensenada de Granate, Taganga, Punta de Betín, Ancon. Verbreitung: Suidöstliches Florida, Westindien.

\section{Cypraea cinerea GMELIN 1791}

(Abb. 66)

Höhe $18 \mathrm{~mm}$, Breite $21 \mathrm{~mm}$, Länge $34 \mathrm{~mm}$. Gehäuse gewölbt. Endwindung umschließt das Gewinde. Mündung schmal, leicht bogig, mit 20-30 Falten jederseits. Oberfläche glatt, hell kaffee- bis orangebraun, mit 2 helleren Spiralbändern. Fundorte: Ensenada Bonitogordo, Isla de La Aguja, Ensenada del Granate. Verbreitung: Südöstliches Florida, Westindien.

\section{Cypraea spurca acicularis GMELIN 1791}

\section{(Abb. 67)}

Höhe $14 \mathrm{~mm}$, Breite $17 \mathrm{~mm}$, Länge $25 \mathrm{~mm}$. Gehäuseform wie bei den anderen Cypraea-Arten. 16-18 weiße Falten auf jeder Seite der Mündung. Farbe weißlich, auf der Oberseite orangebraun, an den Seiten dunkelbraun gefleckt. Fundorte: Ensenada de Granate, Punta de Betín. Verbreitung: Südliches Florida, Yucatan, Westindien.

\section{Cypraea mus LINNÉ 1758}

(Abb. 68)

Höhe $30 \mathrm{~mm}$, Breite $40 \mathrm{~mm}$, Länge $58 \mathrm{~mm}$. Gehäuse gewölbt, Form wie bei den oben beschriebenen Arten. Oberfläche oft mit 1-2 Höckern. Jüngere Exemplare kaffee- 


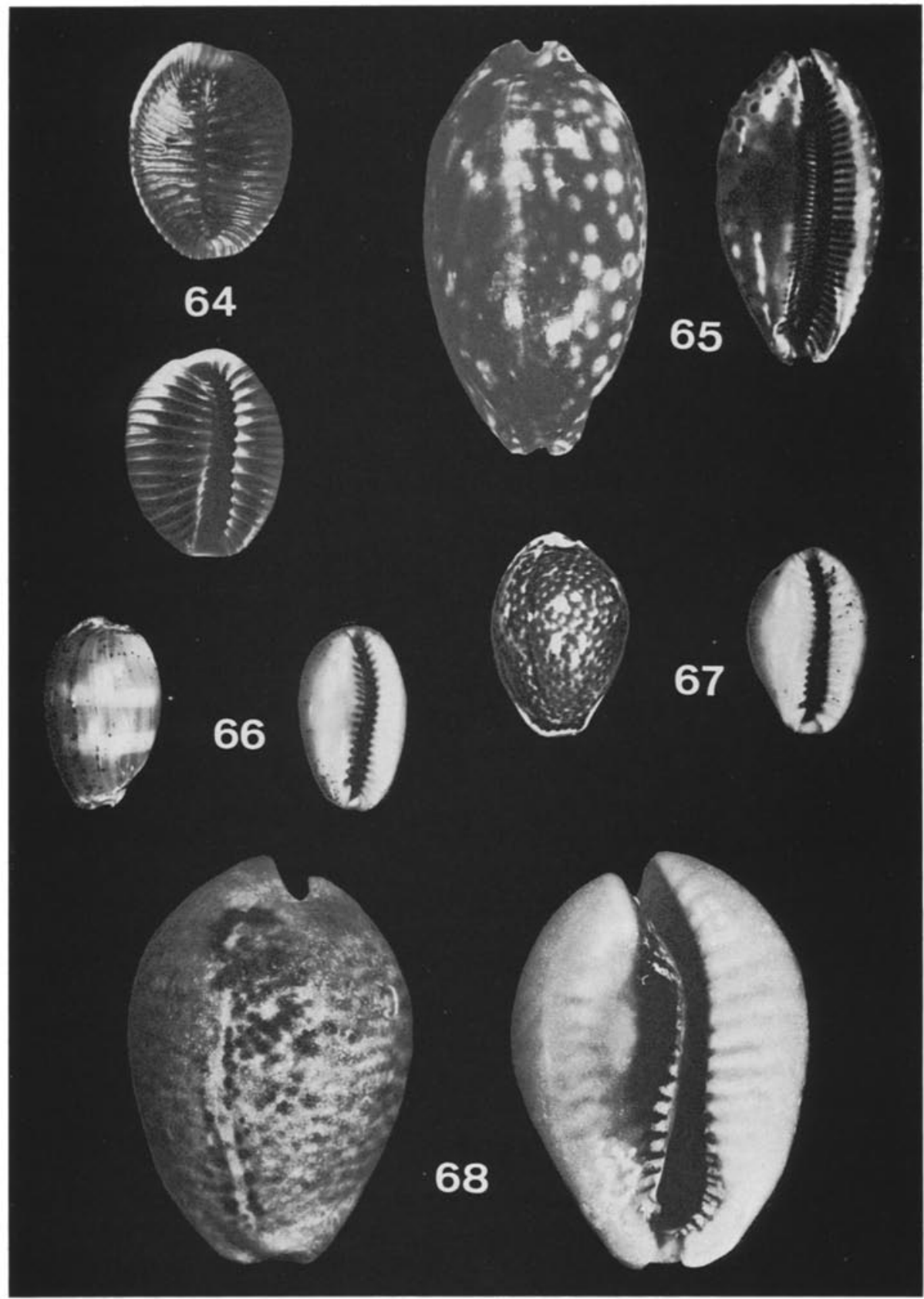

Abb. 64-68: Eratoidae, Cypraeidae. 64: Trivia pediculus (14 mm), 65: Cypraea zebra (82 mm), 66: Cypraea cinerea $(23 \mathrm{~mm}), 67$ : Cypraea spurca acicularis $(25 \mathrm{~mm}), 68$ : Cypraea mus $(54 \mathrm{~mm})$ 


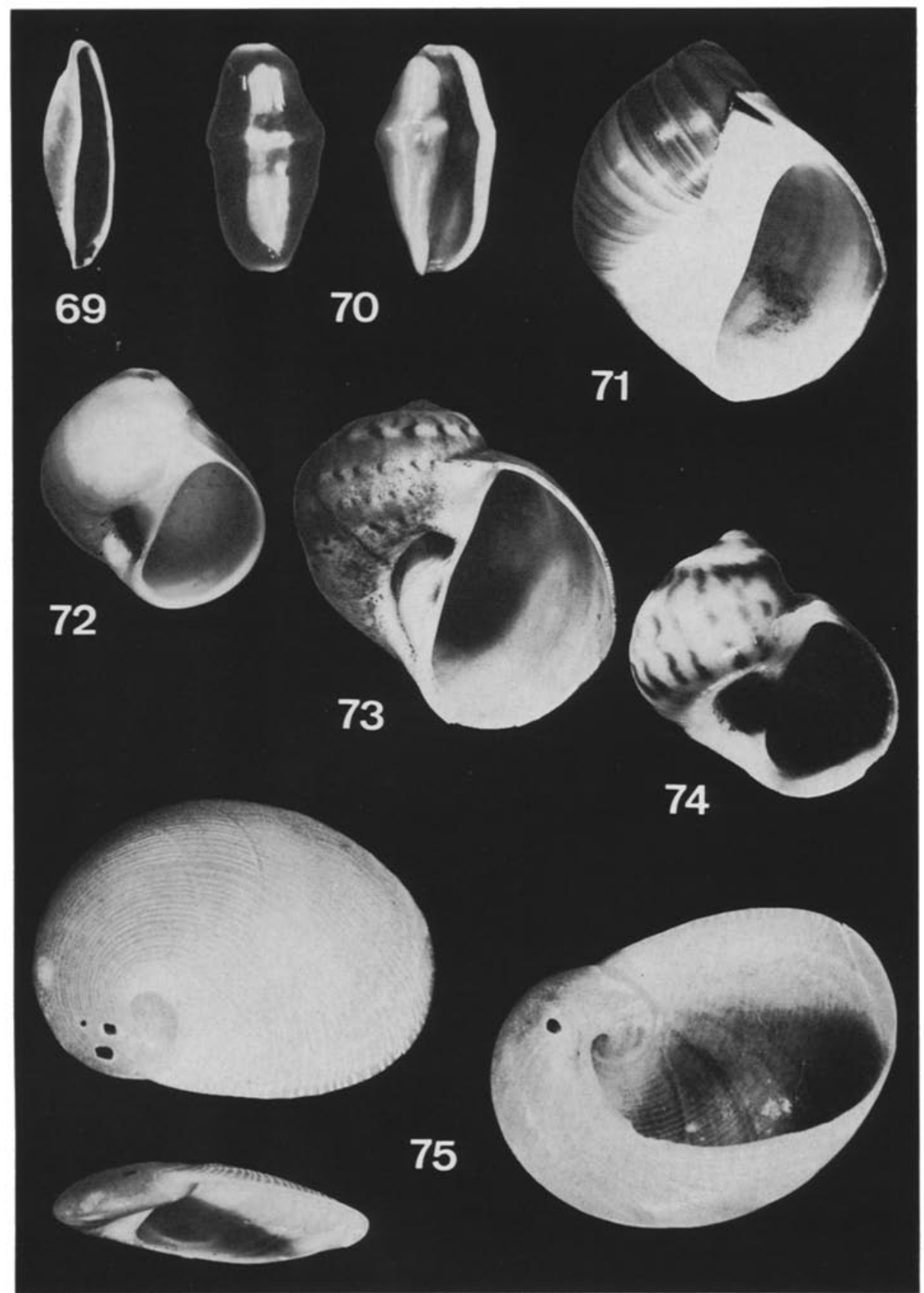

Abb. 69-75: Ovulidae, Naticidae. 69: Neosimnia acicularis (10 mm), 70: Cyphoma gibbosum $(28,5 \mathrm{~mm}), 71$ : Polinices bepaticus $(31 \mathrm{~mm}), 72$ : Polinices lacteus $(15,5 \mathrm{~mm}), 73:$ Natica canrena (39 mm), 74: Natica livida $(7 \mathrm{~mm}), 75$ : Sinum perspectivum (größter Durchmesser $20 \mathrm{~mm}, 5 \mathrm{~mm}$ hoch) 
braun, ältere graubraun, mit dunkleren, unscharfen Bändern an den Seiten, oben Gruppen dunkler Flecke, dazwischen eine hellere Furche. Fundorte: $8 \mathrm{~km}$ NE von Manaure, $2 \mathrm{~km}$ NE von Pájaro, Camarones. Verbreitung: Südliche Karibische See.

\section{Ovulidae}

\section{Neosimnia acicularis LAMARcK 1810}

(Abb. 69)

Höhe $2,5 \mathrm{~mm}$, Breite 3,4 mm, Länge 10,6 mm. Gehäuse spindelförmig, an beiden Enden zugespitzt. Gewinde von der Endwindung eingeschlossen. Mündung schmal, auf der Columellarseite von einer weißen Leiste begrenzt. Grundfarbe hellpurpurn. Am Fundort auf Gorgonarien. Fundort: Punta de Betín. Verbreitung: Südöstliche USA, Westindien.

\section{Cyphoma gibbosum LINNÉ 1758}

(Abb. 70)

Höhe $12 \mathrm{~mm}$, Breite $16 \mathrm{~mm}$, Länge $29 \mathrm{~mm}$. Gehäuse spindelförmig, mit stumpfen Enden. Rücken mit Kiel (in Spiralrichtung). Gewinde von der Endwindung umfaßt. Mündung schmal, auf einer Seite erweitert. Auf der Außenlippe ist eine Zähnelung schwach angedeutet. Oberfläche glatt, glänzend, orange mit hellerem Querband. Beim lebenden Tier Schale vom Mantel bedeckt. Mantel fleischfarben, mit eckigen schwarzen Ringen. Auf Gorgonarien lebend. Fundorte: Ensenada de Granate, zwischen Punta de Granate und Punta Las Minas, Punta de Betín. Verbreitung: Südöstliche USA, Westindien.

\section{Naticidae}

\section{Polinices bepaticus RöDING 1798}

(Abb. 71)

Höhe $31 \mathrm{~mm}$, Breite $25 \mathrm{~mm}$. Gehäuse eikegelförmig. Gewinde klein, Endwindung sehr groß. Naht flach. Mündung halbkreisförmig, mit einer Parietalschwiele, die den weiten Nabel zum Teil bedeckt. Außenrand der Mündung scharf. Oberfläche mit feinen Zuwachs- und sehr feinen Spiralstreifen. Gehäuse hell- bis orangebraun, mit schwachen, dunkelbraunen Spiralbändern. Nabel weiß. Fundorte: Buritaca, Islas del Rosario, Tolú. Verbreitung: Südöstliches Florida, Westindien.

\section{Polinices lacteus GuLding 1834}

(Abb. 72)

Höhe $16 \mathrm{~mm}$, Breite $14 \mathrm{~mm}$. Gehäuse eikegelförmig, Gewinde niedrig, Endwindung dominiert. Naht flach. Mündung halbkreisförmig. Nabel offen, von der Parietalschwiele zum Teil bedeckt. Gehäuse gelblichweiß, mit schneeweißem Spiralband unter der Naht. Fundorte: Bahía Concha, Ensenada de Granate, Islas del Rosario. Verbreitung: Südöstliche USA, Westindien. 


\section{Natica canrena LinNé 1758}

(Abb. 73)

Höhe $40 \mathrm{~mm}$, Breite $38 \mathrm{~mm}$. Gehäuse kugelig. Gewinde niedrig. Umgänge kräftig gewölbt und dadurch deutlich voneinander abgesetzt. Endwindung sehr groß. Mündung groß, halbkreisförmig. Großer, kalkiger Nabelstrang, der durch eine Rinne von der Parietalschwiele getrennt ist. Außenrand der Mündung scharf. Oberfläche glatt, mit feinen Zuwachsstreifen, nur unter der Naht stärker gestreift. Farbe und Zeichnung variabel. Grundfarbe hellbraun, mit mittelbraunen und mildigweißen Spiralbändern und dunkelbraunen, querlaufenden, gewellten und gezackten Linien. Nabelfeld weiß. Fundorte: Bahía Concha, Islas del Rosario. Verbreitung: Südöstliche USA, Westindien.

\section{Natica livida Pfeiffer 1840}

(Abb. 74)

Höhe $7 \mathrm{~mm}$, Breite $7 \mathrm{~mm}$. Gehäuse kugelig. Gewinde deutlich erhoben, tiefe Naht zwischen den gewölbten Umgängen. Endwindung dominiert. Mündung halbkreisförmig mit scharfem Außenrand. Nabel von brauner Schwiele (Callus) ausgefüllt. Gehäuse-Oberfläche glänzend, besonders unter der Naht mit deutlichen Zuwachsstreifen. Grundfarbe hellbraun, mit milchweißen und mittelbraunen Spiralbändern und unregelmäßigen, gewellten und gezackten braunen Radialstreifen. Fundort: Bahía Concha. Verbreitung: Nordkarolina bis Westindien.

\section{Sinum perspectioum SAY 1831}

(Abb. 75)

Höhe $5 \mathrm{~mm}$, maximaler Durchmesser 19,3 mm. Schale dünn und zerbrechlich. Gehäuse ohrförmig, stark abgefladht. Gewinde nicht erhoben. Naht wenig deutlich. Vier rasch zunehmende Umgänge. Ungenabelt. Mündung weit, ohrförmig, ihre Innenseite glänzend. Coltumella gebogen. Skulptur aus zahlreichen feinen, abgeflachten, leicht welligen Spirallinien, die aber nicht auf die Basis der Schale übergreifen. Schale rein weiß. Auf Sandböden in flachem Wasser. Fundort: Buritaca. Verbreitung: Südöstliche und Golf-Staaten der USA, Westindien.

\section{Cassididae}

\section{Phalium granulatum BorN 1778}

(Abb. 76)

Höhe $44 \mathrm{~mm}$, Breite $30 \mathrm{~mm}$. Gehäuse eikegelförmig. Gewinde kegelförmig mit konkaver Seitenlinie. Mündung oben spitzwinklig, unten erweitert mit kurzer, stark gebogener Rinne. Außenwand der Mündung etwas verdickt und umgeschlagen, innen gezähnt. Unteres Parietalfeld mit Kalkwarzen. Oberfläche durch Spiral- und Axialfurchen gegittert. Hellbräunlich mit in Reihen angeordneten orangebraunen, gerundet viereckigen Flecken. Fundorte: Ancon, Islas del Rosario. Verbreitung: Nordkarolina bis zum Golf von Mexiko, Westindien. 


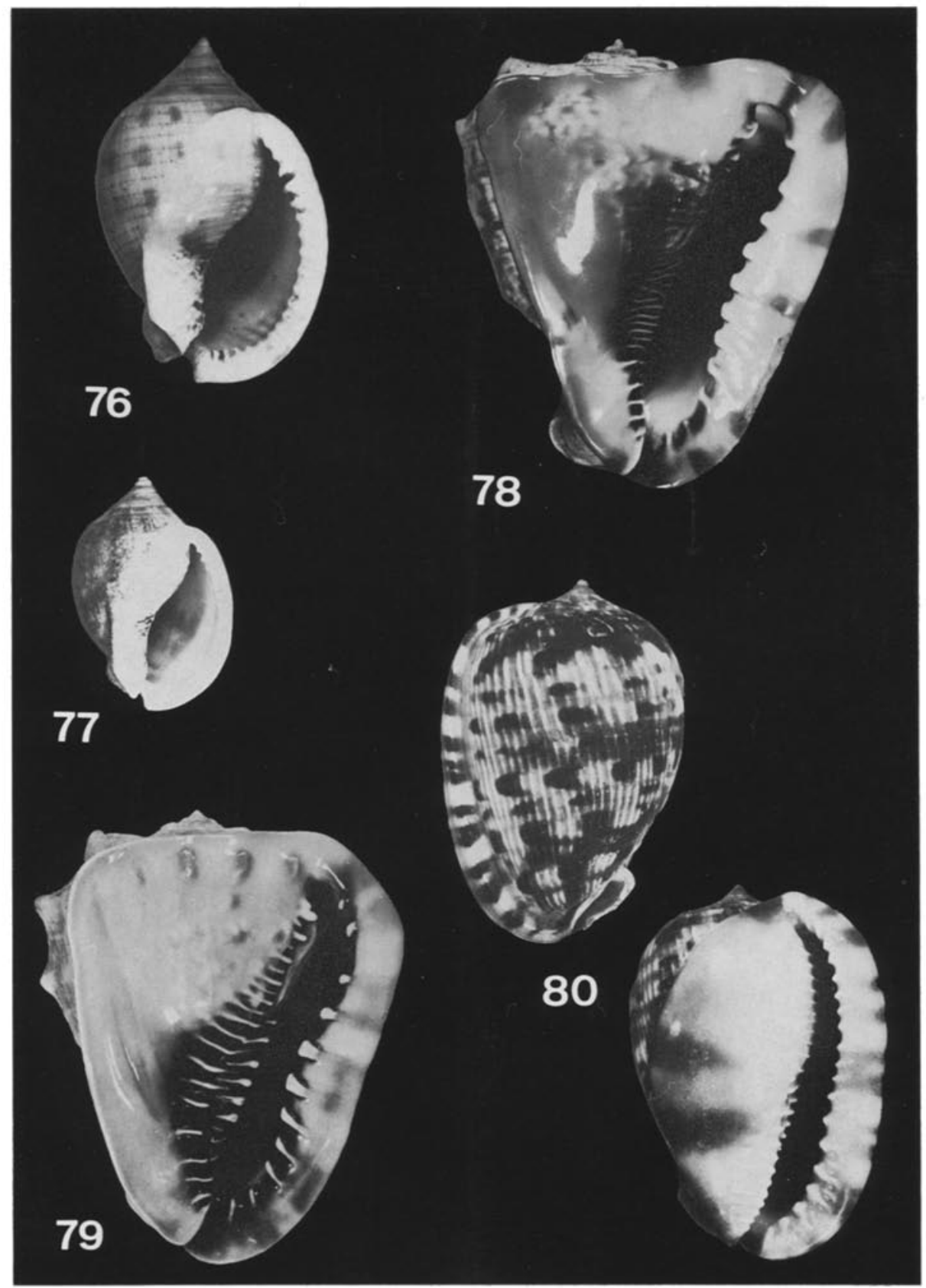

Abb. 76-80: Cassididae. 76: Pbalium granulatum (45 mm hoch), 77: Phalium cicatricosum $(31 \mathrm{~mm}), 78$ : Cassis tuberosa $(145 \mathrm{~mm}), 79$ : Cassis madagascariensis $(145 \mathrm{~mm}), 80:$ Cypraecassis testiculus $(48 \mathrm{~mm})$ 


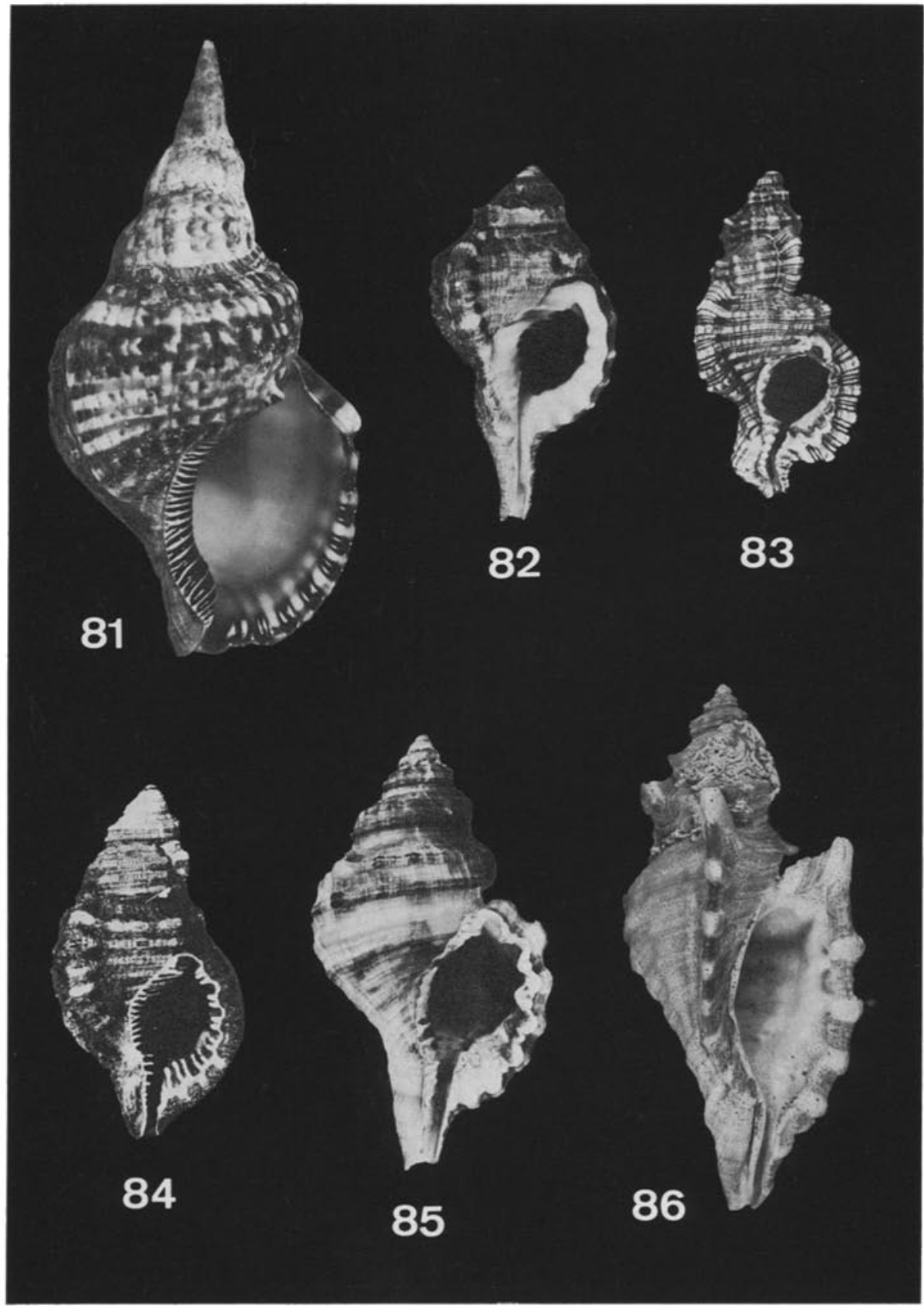

Abb. 81-86: Cymatiidae. 81: Charonia variegata (250 $\mathrm{mm}$ hoch), 82: Cymatium caribbaeum (59 mm), 83: Cymatium nicobaricum (57 mm), 84: Cymatium pileare (61 $\mathrm{mm}), 85:$ Cymatium partbenopeum $(74 \mathrm{~mm}), 86$ : Cymatium femorale $(150 \mathrm{~mm})$ 


\section{Phalium cicatricosum GMELIN 1791}

(Abb. 77)

Höhe $31 \mathrm{~mm}$, Breite $21 \mathrm{~mm}$. Gehäuseform wie bei $P h$. granulatum, Gehäuse jedoch kleiner. Außenrand der Mündung innen nur ungleichmäßig gezähnt, mittlerer Teil überwiegend glatt. Oberfläche glatter als bei Ph. granulatum: Spiralfurchen sehr schwach ausgebildet. Fleckung unregelmäßig. Fundort: Islas del Rosario. Verbreitung: Südöstliches Florida, Bermudas, Karibische See.

\section{Cassis tuberosa LnNé 1758}

(Abb. 78)

Höhe $140 \mathrm{~mm}$, Breite $115 \mathrm{~mm}$. Sehr großes, dickschaliges Gehäuse mit sehr niedrigem Gewinde. Mündung lang und schmal, Mündungsrand innen gezähnt, Spindelschwiele gefaltet. Parietalschild gerundet dreieckig. Umgänge mit deutlichen Varizen und Reihen kräftiger Knoten. Oberfläche gegittert. Mittelbraun mit dunkleren, axial laufenden, gewellten Linien. Parietalschild kaffeebraun mit dunkelbraunem Zentrum und dunkelbraunen Streifen auf der Außenwand der Mündung sowie zwischen den Zähnen. Fundorte: Ensenada Bonitogordo, Bocachica. Verbreitung: Suidöstliches Florida, Westindien.

\section{Cassis madagascariensis LAMARCK 1822}

(Abb. 79)

Höhe $150 \mathrm{~mm}$, Breite $110 \mathrm{~mm}$. Gehäuse groß, dickschalig, mit sehr niedrigem Ge. winde. Mündung lang und schmal. Mündungsrand mit breiten, weißen Zähnen. Spindelrand mit weißen Falten. Parietalschild weniger ausgeprägt dreieckig als bei C. tuberosa. Letzter Umgang mit drei Spiralreihen großer Knoten, dazwischen flachere Spiralbänder und Axialstreifen. Oberfläche cremefarben, Parietalschild rosabraun bis lachsfarben, Columellarwand besonders an der Basis dunkelbraun. Von den weißen Zähnen der Mündungswand strahlen dunkelbraune Streifen zur Außenseite der Mündung aus. Fundort: Bahía Concha. Verbreitung: Sïdöstliches Florida, Bahamas, Große Antillen.

\section{Cypraecassis testiculus LinNé 1758}

(Abb. 80)

Höhe $63 \mathrm{~mm}$, Breite $39 \mathrm{~mm}$. Gehäuse dickschalig, eiförmig, Cypraea-ähnlich. Gewinde niedrig, Endwindung dominierend. Mündung schmal und lang, Außenrand innen mit kräftigen Zähnen und Falten, Spindel mit Falten. Außenrand umgeschlagen und verdickt. Oberfläche gegittert, jedoch dominieren die axialen Leisten. Grundfarbe hellbis rötlichbraun mit dunkelbraunen, axialen, gewellten Bändern und Spiralbändern. Parietal- und äußere Mündungswand gelblich mit rosa Bändern. Fundorte: Cabo de La Vela, Ensenada Bonitogordo, Ensenada de Granate, Taganga, Punta de Betín, Morro de Gaira, Golfo de Morrosquillo. Verbreitung: Südöstliches Florida, Bermudas, Westindien. 
Cymatiidae

\section{Charonia variegata LAMARck 1816}

(Abb. 81)

Höhe $201,0 \mathrm{~mm}$, Breite $93,0 \mathrm{~mm}$. Gehäuse groß. Gewinde spitz-konisch. Apex und Embryonalschale meist abgebrochen. Bis zu 12 gerundete Umgänge. Ungenabelt. Mündung elliptisch. Außenlippe mit kurzen, meist paarigen Falten. Auf dem schokoladenbraunen Parietalschild zahlreiche weiße, weit einwärts reichende Falten. Siphonalkanal kurz und weit. Skulptur der ersten Umgänge reticulär; ab 5. postembryonalem Umgang zahlreiche breite und flache Spiralleisten, die unter der Naht deutlich schmaler sind und von feinen axialen Rippen gekreuzt werden. Varizen flach, jedoch mit scharf markierter Wachstumslinie. Färbung der ersten Umgänge rosa, der späreren aus unregelmäßigen, alternierenden sparrenförmigen, braunen und weißen Flecken. Mündung hellrosa, am Rande braun. Fundorte: Bahía Concha, Isla de La Aguja, Bocachica. Verbreitung: Mittelmeer, Kanarische und Cap Verdische Inseln, Bahamas, Lower Florida Keys, Westindien bis Brasilien.

\section{Cymatium caribbaeum CLENCH \& T'URNer 1957}

(Abb. 82)

Höhe $89,0 \mathrm{~mm}$, Breite $48,0 \mathrm{~mm}$. Schale schwer. Gewinde kurz. Apex und die glatte Embryonalschale meist korrodiert. 5-6 bauchig-geschulterte Umgänge. Ungenabelt. Mündung oval, Außenlippe mit 7 gerundeten Zähnen, deren mittlere bei jüngeren Exemplaren paarige Spitzen tragen. Parietalschild mit 7 deutlichen Falten, zwischen denen feinere, nicht bis zum Rand reichende zu erkennen sind. Siphonalkanal lang, leicht nach dorsal und links gekurvt. Skulptur aus 6-7, im oberen Teil der Umgänge knotigen Spiralleisten, mit zahlreichen feinen Spirallinien in den Zwischenfeldern. Die Wachstumslinien bilden eine feine reticuläre Skulpturierung. 3 Varizen. Schale gelb- bis rötlichbraun, auf den Varizen alternierende weiße Bänder. Periostracum hellbraun, mit zu Härchen ausgezogenen axialen Lamellen. Mündungsrand orange, Mündung innen blauweiß. Parietalschild violettweiß mit einem schokoladenbraunen Fleck. Fundorte: $8-10 \mathrm{~km}$ NE von Manaure, Bocachica. Verbreitung: Bermudas, Südflorida, Westindien, Brasilien.

\section{Cymatium nicobaricum RöDING 1798}

(Abb. 83)

Höhe $57,0 \mathrm{~mm}$, Breite $28,0 \mathrm{~mm}$. Gewinde hoch. Die 6 Umgänge gegeneinander abgewinkelt. Nabel bedeckt oder als kurzer Schlitz zwischen Columella und Parietalschild. Mündung rund-oval. Außenlippe bei Varizenbildung stark verdickt, auf ihrer Innenseite mit 6, teilweise paarigen Zähnen. Siphonalkanal kurz, eng und wie die Columella nach dorsal und rechts gekurvt. Auf den Umgängen 6 Spiralleisten, die zwischen den Varizen 5 Knoten tragen. 5-8 Varizen. Schale aschgrau, Mündung orange, bei juvenilen Exemplaren mit braunen und weißen Spiralbändern. Fundorte: Bahía Concha, Islas del Rosario. Verbreitung: Madeira, Kanarische Inseln, Bermudas, Florida, Westindien, Bahia (Brasilien); Hawaii, Marquesas, Südjapan, Ostindien bis Mauritius. 


\section{Cymatium pilleare LINNÉ 1758}

(Abb. 84)

Höhe $117,0 \mathrm{~mm}$, Breite $61,0 \mathrm{~mm}$. Schale schwer und stark skulpturiert. Apex und Embryonalschale meist korrodiert. 6-7 postembryonale Umgänge. Ungenabelt. Mündung elliptisch. Außenlippe stark verdickt, auf der Innenseite mit 7 Zähnchenpaaren, die sich nach innen als Falten fortsetzen. Auf dem dunkelbraunen Parietalschild zahlreiche unregelmäßige weiße Lamellen. Siphonalkanal kurz und leicht nach dorsal gebogen. Skulptur aus zahlreichen, unterschiedlich dicken und häufig geknoteten Spiralleisten, gekreuzt von feinen, geschweiften Wachstumslinien. 3-5 Varizen. Schale braun bis graubraun, mit 1-2 hellen, auf den Varizen sehr deutlichen Bändern. Periostracum goldbraun, mit zahlreichen Härchen und axialen Lamellen. Fundorte: Cabo de La Vela, Islas del Rosario. Verbreitung: Im Westatlantik von Florida ïber Westindien bis Brasilien, Bermudas. Im Indo-Pazifik von Hawaii, den Ryukyu-Inseln über Ostindien bis Ostafrika.

\section{Cymatium parthenopeum VoN SALIS 1793}

(Abb. 85)

Höhe $120,0 \mathrm{~mm}$, Breite $70,0 \mathrm{~mm}$. Schale stark skulpturiert. Apex und die glatte Embryonalschale meist korrodiert. 7 postembryonale, gerundete, gegeneinander scharf abgesetzte Umgänge, die durch Spiralskulptur geschultert erscheinen. Nabel schlitzförmig oder völlig yom Parietalschild verdeckt. Mündung etwa elliptisch. Außenlippe bei Varizenbildung stark verdickt, innen mit 6-7 Zähnchenpaaren unter den Spiralrinnen. Auf dem rötlichbraunen Parietalschild zahlreiche unregelmäßige, weiße Leisten. Siphonalkanal mäßig lang, leicht nach dorsal gebogen. Letzter Umgang mit 5-6, übrige Umgänge mit 2 breiten Spiralleisten, die im Verein mit feinen Wachstumslinien eine reticuläre Skulptur bilden. Einschließlich des Mündungsrandes nicht mekr als 2 flache Varizen. Schale gelb- bis rötlichbraun mit helleren Bändern. Fundort: Pájaro. Verbreitung: Westliches Mittelmeer, Azoren, Südafrika, Bermudas, Florida, Westindien, Brasilien, Japan, nördliches Neu-Seeland, Ostaustralien, Ostafrika.

\section{Cymatium femorale LINNÉ 1758}

(Abb. 86)

Höhe $190,0 \mathrm{~mm}$, Breite $104,0 \mathrm{~mm}$. Schale dick und schwer, $8-9$ geschulterte Umgänge. Nabel schlitzförmig. Mündung ohrförmig. Die Varize eine breit ausgezogene Außenlippe bildend, die bei ausgewachsenen Exemplaren 4 große, gerundete Zähne trägt. Siphonalkanal mäßig lang, eng, deutlich nach dorsal gebogen. Parietalschild glatt, mit nur schwach erhobenen Falten im inneren Teil. Skulptur aus 6-7 starken Spiralleisten, in den $Z$ wischenfeldern feinere Spirallinien. Von den 5 Varizen die letzten 2-3 blattartig, an der Schulter nach oben spitz-dreieckig ausgezogen. Schale hellbraun, auf den Varizen mit alternierenden weißen und braunen Bändern. Fundorte: Cabo de La Vela, 8-10 km NE von Manaure, $2 \mathrm{~km}$ NE von Pájaro. Verbreitung: Bermudas, Südost-Florida, Westindien bis Bahia (Brasilien). 
Bursidae

Bursa cubaniana OrBIGNY 1842

(Abb. 87)

Höhe $63 \mathrm{~mm}$, Breite $35 \mathrm{~mm}$. Gehäuse turmförmig, seitlich abgeflacht. Kräftige Varizen, die übereinander angeordnet sind und so zwei axiale Wülste auf dem Gehäuse bilden. Knotentragende Spiralleisten. Mündung oval mit einer oberen Rinne und einem unteren kurzen Kanal. Außenrand der Mündung innen gezahnt, Spindelschwiele mit Falten. Gehäuse mittelbraun, mit weißen Spiralbändern und Knoten. Fundorte: Bahía Concha, Ensenada de Granate, Islas del Rosario. Verbreitung: Suidöstliches Florida, Westindien.

\section{Bursa corrugata PERRY 1811}

(Abb. 88)

Höhe $40 \mathrm{~mm}$, Breite $23 \mathrm{~mm}$. Gehäuseform wie bei $B$. cubaniana. Oberfläche mit zwei Reihen besonders kräftiger Knoten. Die Spiralreifen haben an den mündungsnahen Varizen die Form dicker Wülste. Die Varizen der letzten Umgänge stehen nicht genau übereinander. Parietalschild mit Falten, Außenrand der Mündung gezähnt. Fundorte: Punta de Betín, Islas del Rosario. Verbreitung: Südöstliches Florida, Karibische See.

\section{Tonnidae}

\section{Tonna maculosa DrLLWYN 1817}

(Abb. 89)

Höhe $71,0 \mathrm{~mm}$, Breite $51,0 \mathrm{~mm}$. Gewinde stumpf-konisch. Naht deutlich und etwas eingetieft. 6 bauchige, rasch zunehmende Umgänge. Nabel eng und tief. Mündung groß, suboval. Außenlippe scharf und wellig, an der Básis etwas verbreitert. Columella stark gekurvt, mit einem weißen Callus den Nabel teilweise bedeckend. Siphonalkanal kurz und weit. Die ersten Umgänge glatt, die späteren mit zahlreichen breiten, abgefladiten Spiralleisten, die von unregelmäßigen Wachstumslinien gekreuzt werden. Manche Exemplare mit einer reticulären Skulptur. Die ältesten Umgänge kaffeebraun, die übrige Schale hellbraun mit weißen Flecken. Außenlippe kaffeebraun. Fundorte: Cabo de La Vela, Ensenada Bonitogordo, Ensenada de Granate, Islas del Rosario. Verbreitung: Von Südflorida über Westindien bis Brasilien.

\section{Tonna galea LinNé 1758}

$$
\text { (Abb. 90) }
$$

Höhe $105,0 \mathrm{~mm}$, Breite $80,0 \mathrm{~mm}$. Schale kugelig. Gewinde mäßig erhoben. Naht weit und tief gefurcht. 7 bauchige, rasch zunehmende Ungänge. Nabel tief. Mündung groß und ohrförmig. Columella spiralig gedreht, mit einer breiten, axialen Erhebung, die bis zum kurzen und weiten Siphonalkanal reicht. Ausgewachsene Exemplare mit dünnem Parietalschild. Die ersten Umgänge glatt und kaffeebraun, die übrigen mit zahlreichen abgeflachten, unterschiedlich breiten Spiralleisten und hellbraun gefärbt. Außenlippe dunkler braun. Fundorte: Cabo de La Vela, 8-10 km NE von Manaure. 


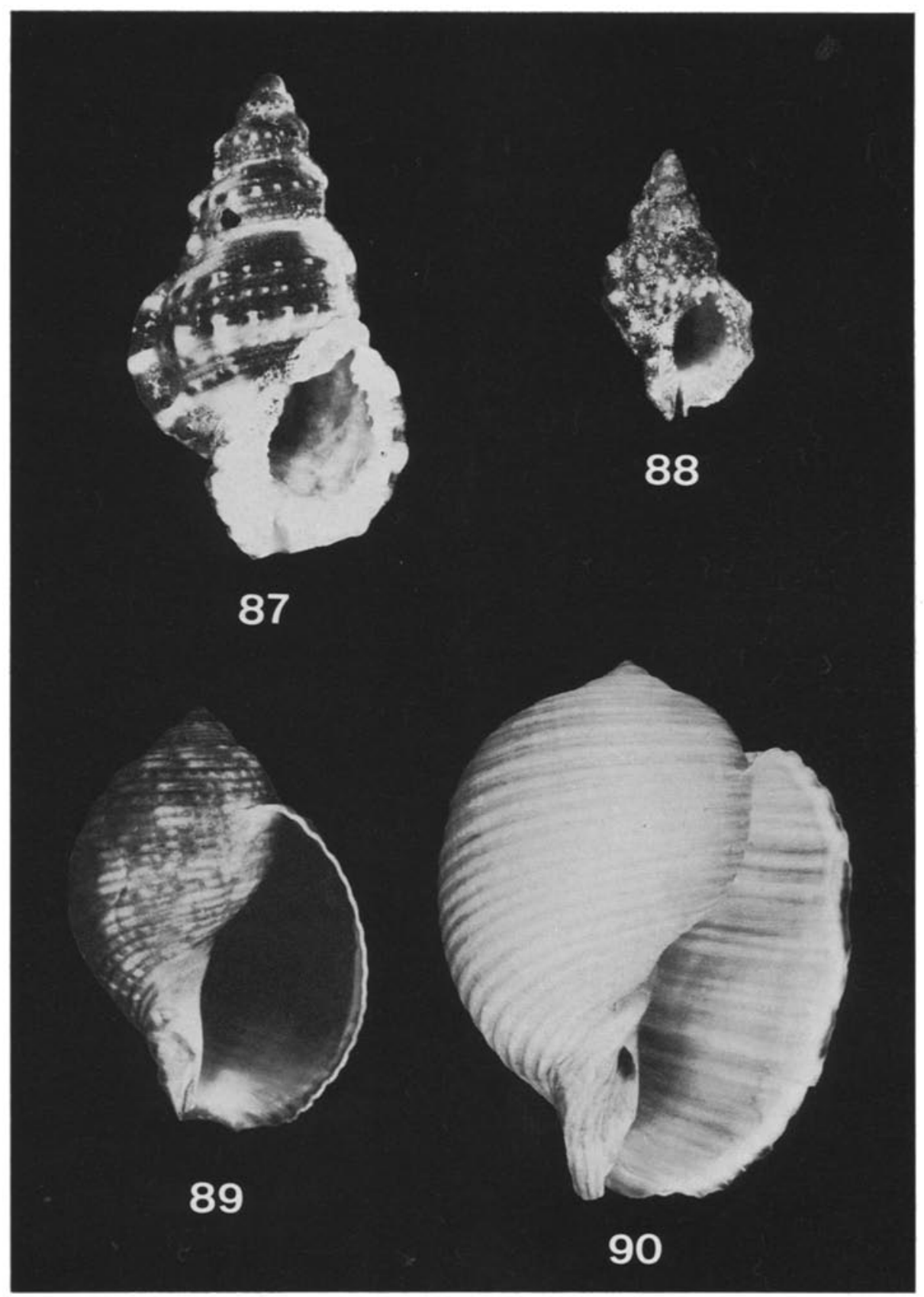

Abb. 87-90: Bursidae, Tonnidae. 87: Bursa cubaniana (63 $\mathrm{mm}$ hoch), 88: Bursa corrugata $(35 \mathrm{~mm}), 89$ : Tonna maculosa $(55 \mathrm{~mm})$, 90: Tonna galea $(110 \mathrm{~mm})$ 


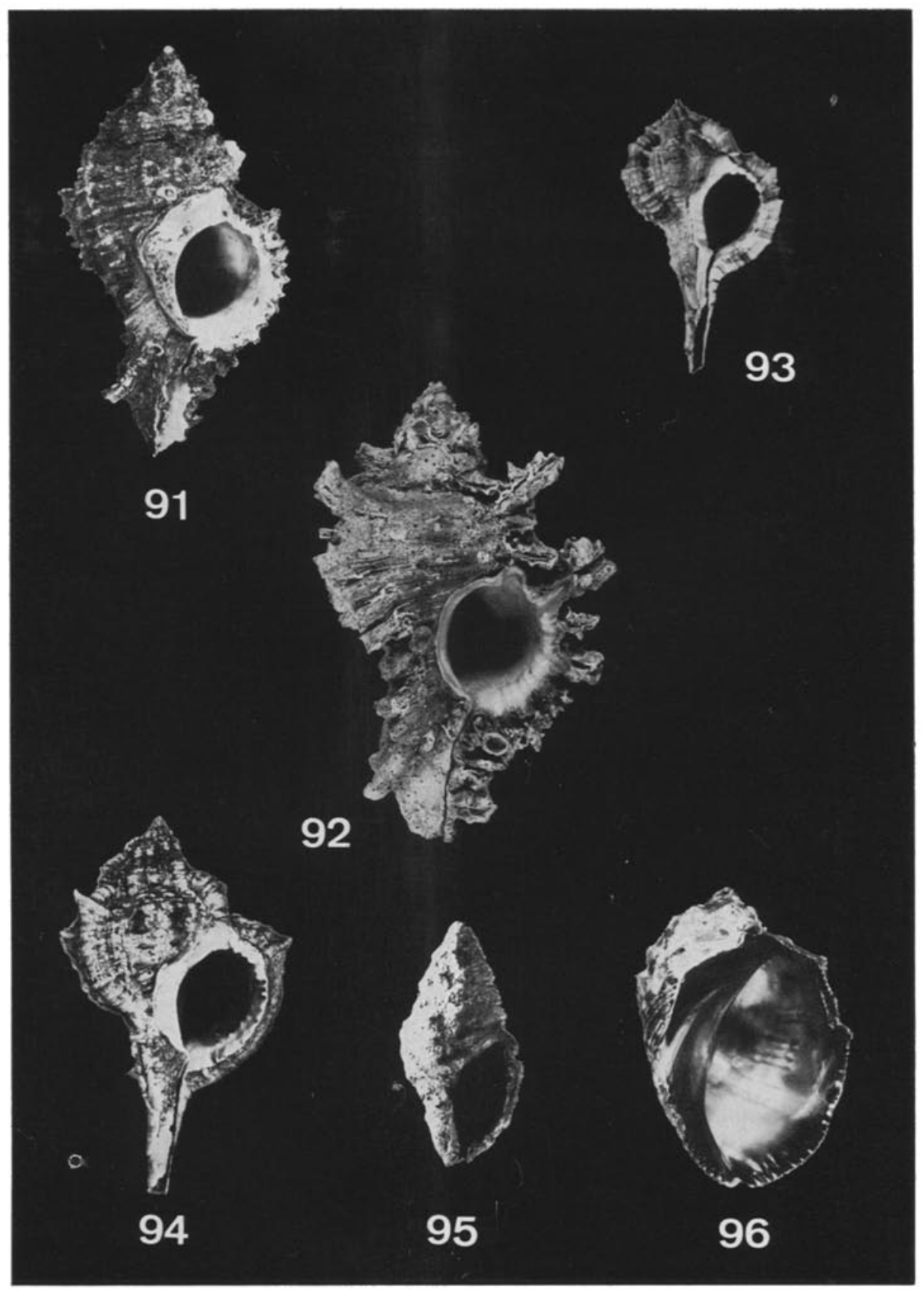

Abb. 91-96. Muricidae. 91: Murex pomum (81 mm hoch), 92: Murex brevifrons (100 mm), 93: Murex roodringi (37 mm), 94: Murex recurvirostris rubidus $(48 \mathrm{~mm}), 95:$ Drupa nodulosa (11 $\mathrm{mm}), 96:$ Purpura patula $(60 \mathrm{~mm})$ 
Verbreitung: Mittelmeer, Afrika südlich bis Spanisch Guinea; von North Carolina bis Trinidad; Hawaii; von Japan über Südostindien bis zum Indischen Ozean.

\section{Muricidae}

\section{Murex pomum GMELIN 1791}

(Abb. 91)

Höhe 91,0 mm, Breite $81,0 \mathrm{~mm}$. Schale dick und schwer. 7-9 stark gewölbte Umgänge. Mündung rundoval, Außenlippe gezähnt, Parietalschild mit kurzen, unregelmäßigen Leistchen. Siphonalkanal kurz, breit, dorso-ventral abgeflacht und bis auf eine mäßig breite Rinne abgedeckt. Varizen schräg untereinanderstehend, ohne Stacheln, aber mit krättigen Knoten. Zwischen den Varizen 1-2 axiale Knoten. Auf dem letzten Umgang 6, auf den übrigen 3 Spiralleisten und zahlreiche feine Spirallinien in den Zwischenfeldern. Schale cremefarben bis braun, Mündung elfenbeinfarben bis gelb, mit schokoladebraunen Flecken an der Außenlippe. Parietalschild wie Außenlippe gefärbt; Siphonalkanal braun. Operculum nicht verkalkt, dick und dunkelbraun, auf der Innenseite mit einem glatten sichelförmigen und einem durch unregelmäßige Linien skulpturierten ovalen Areal. Fundorte: $8-10 \mathrm{~km}$ NE von Manaure, Isla Barú, Islas del Rosario. Verbreitung: Südostküste USA, Westindien.

\section{Murex brevifrons LAMARCK 1822}

(Abb. 92)

Höhe $124,0 \mathrm{~mm}$, Breite $60,0 \mathrm{~mm}$ (ohne die Stacheln). Schale dick und schwer. Naht deutlich. Umgänge kräftig gewölbt. Mündung oval. Siphonalkanal mäßig lang, leicht nach links weisend, dorso-ventral abgeflacht und bis auf einen schmalen Schlitz abgedeckt. Varizen in 3 schrägen Axialreihen, mit starker Stachelbewehrung. Die Stacheln hohl, offen und nach hinten gebogen; der Schulterstachel am längsten. Zwischen den Varizen je ein axial rippenartig verlängerter Knoten. Auf den Umgängen zahlreiche feine Spirallinien, überlagert von flachen, auf den Varizen zu den Stacheln ausgezogenen Spiralleisten. Gehäuse cremefarben bis braun, mit purpurnen Bändern zwischen den Spiralleisten. Fundorte: Cabo de La Vela, 8-10 km NE von Manaure, $2 \mathrm{~km} \mathrm{NE}$ von Pájaro, Punta de Betín. Verbreitung: Lower Florida Keys, Westindien bis zur Amazonas-Mündung.

\section{Murex woodringi Clench \& Farfante 1945}

(Abb. 93)

Höhe $42,0 \mathrm{~mm}$, Breite 26,5 mm. Gewinde spitz-konisch, letzter Umgang stark erweitert. Mündung oval. Außenlippe mit 9-10 Zähnchen. Parietalcallus im oberen Drittel dem Umgang anliegend, darunter lamellenartig abstehend; mit zahlreichen welligen Leisten. Siphonalkanal lang, eng und bis auf schmalen Schlitz abgedeckt. Varizen in 3 Reihen axial angeordnet, $z$ wischen ihnen jeweils 1-3 axiale Knotenreihen. Auf den Umgängen und der Dorsalseite des Siphonalkanals zahlreiche feine Spiralleisten, gekreuzt von axialen Runzeln. Gehäuse gelblichbraun bis grau, mit spiraligen braunen Flecken oder Linien. Operculum nicht verkalkt, elliptisch, dunkelbraun. Fundort: Bahía Concha. Verbreitung: Jamaica, Puerto Rico, Nordküste Südamerikas. 


\section{Murex recurvirostris rubidus $\mathrm{F}$. C. BAKER 1897}

(Abb. 94)

Höhe 55,0 mm, Breite 30,5 mm. Gewinde kurz. Naht deutlich. Letzter Umgang rasch zunehmend. Mündung relativ klein, oval, zur Basis etwas zugespitzt. Außenlippe fein gezähnt, in Form einer scharfen Lamelle vor der letzten Varize. Parietalschild lamellenförmig von der Columella abstehend, mit unregelmäßigen Falten. Siphonalkanal sehr lang, schmal, leicht dorsal gebogen und bis auf einen Schlitz abgedeckt. Varizen in 3 Reihen, mehr oder weniger untereinanderstehend, mit einem kurzen Stachel auf der Schulter. Zwischen 2 Varizen 3 axiale Knotenrippen. Umgänge und Basis mit feinen Spiralleisten und welligen Axialrippen. Gehäuse cremefarben bis graubraun, die feinen Spiralleisten des letzten Umganges bräunlich. Mündung blauweiß. Operculum nicht verkalkt, tropfenförmig und hornbraun. Fundort: Punta de Gaira. Verbreitung: Florida, Bahamas, Puerto Rico.

\section{Drupa nodulosa C. B. ADAMs 1845}

(Abb. 95)

Höhe 13,5 mm, Breite 7,5 mm. Gehäuse spindelförmig. Naht sehr undeutlich, zumal Schale häufig mit Kalkalgen inkrustiert. Mündung schmal, kommaförmig. Außenlippe wulstartig, auf Innenseite mit 4 weißen Zähnchen, die beiden oberen am stärksten. Siphonalkanal kurz. Umgänge mit kleinen, sowohl in axialen als auch spiraligen Reihen angeordneten Knoten. Gehäuse braunschwarz, Mündung blauweiß bis purpurn. Fundorte: Ensenada de Granate, Punta de Betín. Verbreitung: Südliches Florida, Bahamas, Westindien bis Brasilien.

\section{Purpura patula LinNé 1758}

(Abb. 96)

Höhe $80,0 \mathrm{~mm}$, Breite $54,0 \mathrm{~mm}$. Gewinde kurz. Naht wenig deutlich. Der letzte der 4-51/2 Umgänge 9-10/11 der Schalenhöhe einnehmend. Ungenabelt. Mündung sehr groß, weit, oval. Außenlippe nicht verdickt, gezähnt. Columella gekurvt. Parietalcallus breit, nach unten sich verjüngend. An Spitze und Basis der Mündung je ein flacher Siphonalkanal. Letzter Umgang mit 6 Spiralreihen spitzer Knoten, die bei sehr großen Exemplaren weniger prominent sind als bei jüngeren. Zwischen den Knotenreihen Spirallinien. Schale grau oder graubraun. Mündung bei Juvenilen schokoladenbraun, bei Adulten im unteren Teil mit lachsfarbenen Bändern. Columella lachsfarben, in der oberen Hälfte mit schokoladebraunem Rand. Operculum nicht verkalkt, ohrförmig, dunkelbraun. Sehr häufig in der Brandungszone des Felslitorals. Fundorte: Cabo de La Vela, Bahía Concha, Isla de La Aguja, Ensenada de Granate, zwischen Punta de Granate und Punta Las Minas, Punta de Betín, Morro de Gaira. Verbreitung: Südostflorida, Westindien.

\section{Thais rustica LAMARCK 1822}

(Abb. 97)

Höhe 32,0 mm, Breite 20,5 mm. Gewinde konisch. Naht wenig deutlich. Die 5-6 Umgänge durch Knotenreihen geschultert. Ungenabelt. Mündung oval. Außenlippe 
mäßig dick und fein gezähnt, die Zähnchen nach innen als feine Spiralleisten verlängert. Columella dick, fast gerade und bis auf eine im oberen Teil einwärts laufende Leiste glatt. Siphonalkanal kurz und breit. Analkanal kurz und undeutlich. Auf dem letzten Umgang 2 Reihen spiralig angeordneter Knoten, auf den übrigen nur 1 Knotenreihe. Außer den Knoten Schale durch feine Spiral- und Wachstumslinien skulptiert. Schale gelb- bis aschgrau, junge Exemplare mit dunkelbraunen Flecken auf orangegelbem Grund. Mündung und Columella weiß, Außenlippe kaffeebraun, bei manchen Exemplaren mit durchscheinenden braunen und orangegelben Bändern. Relativ selten. Fundorte: Bahía Concha, Ensenada Bonitogordo. Verbreitung: Südflorida, Westindien bis Brasilien.

\section{Thais haemostoma floridana CONRAD 1837 \\ (Abb. 98)}

Höhe $71,0 \mathrm{~mm}$, Breite $45,0 \mathrm{~mm}$. Gehäuseform variabel von breit-gedrungen bis spindelförmig. Naht undeutlich. 6-7 leicht geschulterte Umgänge. Ungenabelt. Mündung groß, oval. Außenlippe kaum verdickt, gezähnt, die Zähnchen als feine Leisten nach innen laufend. Columella fast gerade, durch einen glatten Callus verdickt, nahe dem Analkanal mit kräftiger, nach innen laufender Leiste. Siphonalkanal kurz und breit. Skulptur aus zahlreichen feinen Spirallinien und kreuzenden Wachstumslinien. Manche Schalen mit einer Spiralreihe stumpfer Knoten auf der Schulter, zu der gelegentlich eine zweite Knotenreihe auf der Mitte des letzten Umganges hinzukommen kann. Schale aschgrau, gelegentlich mit purpurbraunen Flecken. Mündung lachsfarben, zwischen den Zähnen der Außenlippe schokoladenbraun. Operculum nicht verkalkt, relativ dünn, rötlichbraun. Nicht sehr häufig; unter Steinen und Korallblöcken im Flachwasserbereich. Fundorte: Camarones, Ensenada Bonitogordo, Punta de Betín, Ancon, Punta de Gaira. Verbreitung: North Carolina und gesamtes Karibisches Meer.

\section{Thais deltoidea LAMARCK 1822}

(Abb. 99)

Höhe 49,0 mm, Breite 39,0 mm. Schale dick und schwer, oft dick mit krustenbildenden Kalkalgen besetzt, so daß Naht und Zahl der Umgänge nicht feststellbar sind. Gewinde weniger als $1 / 3$ der Höhe. Ungenabelt. Mündung oval. Außenlippe unmittelbar hinter dem fein gezähnten Rand stark verdickt. Columella dick, fast gerade, an der Basis einen Grat bildend, hinter dem der Siphonalkanal tief unter die Columella greift. Parietalcallus glatt und glänzend. Skulptur in Form von 1, seltener 2 Spiralreihen großer, stumpfer Stacheln auf der Schulter. Schale grau, bei jüngeren Exemplaren mit braunen Bändern oder Flecken. Mündung weiß, Parietalcallus violett getönt. Am Rand der Außenlippe ein schmaler brauner Streifen. Operculum nicht verkalkt, schwarzbraun, auf der Innenseite mit glänzendem Randwulst. Häufig im Felslitoral. Fundorte: Bahía Concha, Isla de La Aguja, Ensenada de Granate, Punta Las Minas, Punta de Betín, Bocachica. Verbreitung: Bermudas, Bahamas, von Florida über Westindien bis Brasilien. 


\section{Coralliophila abbreviata LAMARCF 1816}

(Abb. 100)

Höhe $26 \mathrm{~mm}$, Breite $22 \mathrm{~mm}$. Gehäuse rundlich mit kurz kegelförmigem Gewinde. Ungänge mit einer gerundeten Schulter. Letzter Umgang dominiert. Mündung eiförmig mit offenem Kanal am unteren Ende. Außenrand der Mündung innen mit Leisten. Oberfläche mit Spiralreifen und wulstigen axialen Rippen. Nabel kanalartig verlängert. Gehäuse grau- bis gelblichweiß. Auf oder in der Nähe von Korallen. Fundorte: Ensenada de Granate, Taganga, Bocachica. Verbreitung: Südöstliches Florida, Westindien.

\section{Coralliopbila caribaea Aввотт 1958}

(Abb. 101)

Höhe $23 \mathrm{~mm}$, Breite $15 \mathrm{~mm}$. Gewinde höher kegelförmig als bei $C$. abbreviata, letzter Umgang relativ kleiner, schwach geschultert. Außenrand der Mündung gezackt Oberfläche mit axialen Wülsten, die auf der Endwindung wenig in Erscheinung treten, und mit zahlreichen schuppig-knotigen Spiralreifen unterschiedlicher Stärke. Gehäuse grauweiß bis hell-schmutzigbraun. Mündung weiß mit Purpur. Fundorte: Bahía Concha, Ensenada Bonitogordo, Ensenada de Granate (in Schalen von Ostrea frons am Spülsaum), Punta de Betín. Verbreitung: Südöstliches Florida, Westindien.

\section{Columbellidae}

\section{Columbella mercatoria LINNÉ 1758}

(Abb. 102)

Höhe $17 \mathrm{~mm}$, Breite $11 \mathrm{~mm}$. Gehäuse rundlich doppelkegelförmig mit niedrigem Gewinde. Umgänge gewölbt, leicht geschultert. Mündung schmal, bogig, etwa $2 / 3$ der Gehäusehöhe, gezähnt; Außenwand verdickt. Spindelschwiele mit 6-8 weißen Warzen. Oberfläche mit breiten, abgeflachten Spiralreifen. Auf gelblichweißem Grund spiralig angeordnete braune Flecke. Fundorte: Bahía Concha, Ensenada Bonitogordo, Ensenada de Granate, Morro de Gaira, Punta La Loma. Verbreitung: Südöstliches Florida, Westindien.

\section{Mazatlania aciculata LAMARCK 1822}

(Abb. 103)

Höhe $18 \mathrm{~mm}$, Breite $6 \mathrm{~mm}$. Gehäuse turmförmig mit schwach geschulterten Windungen. Apex spitz. Windungen in der oberen Hälfte mit Axialrippen. Endwindung im unteren Drittel spiralig gefurcht. Außerdem sehr feine Axial- und Spirallinien. Grundfarbe hellbraun. Ein violettbraunes Spiralband im gerippten Teil der Umgänge. Im unteren Teil der Endwindung ein breites Spiralband. Dazu zarte rotbraune Axialstreifen. Fundorte: Rodadero, Bocagrande. Verbreitung: Westindien.

\section{Anachis sparsa ReEve 1859}

(Abb. 104)

Höhe $12 \mathrm{~mm}$, Breite $5 \mathrm{~mm}$. Gehäuse spindelförmig, Umgänge schwach gewölbt. Mündung schmal, unten mit kurzer, breiter Rinne. Außenrand der Mündung innen 


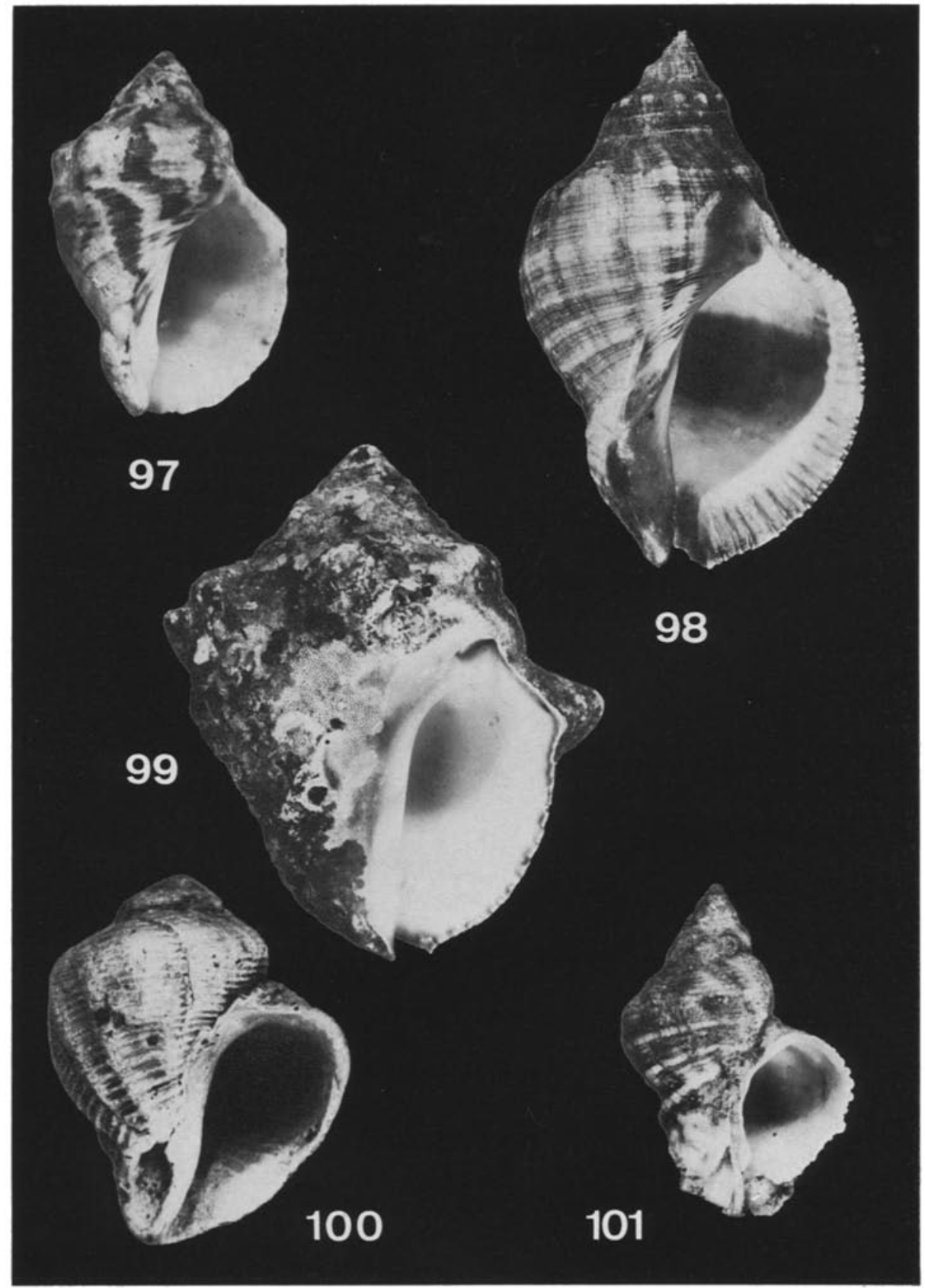

Abb. 97-101: Muricidae, Magilidae. 97: Thais rustica (24 $\mathrm{mm}$ hoch), 98: Thais haemostoma floridana $(70 \mathrm{~mm})$, 99: Thais deltoidea $(43 \mathrm{~mm}), 100$ : Coralliophila abbreviata $(25 \mathrm{~mm})$, 101: Corallioplita caribaea $(22 \mathrm{~mm})$ 


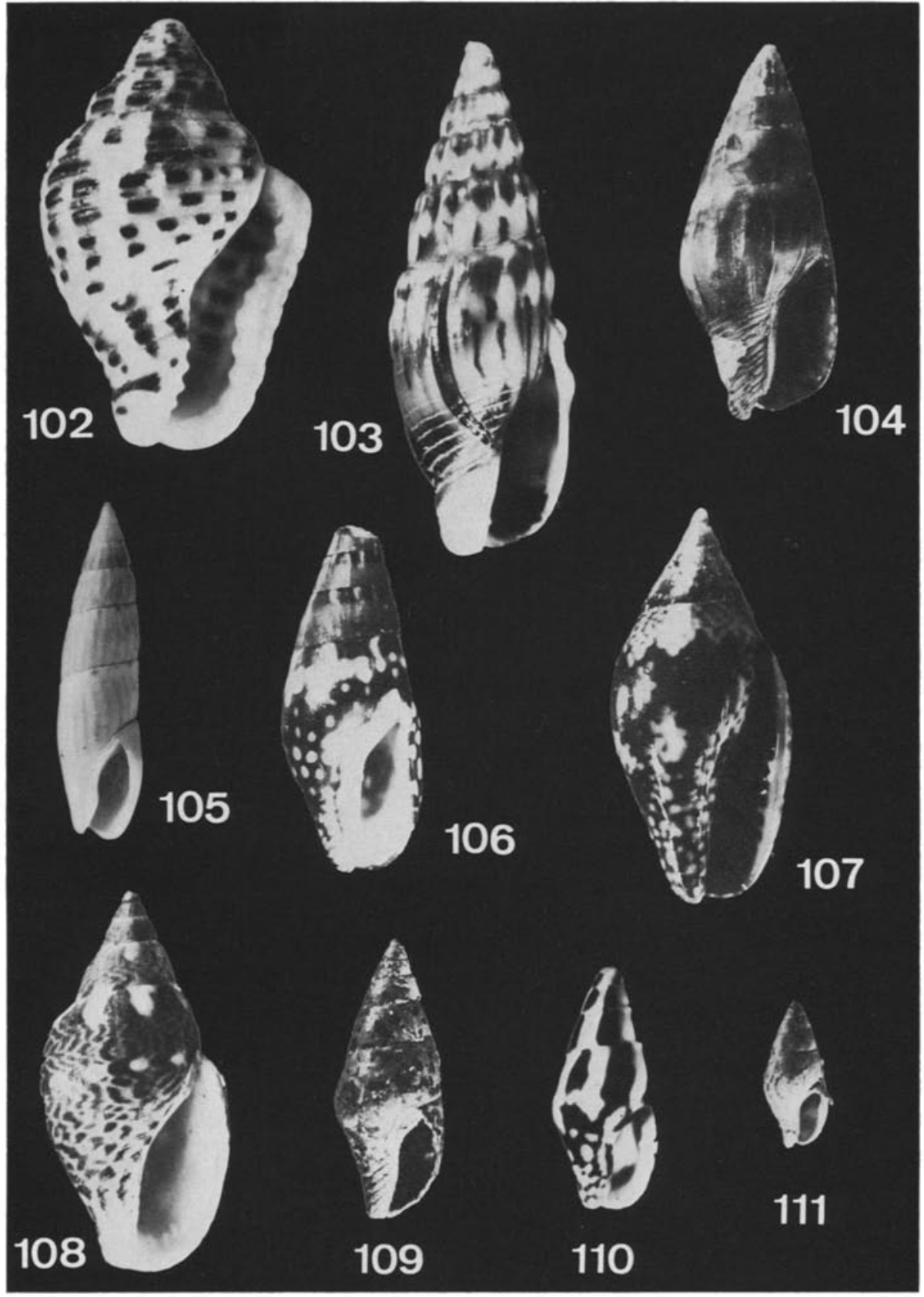

Abb. 102-111: Columbellidae. 102: Columbella mercatoria (14 mm hoch), 103: Mazatlania aciculata $(17 \mathrm{~mm}), 104$ : Anachis sparsa $(12 \mathrm{~mm}), 105:$ Aesopus metcalfei $(11 \mathrm{~mm}), 106:$ Nitidella ocellata (11 mm), 107: Nitidella nitida $(13 \mathrm{~mm}), 108$ : Nitidella laevigata $(12 \mathrm{~mm})$, 109: Mitrella ocellata $(7 \mathrm{~mm}), 110$ : Mitrella argus $(6,5 \mathrm{~mm}), 111:$ Mitrella lurata $(4 \mathrm{~mm})$ 
gezähnt. Oberfläche mit axialen Rippen und sehr feinen Spiralstreifen, die nur im unteren Teil der Endwindung deutlich sind. Grundfarbe gelblichbraun, mit dunkelbraunen Flecken. Fundort: Zwischen Punta de Granate und Punta Las Minas. Verbreitung: Westindien.

\section{Aesopus metcalfei ReEve 1859}

(Abb. 105)

Höhe $12 \mathrm{~mm}$, Breite $3 \mathrm{~mm}$. Gehäuse schlank spindelförmig, fest, unten breit abgestutzt. Umgänge kaum gewölbt. Mündung schmal, oben zugespitzt, unten mit kurzer, breiter Rinne. Oberfläche mit schmalen axialen Rippen. Hellgraubraun mit weißer Spirallinie unter der Naht und rotbraunen Flecken über der Naht. Fundorte: Bahía Concha, Ensenada Bonitogordo.

\section{Nitidella ocellata GMELIN 1791}

(Abb. 106)

Höhe $12 \mathrm{~mm}$, Breite $5 \mathrm{~mm}$. Gehäuse lang eiförmig. Apex spitz, aber meist korrodiert. Umgänge kaum gewölbt, Naht schwach ausgeprägt. Mündung hoch und schmal. Außenrand der Mündung innen gezähnt. Oberfläche mit schwacher axialer Streifung und deutlichen Spiralfurchen im unteren Teil der Endwindung. Mittel- bis dunkelbraun mit helleren Flecken und oft mit einem hellen Spiralband. Fundorte: Bahía Concha, Ensenada Bonitogordo, Isla de La Aguja, Ensenada de Granate, Punta de Betín, Morro de Gaira. Verbreitung: Lower Florida Keys, Bermudas, Westindien.

\section{Nitidella nitida LAMARCK 1822}

(Abb. 107)

Höhe $14 \mathrm{~mm}$, Breite $7 \mathrm{~mm}$. Gehäuse länglich eiförmig, Apex spitz. Umriß des Gewindes fast gerade, Naht schwach eingedrückt. Mündung schmal, Außenrand in der Mitte verdickt, innen gezähnt. Zwischen den Zähnen dunkel gefleckt. An der Spindelwand zwei niedrige Falten. Oberfläche glatt und glänzend. Farbe und Zeichnung sehr variabel: Grundfarbe gelb- oder hellbraun mit mittel- bis dunkelbraunen Flecken, die verschmelzen können. Fundorte: Ensenada Bonitogordo, Ensenada de Granate, Punta de Betín, Morro de Gaira. Verbreitung: Südöstliches Florida, Westindien.

\section{Nitidella laevigata LINNÉ 1758}

(Abb. 108)

Höhe $16 \mathrm{~mm}$, Breite $7,5 \mathrm{~mm}$. Gehäuseform wie bei $N$. nitida, Umgänge jedoch stärker gewölbt, Schale dünner. Mündung weiter, langgestreckt oval, Außenrand nicht verdickt, schwach gezähnt. Spiralstreifen im unteren Teil der Endwindung. Grundfarbe orange bis olivbraun mit weißen und dunkelbraunen Flecken und gewellten Bändern. Fundorte: Bahía Concha, Ensenada Bonitogordo, Ensenada de Granate, Punta de Betín, Morro de Gaira. Verbreitung: Florida Keys, Westindien.

\section{Mitrella ocellata GMELIN 1791}

(Abb. 109)

Höhe $7 \mathrm{~mm}$, Breite $3 \mathrm{~mm}$. Gehäuse länglich eiförmig mit spitzem Apex. Umgänge wenig gewölbt, durch schwach eingedrückte Nähte getrennt. Endwindung mit 
Spiralfurchen. Gehäuse hellbraun mit dunkelbraunen Flecken, die auf der Endwindung gitterartig verschmelzen. Fundort: Bahía Concha (lebend auf Braunalgen). Verbreitung: Südöstliches Florida, Bahamas, Mexiko, Westindien bis Brasilien, Pazifik (Baja California bis Ecuador).

\section{Mitrella argus ORBIGNY 1842}

(Abb. 110)

Höhe $6 \mathrm{~mm}$, Breite $3 \mathrm{~mm}$. Gehäuse länglich eiförmig mit gerundetem Apex. Endwindung mit Spiralfurchen. Mündung schmal, unten mit Rinne. Außenrand der Mündung innen gezähnt. Grundfarbe gelblichweiß, mit braunen axialen Bändern, die im unteren Teil der Endwindung netzartig verschmelzen. Fundort: Bahía Concha (lebend auf Braunalgen).

\section{Mitrella lunata SAY 1826}

(Abb. 111)

Höhe $4 \mathrm{~mm}$, Breite $1,5 \mathrm{~mm}$. Gehäuse länglich eiförmig mit spitzem Apex. 6-7 Umgänge mit deutlich eingetiefter Naht. Mündung schmal oval, Mündungswand außen leicht verdickt, innen mit 6-7 Zähnen. In der unteren Hälfte der Endwindung mit Spiralfurchen, sonst glatt. Auf gelblich-weißem Grund braune Zickzack-Bänder. Auf Braunalgen der Brandungszone. Fundort: Punta de Betín. Verbreitung: Massachusetts bis Florida, Texas, Westindien.

\section{Buccinidae}

\section{Engina turbinella KIENER 1836}

(Abb. 112)

Höhe $13 \mathrm{~mm}$, Breite 7,5 mm. Gehäuse eispindelförmig mit kegelförmigem Gewinde, dessen Seitenlinien fast gerade sind. Festschalig. Mündung schmal mit kaum abgesetztem Kanal. Außenrand verdickt, innen gezähnt. Spindel mit Falten. Spiralreifen mit axial untereinander angeordneten Knötchen. Dunkelbraun bis schwarz mit weißen Knötchen. Fundort: Bocachica. Verbreitung: Lower Florida Keys, Westindien.

\section{Pisania pusio LINNÉ 1758}

(Abb. 113)

Höhe $33 \mathrm{~mm}$, Breite $14 \mathrm{~mm}$. Gehäuse länglich eispindelförmig mit hohem Gewinde. Umgänge wenig gewölbt. Mündung schmal, oben zugespitzt, unten mit breitem, schwach gebogenem Kanal. Außenrand kaum verdickt, innen gezähnelt. Spindel mit einer Falte am Kanalbeginn sowie einer schwachen und einer krättigen parietalen Falte am oberen Mündungsrand. Feine, etwas knotige Spiralreifen, sehr feine axiale Streifen. Hell olivbraun mit weißen Spiralbändern und spiralig angeordneten rotbraunen Flecken. Fundorte: Bahía Concha, Punta de Betín, Ancon. Verbreitung: Südöstliches Florida, Westindien. 


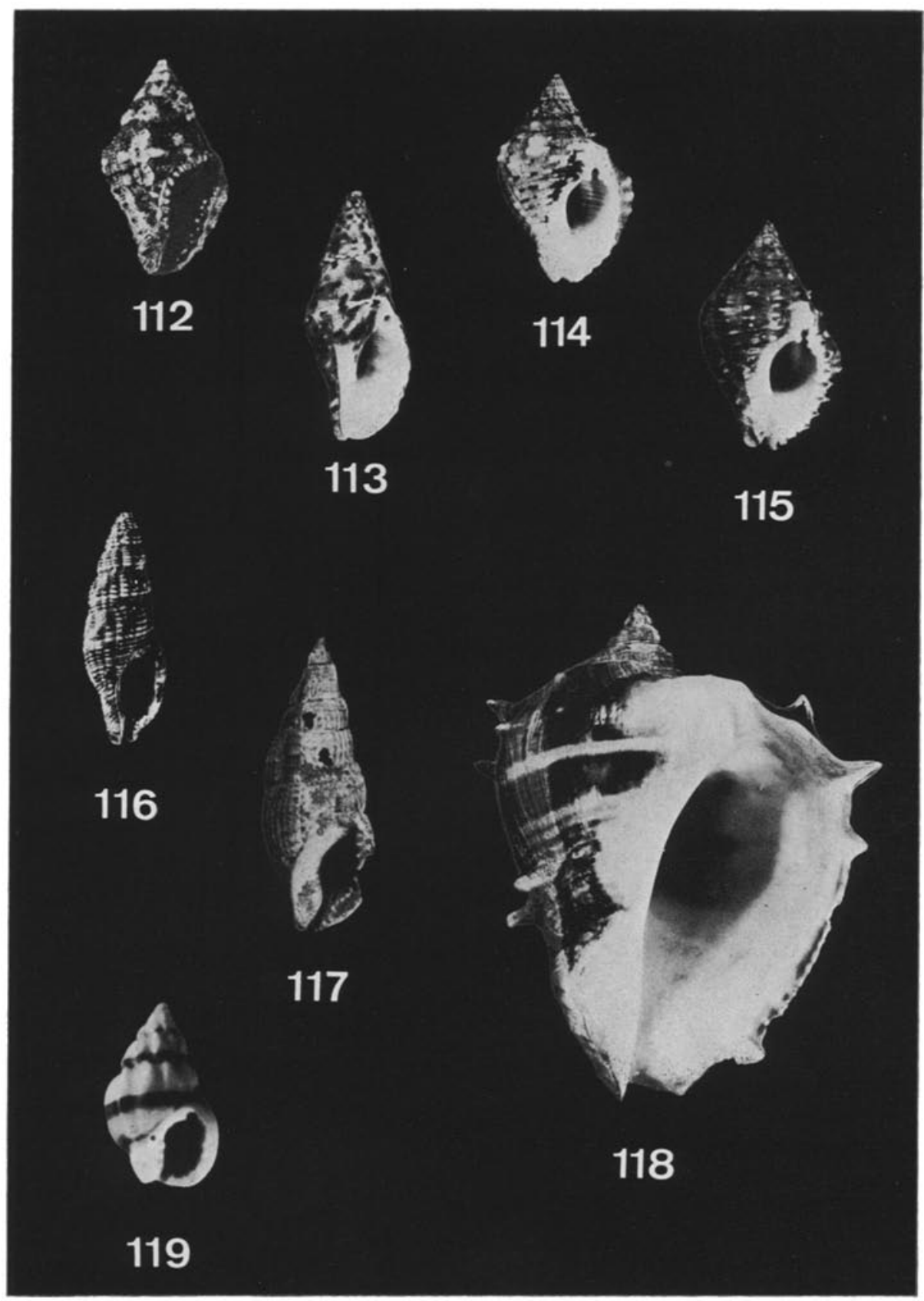

Abb. 112-119: Buccinidae, Melongenidae, Nassaridae. 112: Engina turbinella (13 $\mathrm{mm}$ hoch), 113: Pisania pusio $(33 \mathrm{~mm})$, 114: Cantbarus tinctus $(26 \mathrm{~mm}), 115$ : Cantharus auritulus $(29 \mathrm{~mm}), 116$ : Colubraria lanceolata $(14,5 \mathrm{~mm}), 117:$ Colubraria obscura $(38 \mathrm{~mm}), 118:$ Melongena melongena $(95 \mathrm{~mm}), 119:$ Nassarius albus $(8 \mathrm{~mm})$ 


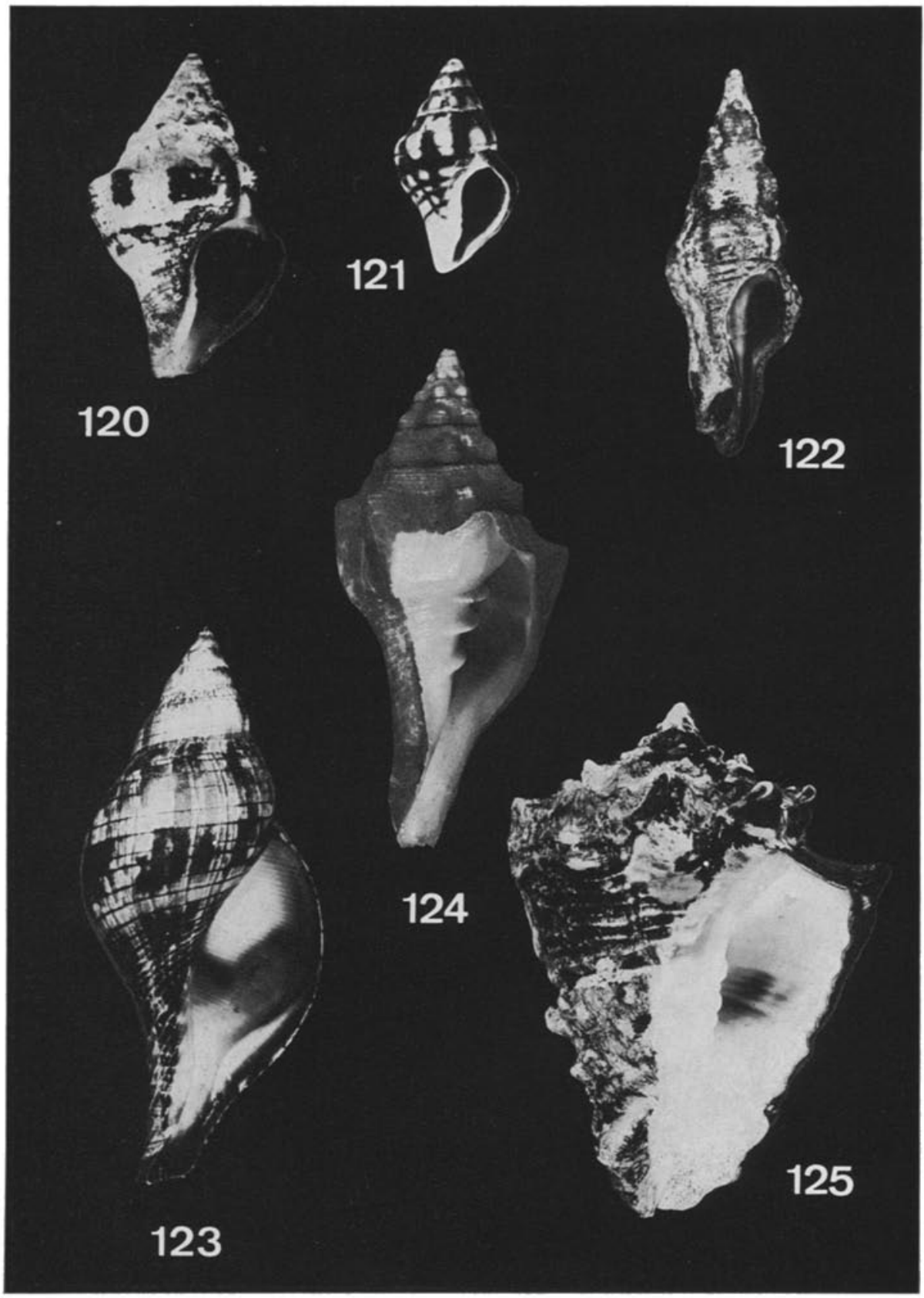

Abb. 120-125: Fasciolariidae, Xancidae. 120: Leucozonia nassa (21 mm hoch), 121: Leucozonia ocellata $(14,5 \mathrm{~mm}), 122$ : Latirus infundibulum $(66 \mathrm{~mm}), 123:$ Fasciolaria tulipa $(95 \mathrm{~mm})$, 124: Xancus angulatus $(140 \mathrm{~mm}), 125$ : Vasum muricatum $(88 \mathrm{~mm})$ 


\section{Cantharus tinctus CONRAD 1846}

(Abb. 114)

Höhe $26 \mathrm{~mm}$, Breite $17,6 \mathrm{~mm}$. Gehäuse bauchig spindelförmig, Gewinde kegelförmig. Umgänge unter der Naht konkay eingezogen. Mündung oval, oben und unten kanalartig ausgezogen. Außenrand verdickt, innen mit Spiralleisten, die am oberen Mündungsende besonders kräftig sind. Oberfläche mit Spiralreifen und zahlreichen feinen Spirallinien sowie axialen, knotentragenden Rippen. Hell- bis dunkelbraun mit weißen und dunkelbraunen Flecken. Fundorte: Ensenada de Granate, Punta de Betín, Morro de Gaira. Verbreitung: Südöstliche USA, Westindien.

\section{Cantharus auritulus LINK 1807}

(Abb. 115)

Höhe $34 \mathrm{~mm}$, Breite $20 \mathrm{~mm}$. Gehäuseform wie bei C. tinctus. Deutlich geschultert. Mit 9-11 ausgeprägten axialen Rippen auf der Endwindung und zahlreichen feinen Spiralstreifen. Hell- bis mittelbraun mit dunkelbraunen und weißen Flecken. Fundorte: Bahía Concha, Ensenada Bonitogordo, Isla de La Aguja, Ensenada de Granate, Punta de Betín, Bocagrande. Verbreitung: Südöstliches Florida, Westindien bis Brasilien.

\section{Colubraria lanceolata MENKE 1828}

(Abb. 116)

Höhe $15 \mathrm{~mm}$, Breite $5 \mathrm{~mm}$. Gehäuse schlank, getürmt. Umgänge gewölbt. Mündung schmal eiförmig, oben mit schmaler Bucht, unten mit kurzem Kanal. Axiale Rippen und schmalere Spiralstreifen gittern die Oberfläche. Hellbraun mit dunkelbraunen, spiralig und schräg verlaufenden Bändern. Fundorte: Ensenada de Granate, Punta de Betín. Verbreitung: Südöstliche USA, Westindien.

\section{Colubraria obscura ReEve 1844}

(Abb. 117)

Höhe $38 \mathrm{~mm}$, Breite $15 \mathrm{~mm}$. Gehäuse schlank, getürmt. Umgänge gewölbt, Naht deutlich. Apex meist korrodiert. Mündung zweieckig, oben gebuchtet, unten mit schmalem, zurückgebogenem Kanal. Außenrand verdickt, innen gezähnt. Kräftig ausgebildete Varizen, die auf dem Gewinde um etwa $240^{\circ}$ gegeneinander versetzt sind. Oberfläche mit gitterartig angeordneten Knoten. Hellbraun mit dunkelbraunen Flekken. Fundorte: Bahía Concha, Ancon. Verbreitung: Tortugas, Westindien.

\section{Melongenidae}

\section{Melongena melongena LINNÉ 1758}

(Abb. 118)

Höhe $110 \mathrm{~mm}$, Breite $79 \mathrm{~mm}$. Schale dick und schwer. Gewinde kurz und spitz, bei großen Schalen eingesunken. Naht deutlich, tief und breit kanalartig. $71 / 2$ gewölbte Umgänge. Nabel vom Parietalcallus bedeckt. Mündung subelliptisch, groß. Außen lippe in der unteren Hälfte kräftig gezähnt. Analkanal deutlich, Siphonalkanal kurz 
und weit. Columella dick, etwas gedreht und basal eine scharfe Kante gegen den Siphonalkanal bildend. Der glänzende Parietalcallus erstreckt sich etwa bis zur Mitte der Ventralseite des letzten Umganges. Skulptur der ersten Umgänge aus axialen Knoten und feinen Spirallinien. Auf den beiden letzten Umgängen mehrere spiralige Reihen großer, stumpfer Stacheln, auf dem letzten Umgang 2-3 Reihen auf der Schulter und 1 an der Basis. Daneben unregelmäßige Wachstumslinien. Schale cremefarben mit purpurbraunen Spiralbändern unterschiedlicher Breite. Parietalcallus und Mündung weiß. Um den Siphonalkanal und an der Mündungsbasis mit bräunlichem Anflug. Häufig im flachen Brackwasser der Ciénaga Grande de Santa Marta. Fundorte: Puebloviejo, Tolú. Verbreitung: Golfküste von Mexiko, Mittelamerika, Nordküste Südamerikas. In Westindien nur in Cuba, Isle of Pines, Hispaniola und Jamaica nachgewiesen.

\section{Nassariidae}

\section{Nassarius albus SAY 1826}

(Abb. 119)

Höhe $11 \mathrm{~mm}$, Breite 6,3 mm. Gehäuse eikegelförmig, Umgänge gewölbt. Endwindung groß, unten verschmälert und eingeschnürt. Mündung oval, oben gebuchtet, unten mit schmalem, tiefem Kanal. Außenrand der Mündung verdickt, innen gezähnt. Parietalrand mit 1 Zahn. Spindelschwiele gefältet. Etwa 11 axiale Rippen, dazwischen feine Spiralstreifen. Grundfarbe weiß bis gelbbraun, mit braunen Spiralbändern oder Flecken. Fundorte: Bahía Concha, Ensenada de Granate. Verbreitung: Südöstliche USA, Westindien.

\section{Fasciolariidae}

\section{Leucozonia nassa GMELIN 1791}

(Abb. 120)

Höhe $27 \mathrm{~mm}$, Breite $16 \mathrm{~mm}$. Gehäuse eispindelförmig, festschalig. Umgänge gewölbt, unter der Naht konkav eingezogen. Mündung oval, oben schmal ausgußförmig, unten mit Kanal, der etwa so lang wie die Mündung hoch ist. Spindel mit 3-4 Falten. Oberfläche mit Spiral- und schwächeren axialen Streifen sowie einer Spiralreihe großer Höcker. Mittelbraun. Häufig unter Steinen im flachen Wasser. Von Paguriden bewohnte Gehäuse häufig auf dem küstennahen Land. Fundorte: Ensenada Bonitogordo, Punta de Betín, Morro de Gaira. Verbreitung: Florida bis Texas, Westindien.

\section{Leucozonia ocellata GMELIN 1791}

(Abb. 121)

Höhe $15 \mathrm{~mm}$, Breite $8 \mathrm{~mm}$. Gehäuse eispindelförmig, festschalig. Umgänge gewölbt, unter der Naht etwas eingezogen. Mündung oval, obere Bucht schwach angedeutet, unterer Kanal schmal. Spindel mit drei kleinen Falten. Außenrand der Mündung innen mit schwachen Leisten. Hödker flach gerundet. Dunkelbraun, Höcker weiß. 
Im unteren Teil der Endwindung etwa 4 weiße Spiralbänder. Fundorte: Isla de La Aguja, Ensenada de Granate, Punta de Betín. Verbreitung: Florida, Westindien.

\section{Latirus infundibulum GMELIN 1791}

(Abb. 122)

Höhe $66 \mathrm{~mm}$, Breite $24 \mathrm{~mm}$. Gehäuse spindelförmig mit hohem Gewinde, festschalig. Umgänge gewölbt. Mündung oval, mit etwa ebensolangem, gebogenem Kanal. Außenrand der Mündung innen mit niedrigen Leisten. Spindel mit 3-4 Falten. Nabel offen, rinnenartig verlängert. Oberfläche mit Spiralreifen und 7-8 krältigen, stumpfen, axialen Rippen. Mittelbraun, mehr oder weniger stark überkrustet und bewachsen. Fundorte: Isla de La Aguja, Ensenada de Granate, Taganga, Bocachica. Verbreitung: Florida Keys, Westindien.

\section{Fasciolaria tulipa LiNnÉ 1758}

(Abb. 123)

Höhe $95 \mathrm{~mm}$, Breite $40 \mathrm{~mm}$. Gehäuse spindelförmig. Umgänge stark gewölbt, unter der Naht etwas eingezogen. Endwindung groß. Mündung lang, schmal eiförmig, oben mit ausgußartiger Bucht, unten mit Kanal, der etwa halb so lang wie die Mündung ist. Außenrand der Mündung scharf. Oberfläche mit schwachen axialen Streifen und etwa 3 Spiralreifen unter der Naht sowie Spiralreifen im unteren Teil der Endwindung. Mittelbraun mit dunkelbraunen Flecken und schmalen Spiralbändern. Fundorte: Cabo de La Vela, $8 \mathrm{~km}$ NE von Manaure, $2 \mathrm{~km}$ NE von Pájaro, Camarones, Buritaca, Bahía Concha, Ensenada de Granate, Taganga, Islas del Rosario. Verbreitung: Südöstliche USA, Westindien.

\section{Xancidae \\ Xancus angulatus SOLANDER 1786 \\ (Abb. 124)}

Höhe $360 \mathrm{~mm}$, Breite $180 \mathrm{~mm}$. Schale stark, sehr schwer. Gehäuse fusiform. Gewinde hoch. Naht mäßig kanaliert. 9-11 Umgänge. Nabel tief, bei extrem großen Exemplaren weit offen, bei kleineren bis auf einen Schlitz vom Parietalcallus bedeckt. Mündung groß, länglich. Außenlippe scharf, innen mit einem besonders bei jüngeren Exemplaren deutlichen, nach innen ziehenden Wulst. Columella gekurvt mit 3 starken, einwärtslaufenden Falten im Mittelteil. Parietalcallus und Außenlippe zu einem langen und breiten Siphonalkanal ausgezogen. Skulptur aus stumpfen Axialwülsten, auf der Schulter nach oben weisende Knoten bildend. Zwischen Naht und Schulterknoten und auf der Basis zahlreiche feine Spiralleisten, gekreuzt von dicht liegenden. Wachstumslinien. Schale gelb-weiß, von einem krättigen, hell- bis dunkelbraunen Periostracum bedeckt, das bei Juvenilen fein behaart ist. Mündung weiß, Parietalcallus glänzend lachsfarben. Im Flachwasserbereich; nicht sehr häufig. Fundorte: Bahía Concha, Isla de La Aguja, Punta de Betín, Ancon. Verbreitung: Bahamas, Florida Keys, Cuba, Mittelamerika von Yucatan südwärts, Kolumbien. 


\section{Vasum muricatum BORN 1778}

(Abb. 125)

Höhe $108 \mathrm{~mm}$, Breite $92 \mathrm{~mm}$ (mit Stacheln). Schale dick und schwer. Gewinde flach-konisch, Apex spitz. Naht deutlich, undulierend. 8-9 geschulterte Umgänge. Mündung lang, relativ schmal im basalen Drittel. Siphonalkanal kurz und nach dorsal gekurvt. Außenlippe scharf und wellig. Columella dick, mit 5 kräftigen Falten im Mittelteil. Skulptur aus 8-10 starken, konischen Stacheln auf der Schulter und 2-3 spiraligen Stachelreihen an der Basis, die Stacheln der obersten länger als die übrigen. An der Basis 1-2 schräg abwärtsziehende Wülste. Außer Stacheln und Wülsten zahlreiche feine Spiralleisten und Wachstumslinien auf den Umgängen. Periostracum dickpelzig, olivbraun. Schale kalkweiß. Mündung weiß oder blauweiß, Außenlippe und Rand des Parietalcallus bräunlich getönt. Operculum nicht verkalkt, dick, klauenförmig, mit randlichem Wulst auf Innenseite. Im Flachwasserbereich zwischen Steinen und Korallenblöcken. Fundorte 8-10 km NE von Manaure, Ensenada Bonitogordo, Bunta de Betín, Bocachica, Isla Barú. Verbreitung: Südflorida, Westindien.

\section{Olividae \\ Oliva reticularis LAMARCK 1811 \\ (Abb. 126)}

Höhe $51 \mathrm{~mm}$, Breite $24 \mathrm{~mm}$. Gehäuse mehr oder weniger zylindrisch. Gewinde niedrig und konisch. Apex spitz. Naht rinnenförmig. $6^{1 / 2}$ gerade Umgänge, der letzte mäßig konvex. Ungenabelt. Mündung eng, etwa $4 / 5$ der Höhe. Außenlippe dick. Columella im basalen Drittel nach links gekurvt. Mündung nicht gegen Siphonalkanal abgesetzt. Columella mit zahlreichen, zur Basis stärker werdenden Spiralleisten. Schale glatt und glänzend, nur an der Basis eine schräg abwärts ziehende Falte. Grundfarbe gelblich, überlagert von einem grauen und purpurbraunen netzartigen Muster. Apex und die ersten 1/2 Umgänge hornfarben. Mündungsrand blauweiß, mit dunklen Flecken auf der Innenseite der Außenlippe. Fundorte: Cabo de La Vela, $2 \mathrm{~km}$ NE von Pájaro, Bahía Concha, Ensenada Bonitogordo, Ensenada de Granate, Taganga. Verbreitung: Südöstliches Florida, Westindien.

\section{Oliva caribaeensis DaLl \& Simpson 1901}

(Abb. 127)

Höhe $43 \mathrm{~mm}$, Breite $19 \mathrm{~mm}$. Gehäuse zylindrisch. Gewinde sehr niedrig, konisch. Apex spitz. Naht tief und breit kanaliert. 7-71/2 Umgänge, der letzte weniger konvex als bei $O$. reticularis. Ungenabelt. Mündung sehr eng. Außenlippe kräftig verdickt. Columella mit zahlreichen, zur Basis hin etwas kräftiger werdenden Leisten. Schale glatt und glänzend, nur an der Basis eine schräg abwärts ziehende Falte. Grundfarbe gelblich bis hellbraun, mit dunkler braunen, unregelmäßigen Linien, die auf dem letzten Umgang deutlich 2 Spiralbänder bilden. Mündung bläulich-weiß. Fundort: Bahía Concha. Verbreitung: Karibisches Meer. 


\section{Olivella nivea GMELIN 1791}

(Abb. 128)

Höhe $19 \mathrm{~mm}$, Breite $7 \mathrm{~mm}$. Gehäuse spindelförmig. Apex scharf. Naht schlitzförmig. 6-7 leicht konvexe Umgänge. Mündung etwa dreieckig und halb so hoch wie das Gehäuse. Columella in sich gedreht, mit Spiralfalten. Parietalcallus wulstartig, bis zur Schulter des vorletzten Umganges reichend. Schale glatt und glänzend, weiß bis hellgelb, mit je einem Band hell purpurbrauner Flecken unter der Naht und an der Basis. Zwischen beiden Bändern die Grundfarbe des letzten Umganges von schwachem. Gelbbraun überlagert. Fundort: Bahía Concha. Verbreitung: Bermudas, südöstliches Florida, Bahamas, Westindien.

\section{Olivella minuta LiNK 1807}

(Abb. 129)

Höhe $12,5 \mathrm{~mm}$, Breite $6,5 \mathrm{~mm}$. Gehäuse aufgetrieben spindelförmig. Gewinde etwas kürzer als die Mündung. Apex stumpf. Naht linienförmig eingeschnitten. Mündung eng, Außenlippe stark verdickt. Columella dick, im basalen Drittel mit einem vorspringenden Zahn. Am oberen Ende des Columellarcallus ein feines Zähnchen, zwischen beiden eine Reihe undeutlicher Zähnchen. Parietalcallus wulstartig, bis zur Schulter des vorletzten Umganges reichend. Schale glatt, weißgrau, mit dunkelbraunen, wellenförmigen Axiallinien. Unter der Naht und an der Basis je eine dunkelbraune Spirallinie. Fundort: Bahía Concha. Verbreitung: Westindien.

\section{Mitridae}

\section{Pusia puella ReEve 1845}

(Abb. 130)

Höhe $10 \mathrm{~mm}$, Breite $5 \mathrm{~mm}$. Gehäuse gedrungen spindelförmig. Apex spitz. Größte Gehäusebreite an der leichten Schulter der Endwindung. Naht wenig eingetieft. Oberfläche durch Axial- und weniger ausgeprägte Spiralfurchen gegittert. Mündung schmal, mit 4 Columellarfalten, von denen die beiden apicalen am kräftigsten sind. Grundfarbe hellgrau mit brauner und bleigrauer Flammenzeichnung. Fundort: Bahía Concha. Verbreitung: Südöstliche USA, Kleine Antillen.

\section{Pusia cubana AcNayo \& Rehder 1936}

(Abb. 131)

Höhe $11 \mathrm{~mm}$, Breite $5 \mathrm{~mm}$. Gehäuse schlanker als das von $P$. puella. Naht deutlich eingetieft. Umgänge nicht geschultert. Oberfläche mit Axialrippen (12 auf der Endwindung) und Spiralstreifen. Mündung schmal, schräggestellt, mit 4 Columellarfalten, von denen die apicale die kräftigste ist. Gehäuse weiß, mit braunem Spiralband in der unteren Hälfte der Endwindung und kleinen rotbraunen Flecken zwischen den Axialrippen. Fundort: Bahía Concha. Verbreitung: Nordküste Kubas, Grand Cayman Island. 
Volutidae

Voluta musica LinNé 1758

(Abb. 132)

Höhe $54 \mathrm{~mm}$, Breite $29 \mathrm{~mm}$. Schale dick und schwer. Gewinde konisch. Naht deutlich, aber nicht vertieft, undulierend. 61/2 leicht konvexe Ungänge; die 3 Embryonalumgänge aufgetrieben. Ungenabelt. Mündung länglich, an der Basis etwas verbreitert. Außenlippe bis auf das obere Viertel stark verdickt. Innenlippe mit etwa 11 einwärtslaufenden Leisten, die unteren 5 dick, die oberen weniger prominent. Siphonalkanal kurz, weit und nach dorsal gekurvt. Skulptur aus stumpfen, dicken Knoten auf der Schulter, die sich nach unten in flacher werdende Axialrippen fortsetzen. An der Basis schräg abwärtsziehende Furche und Leiste. Feine axiale Wachstumslinien. Schale elfenbeinfarben bis graubraun, mit breitem Band purpurbrauner, auf die Außenlippe übergreifender Flecken (die „Noten") auf der Schulter und unterhalb der Mitte des letzten Umganges. Dazwischen feine braune Spirallinien (die "Notenlinien“). Relativ selten. Fundorte: Cabo de La Vela, Media Luna. Verbreitung: Karibisches Meer.

\section{Voluta virescens SOLANDER 1786}

(Abb. 133)

Höhe $46 \mathrm{~mm}$, Breite 24,5 mm. Schale dick, aber nicht schwer; Gewinde spitzkonisch. Naht undulierend. 7 Umgänge, durch Knoten deutlich geschultert. Ungenabelt. Mündung lang und schmal. Außenlippe bis auf das obere Viertel stark verdickt. Parietalcallus mit 9-12 unterschiedlich starken Spiralleisten. Siphonalkanal kurz, weit und nach dorsal gekurvt. Skulptur aus 8-10 scharfen Knoten auf der Schulter, die nach unten in flacher werdende Axialrippen auslaufen. Außerdem feine Spirallinien und an der Basis deutliche Wachstumslinien. Embryonalschale weiß und glatt. Restliche Schale elfenbeinfarben, mit grau- bis purpurbraunen Spiralbändern. Auf der Außenlippe 6 oder mehr dunkelbraune Flecken. Am Rand des Parietalcallus ein schwarzbraunes Band. Fundort: Tolú. Verbreitung: Von Nicaragua bis Kolumbien.

\section{Cancellariidae}

\section{Cancellaria reticulata LINNÉ 1767}

(Abb. 134)

Höhe $28 \mathrm{~mm}$, Breite $18 \mathrm{~mm}$. Gehäuse eikegelförmig. Umgänge gewölbt, deutlich voneinander abgesetzt. Endwindung groß, bedeckt genabelt, mir kräftigem Siphonalwulst. Mündung oval. Zwei große Falten auf der Spindelwand. Oberfläche gegittert. Gehäuse hellbraun mit weißen und dunkelbraunen Bändern und Flecken. Fundort: Buritaca. Verbreitung: Südöstliche USA, Westindien.

$$
\text { Marginellidae }
$$

\section{Persicula interruptelineata MüHLFELD 1818}

(Abb. 135)

Höhe $14 \mathrm{~mm}$, Breite $9 \mathrm{~mm}$. Gehäuse eispindelförmig, Cypraea-ähnlich. Gewinde nicht erhoben, von der Endwindung weitgehend umschlossen. Nähte durch Schmelz- 


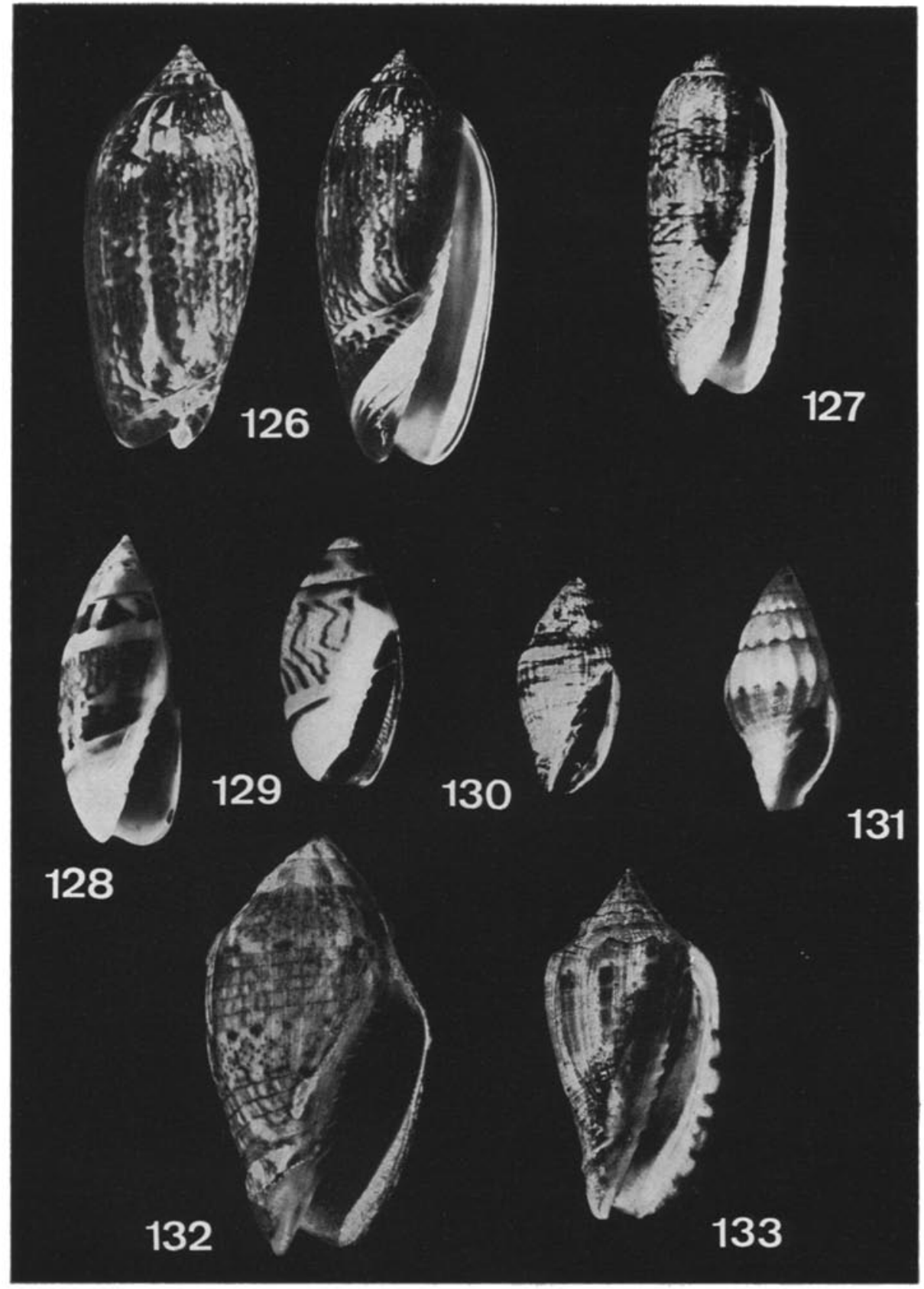

Abb. 126-133: Olividae, Volutidae. 126: Oliva reticularis (53 mm), 127: Oliva caribaensis $(43 \mathrm{~mm}), 128$ : Olivella nivea $(12 \mathrm{~mm}), 129$ : Olivella minuta $(10,5 \mathrm{~mm}), 130$ : Pusia puella $(9,5 \mathrm{~mm}), 131$ : Pusia cubana $(11 \mathrm{~mm}), 132$ : Voluta musica $(53,5 \mathrm{~mm}), 133$ : Voluta virescens $(46 \mathrm{~mm})$ 


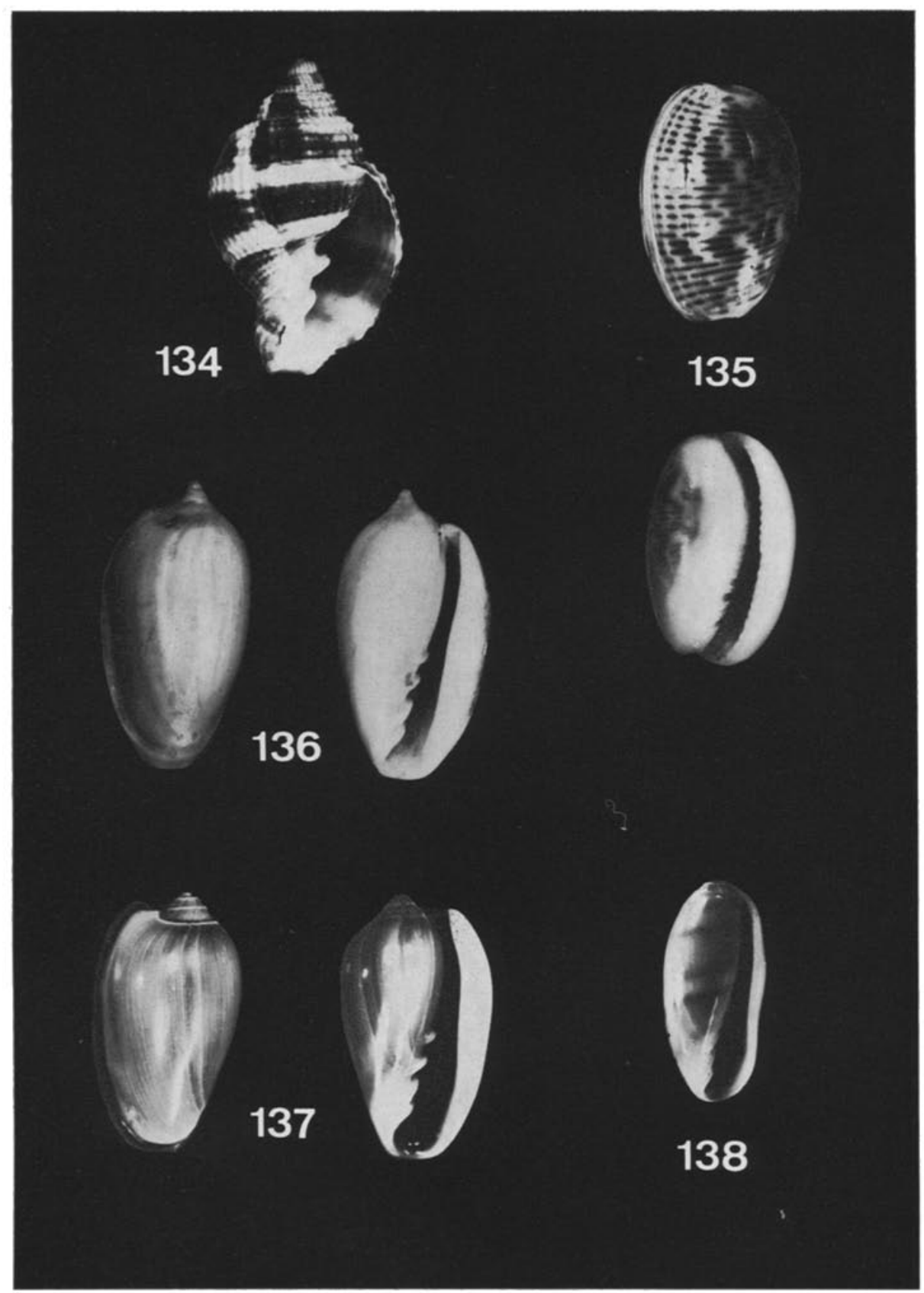

Abb. 134-138: Cancellariidae, Marginellidae. 134: Cancellaria reticulata (27 $\mathrm{mm}$ hoch), 135: Persicula interruptelineata $(10 \mathrm{~mm}), 136:$ Prunum marginatum $(25,7 \mathrm{~mm}), 137$ : Prunum prunum (24 mim), 138: Hyalina avena (7 mm) 
schicht ausgefüllt. Mündung hoch und schmal, Außenrand verdickt, innen schwach gezähnelt. Spindel mit Falten, von denen die zweitunterste wulstig verdickt und nach innen längsgespalten ist. Oberfläche glatt und glänzend. Grundfarbe gelblichweiß, mit rotbraunen Stricheln in Spiralrichtung und Flecken am Apex. Fundorte: Buritaca, Bahía Concha, Punta La Loma. Verbreitung: Puerto Rico, Guayana.

\section{Prunum marginatum BoRN 1778}

(Abb. 136)

Höhe $26 \mathrm{~mm}$, Breite $14 \mathrm{~mm}$. Gehäuse eispindelförmig, Gewinde niedrig kegelförmig. Endwindung dominiert. Mündung hoch und schmal, unten abgestutzt, Außenrand verdickt, innen glatt. Spindel mit 4 kräftigen Falten, von denen die beiden unteren einander genähert sind. Gehäuse hellbraun, manchmal mit dunklerer Strichelung. Fundorte: Ensenada de Granate, Taganga. Verbreitung: Karibische See.

\section{Prunum prunum GMELIN 1791}

(Abb. 137)

Höhe $32 \mathrm{~mm}$, Breite $18 \mathrm{~mm}$. Gehäuseform wie bei $P$. marginatum. Außenrand der Mündung oben flügelartig hochgezogen. Oberfläche glatt, glänzend. Apex, Nähte und Außenrand der Mündung braun, Oberfläche oliv, mit feinen weißen und braunen Axialstreifen. Fundorte: $8 \mathrm{~km}$ NE von Manaure, $2 \mathrm{~km}$ NE von Pájaro, Buritaca, Isla de Salamanca, Golfo de Morrosquillo. Verbreitung: Panama.

\section{Hyalina avena KIENER 1834}

(Abb. 138)

Höhe $7 \mathrm{~mm}$, Breite $3 \mathrm{~mm}$. Gehäuse zylindrisch-oval. Gewinde kaum erhoben. Endwindung sehr groß. Mündung hoch und schmal, unten erweitert. Außenrand der Mündung etwas verdickt, besonders in der Mitte. Spindel mit 4 Falten. Oberfläche glatt, glänzend. Cremefarben mit 4-6 dunkleren Spiralstreifen. Fundort: Ensenada Bonitogordo. Verbreitung: Südöstliche USA, Westindien.

\section{Conidae}

\section{Conus regius GMELIN 1791}

(Abb. 139)

Höhe $43 \mathrm{~mm}$, Breite $25 \mathrm{~mm}$. Gewinde niedrig, gerade, winklig in den letzten Umgang ïbergehend. Naht undeutlich. Mündung schmal, an der Basis sich etwas erweiternd. Außenlippe scharf, leicht gezähnt, oberhalb der Schulter kurvig zurückgezogen. Auf der Schulter 13-15 knotenartige Höcker. Oberhalb der Höcker und auf der Oberfläche des letzten Umganges zahlreiche feine, mit Körnchen besetzte Spirallinien. Färbung sehr variabel, gelb- bis rotbraun mit unregelmäßigen weißen Flecken. Innenrand der Außenlippe mit unregelmäßig angeordneten, schokoladebraunen Flekken. Gewinde häufig mit Kalkalgen-Krusten bedeckt. Fundorte: Isla de La Aguja, Ensenada de Granate. Verbreitung: Südflorida, Bahamas, Westindien. 


\section{Conus mus Hwass 1792}

(Abb. 140)

Höhe $27 \mathrm{~mm}$, Breite $17 \mathrm{~mm}$. Gewinde flach-konisch, konkav. Apex spitz. Mündung sehr eng. Außenlippe scharf und fein gezähnt. Auf der Schulter flache, langgestreckte Knoten. Feine Spirallinien besonders oberhalb der Schulter und an der Basis. Periostracum relativ dick, olivgrün. Schale blaugrau mit olivbraunen oder braunen Flecken. Etwas unterhalb der Mitte des letzten Umganges ein helles Band. Knoten weiß, zwischen ihnen braune Flecken. Außenlippe blauweiß, auf Innenseite schokoladebraun mit hellem Band nahe der Mitte. Ziemlich häufig in Korallenriffen. Fundorte: Bahía Concha, Ensenada de Granate, Punta de Betín, Bocachica. Verbreitung: Südöstliches Florida, Westindien.

\section{Conus jaspideus GMeLIN 1791}

(Abb. 141)

Höhe $17 \mathrm{~mm}$, Breite $10 \mathrm{~mm}$. Gewinde mäßig erhoben, leicht konkav. Schulter ohne Knoten. Auf der unteren Hälfte des letzten Umganges 7-11 flache, von scharf inzisierten Linien getrennte Spiralleistchen. Schale graublau mit braunen Flecken, bei einigen Exemplaren als unregelmäßige axiale Bänder, bei anderen unregelmäßig verteilt. Letzter Umgang mit zahlreichen Spiralreihen kleiner brauner Pünktchen. Fundorte: Bahía Concha, Ensenada de Granate. Verbreitung: Südliches Florida, Westindien, Mexiko bis Venezuela.

\section{Conus spurius GMELIN 1791}

(Abb. 142)

Höhe $49 \mathrm{~mm}$, Breite $31 \mathrm{~mm}$. Schale dick und schwer. Gewinde mäßig erhoben, konkav. Die ersten Umgänge leicht aufgetrieben. Mündung schmal. An der Basis der Innenlippe ein kurzer Columellarcallus. Schulter ohne Knoten, nur mit feinen kurvigen Wachstumslinien. An der Basis feine Spirallinien. Schale weiß mit rotbraunen Flecken unterschiedlicher Ausdehnung, die spiralig und axial angeordnet sind. Fundort: $8-10 \mathrm{~km}$ NE von Manaure. Verbreitung: Bahamas, Große Antillen.

\section{Conus aurantius Hwass 1792}

(Abb. 143)

Höhe $29 \mathrm{~mm}$, Breite 17,5 mm. Gewinde mäßig erhoben, schwach konkav. Auf der Schulter eine Reihe gerundeter Knoten. Im basalen Teil des letzten Umganges leicht geknotete Spiralleisten. Schale weiß mit großen, unregelmäßigen braunen Flekken. Fundorte: Ensenada Bonitogordo, Ensenada de Granate. Verbreitung: Einzelnachweise von Bonaire und Curaçao.

\section{Terebridae}

\section{Terebra taurinus Solander 1786}

(Abb. 144)

Höhe $91 \mathrm{~mm}$, Breite $18 \mathrm{~mm}$. Gehäuse turmförmig, schlank. Gewinde sehr hoch. Nähte deutlich eingetieft. Endwindung klein, mit kurzem Spindelfortsatz, der am 


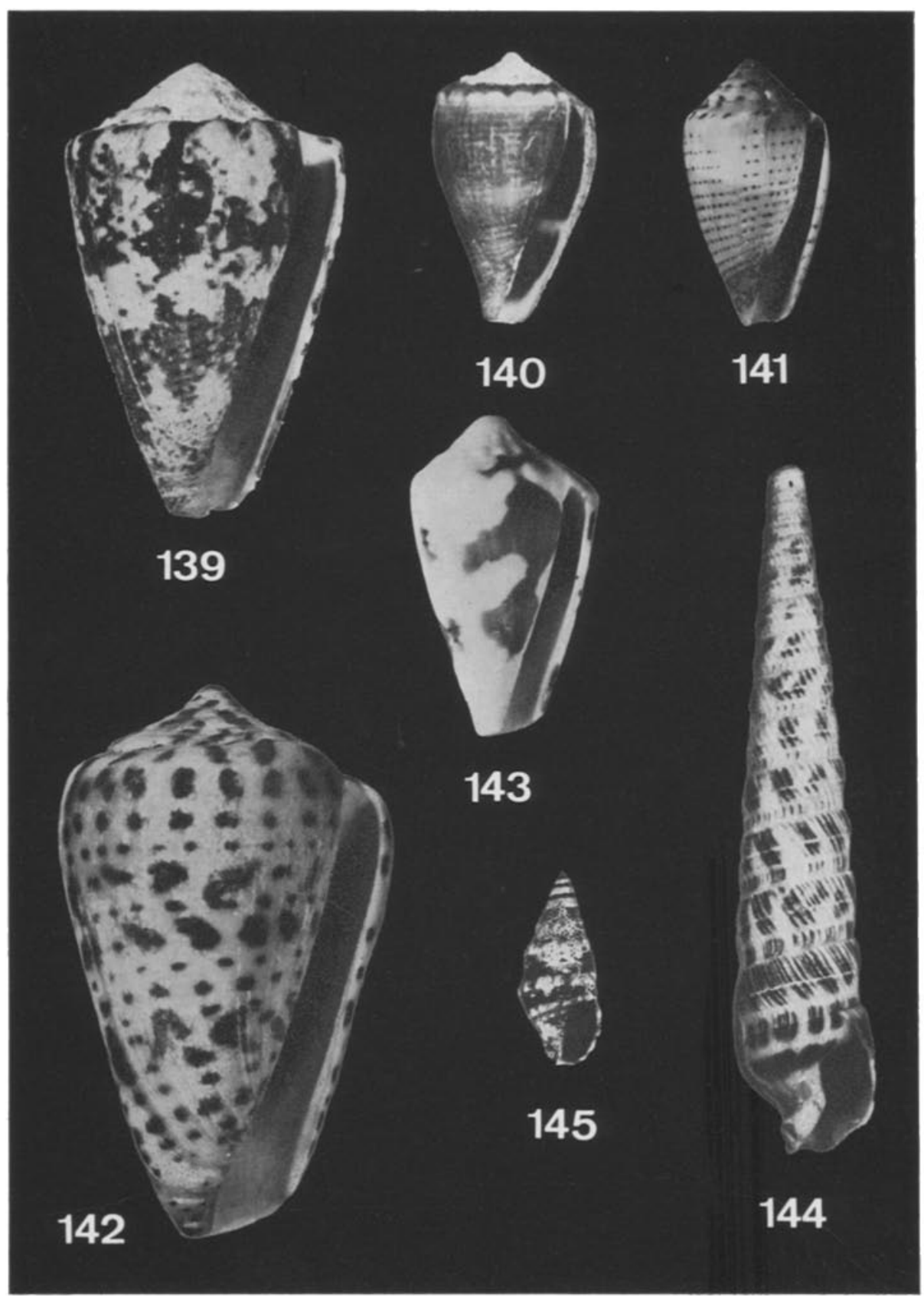

Abb. 139-145: Conidae, Terebridae, Turridae. 139: Conus regius ( $39 \mathrm{~mm}$ hoch), 140: Conus mus $(18 \mathrm{~mm}), 141$ : Conus jaspideus $(17 \mathrm{~mm}), 142$ : Conus spurius $(47 \mathrm{~mm}), 143$ : Conus aurantius $(20 \mathrm{~mm}), 144:$ Terebra taurinus $(91 \mathrm{~mm}), 145:$ Crassispira albomaculata $(12 \mathrm{~mm})$ 
Grunde einen spiraligen Wulst trägt. Mündung gerundet viereckig, unten mit kurzem, schrägem Kanal. Die oberen zwei Drittel der Umgänge sind durch eine Spiralfurche deutlich vom unteren Drittel getrennt. Der obere Teil ist gewölbter und durch eine weitere Spiralfurche unterteilt. Oberfläche schräg axial gerippt. Cremefarben mit rotbraunen, axialen Flammenzeichnungen. Fundort: Bahía Concha. Verbreitung: Südöstliches Florida, Golf von Mexiko, Westindien.

\section{Turridae}

\section{Crassispira albomaculata ORBIGNY 1842}

(Abb. 145)

Höhe $12 \mathrm{~mm}$, Breite $5 \mathrm{~mm}$. Gehäuse turmförmig. Naht wenig eingetieft. Endwindung wenig größer als die vorhergehende. Mündung schmal, schräggestellt, unten mit kurzem Kanal. Oberfläche mit Spiralreihen von Knoten, die mittlere Reihe auf jedem Umgang dominierend. Grundfarbe oliv- bis schwärzlichbraun. Knoten der Mittelreihe weiß. Fundort: Punta de Betín. Verbreitung: Westindien.

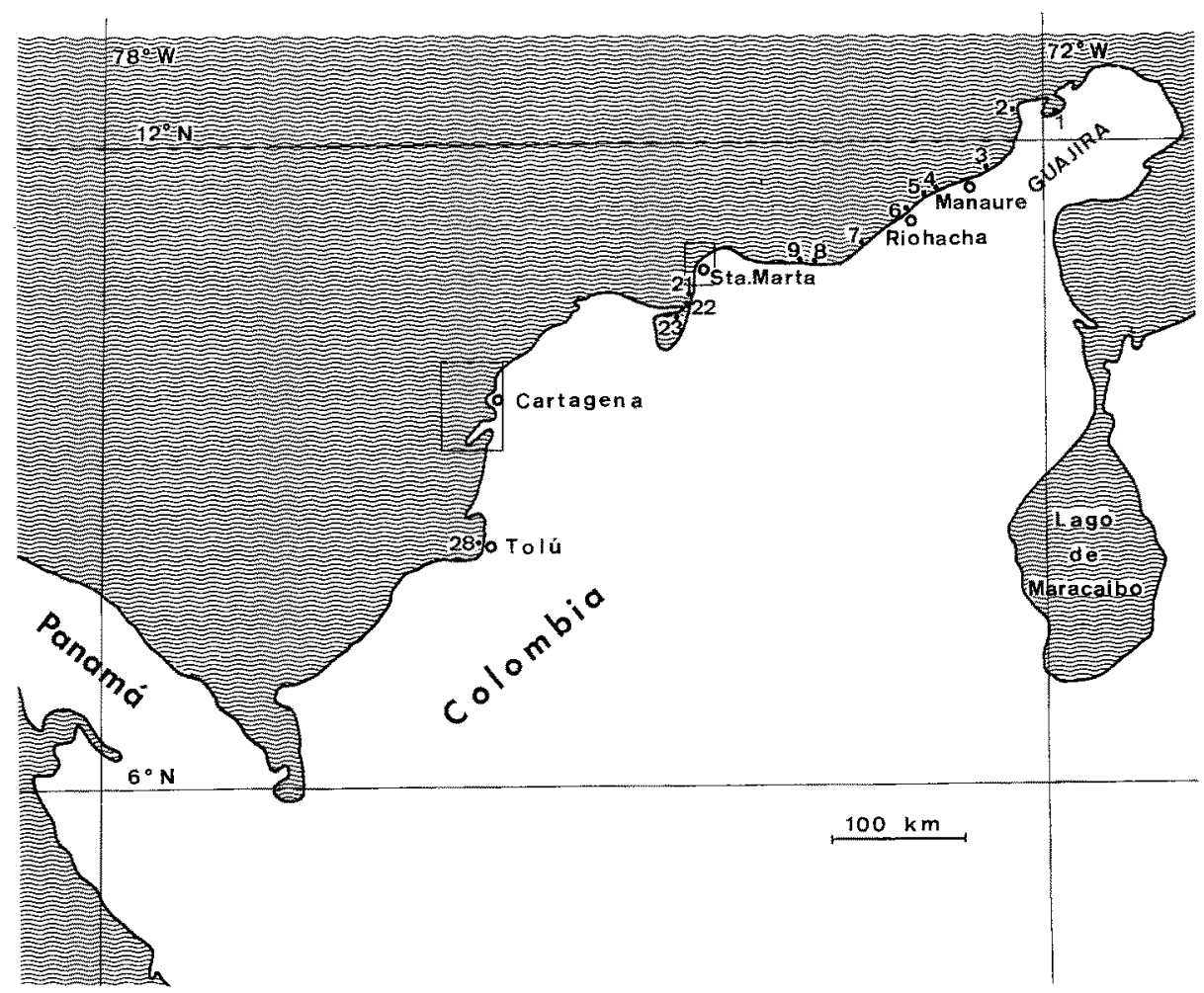

Abb. 146: Kartenskizze der kolumbianischen Atlantikküste. 1 Media Luna, 2 Cabo de La Vela, $38 \mathrm{~km}$ nordöstlich von Manaure, $42 \mathrm{~km}$ nordöstlich von Pájaro, 5 Pájaro, 6 Riohacha, 7 Camarones, 8 Don Diego, 9 Buritaca, 21 Punta de Papare, 22 Puebloviejo, 23 Mündung der Ciénaga Grande de Santa Marta, 28 Tolú / Golfo de Morrosquillo 


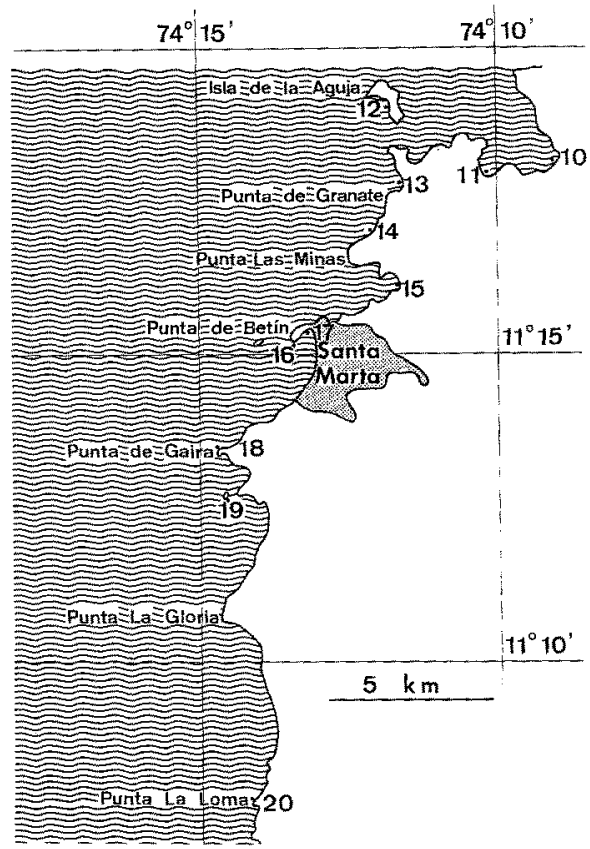

Abb. 147

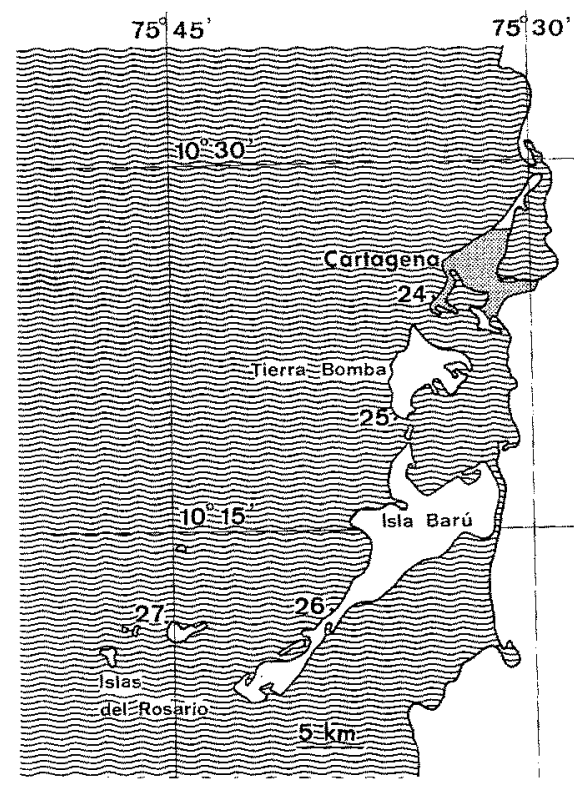

Abb. 148

Abb. 147: Kartenskizze dex Fundorte in der näheren Umgebung von Santa Marta. 10 Bahía Concha, 11 Ensenada Bonitogordo, 12 Isla de La Aguja, 13 Ensenada de Granate, 14 zwischen Punta de Granate und Punta Las Minas, 15 Taganga, 16 Punta de Betín, 17 Ancon, 18 Punta de Gaira, 19 Morro de Gaira, 20 Punta La Loma

Abb. 148: Kartenskizze der Fundorte in der näheren Umgebung von Cartagena. 24 Bocagrande, 25 Bocachica, 26 Isla Barú, 27 Islas del Rosario

\section{ZUSAMMENFASSUNG}

1. Im Litoral der karibischen Küste Kolumbiens wurden 145 ProsobranchierArten nachgewiesen, die 79 Gattungen und 44 Familien zugehören. Die Arten werden beschrieben und abgebildet.

2. Die Aufsammlungen wurden vor allem an den Küstenstreifen von Santa Marta, Cartagena und der Halbinsel Guajira gemacht. Dabei wurden die Biotope Felslitoral, Korallenriff, Sandstrand und Brackwasserlagune erfaßt.

Danksagungen. Wir danken Herrn R. T. Aввотт, Ph.D., Delaware Museum of Natural History, für die Bestimmung und Überprüfung einiger Arten sowie dem Tropeninstitut der Justus-Liebig-Universität Gießen, das einem der Autoren (Görring) durch finanzielle Unterstützung einen längeren Studienaufenthalt in Santa Marta ermöglichte. 


\section{ZITTERTE LITERATUR}

Arnow, L., Clair, F. S. \& Arnow, T., 1963. The Mollusca of a lagoonal area at Playa de Vega Baja, Puerto Rico. Caribb. J. Sci. 3, 163-172.

Bakus, G. J., 1968. Zonation in marine gastropods of Costa Rica and species diversity. Veliger 10, 207-211.

Benthem Jutting, T. van, 1927. Marine Mollusca of the Island of Curaçao. Bijdr. Dierk. 25, $1-36$.

Coomans, H. E., 1958. A survey of the littoral Gastropoda of the Netherlands Antilles and other Caribbean islands. Stud. Fauna Curaçao 8, 42-111.

Flores, C., 1968. Algunos gastropodos de las Islas Las Aves, Venezuela, y su distribución. Bol. Inst. Oceanogr. Univ. Oriente 7, 73-106.

Jaume, M. L., 1946. Moluscos marinos litorales del Cábo Catoche, Yucatan, Mexico. - Revta Soc. malac. Carlos de la Torre 4, 95-110.

Jong, K. M. De \& KRISTEnsen, L., 1965. Gegevens over mariene gastropoden van Curaçao. KorrespB1. ned. malac. Veren. (Suppl. Bd) 65, 1-56.

LEwIS, J. B., 1960. The fauna of rocky shores of Barbados, West Indies. Can. J. Zool. 38, $391-435$.

Olsson, A. A. \& McGrnty, T. L., 1958. Recent marine molluscs from the Caribbean coast of Panama with the description of some new genera and species. Bull. Am. Paleont. 39, 1-58.

Rodríguez, G., 1959. The marine communities of Margarita Island, Venezuela. Bull. mar. Sci, Gulf Caribb. 9, 237-280.

WarmKe, G. L. \& Aвbott, R. T., 1962. Caribbean Seashells. Livingston, Narberth, Penn., 348 pp.

Work, R. C., 1969. Systematics, ecology and distribution of the molluscs of Los Roques, Venezuela. Bull. mar. Sci. 19, 614-711.

Anschrift des erstgenannten Autors: Dr. R. KaufmanN

Instituto Colombo-Alemán

Apartado Aéreo 1016

Santa Marta/Magd.

Colombia, S.A. 